
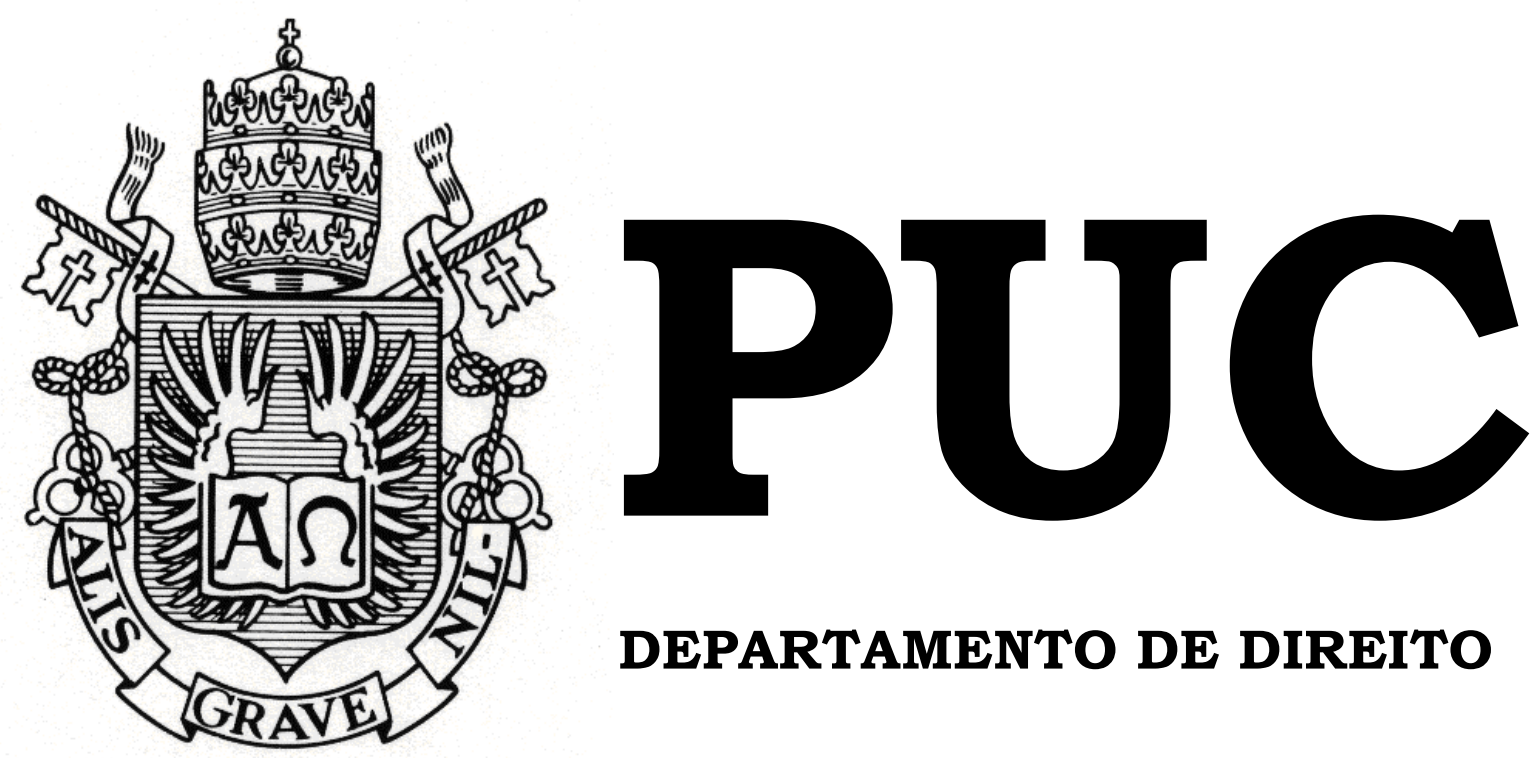

DEPARTAMENTO DE DIREITO

A RESPONSABILIDADE CRIMINAL DECORRENTE DA PRÁTICA DO DISCURSO DE ÓDIO: A LUTA PELO RECONHECIMENTO DA IGUALDADE COMO DIREITO À DIFERENÇA

Por

LUCAS CARVALHO SOARES FREITAS

ORIENTADOR: CARLOS RAYMUNDO CARDOSO

COORIENTADOR: THIAGO RAGONHA VARELA

2018.1

PONTIFÍCIA UNIVERSIDADE CATÓLICA DO RIO DE JANEIRO

RUA MARQUÊS DE SÃO VICENTE, 225 - CEP 22451-900

RIO DE JANEIRO - BRASIL 


\title{
A RESPONSABILIDADE CRIMINAL DECORRENTE DA PRÁTICA DO DISCURSO DE ÓDIO: A LUTA PELO RECONHECIMENTO DA IGUALDADE COMO DIREITO À DIFERENÇA
}

\author{
por \\ LUCAS CARVALHO SOARES FREITAS \\ Monografia \\ apresentada \\ ao \\ Departamento de Direito da Pontificia \\ Universidade Católica do Rio de \\ Janeiro (PUC-Rio) para a obtenção do \\ Título de Bacharel em Direito.
}

Orientador: Carlos Raymundo Cardoso Coorientador: Thiago Ragonha Varela 2018.1 


\section{AGRADECIMENTOS}

Meus profundos agradecimentos à minha família, em especial aos meus pais, que não pouparam esforços para me providenciar o melhor ambiente familiar e educacional possível, um refúgio, repleto de amor e companheirismo, onde sempre pude me sentir acolhido. Foi se espelhando nos imensuráveis esforços despreendidos por eles que ganhei forças para elaborar e concluir este trabalho e espero, um dia, poder retribuir tudo que já fizeram por mim.

Meus eternos agradecimentos também a todos os docentes do curso de Direito da Pontifícia Universidade Católica do Rio de Janeiro, que colaboraram pela construção da minha formação. Em especial, ao meu orientador, Carlos Raymundo Cardoso, a quem tenho profunda admiração e que me impulsionou a empregar o máximo que tenho de mim a fim de produzir o melhor trabalho possível.

E por fim, aos meus amigos, que, mesmo nos momentos mais difíceis, sempre me apoiaram e nunca me deixaram desistir dos meus sonhos. 


\section{RESUMO}

FREITAS, Lucas Carvalho Soares. A Responsabilidade Criminal Decorrente da Prática do Discurso de Ódio - A Luta pelo Reconhecimento da Igualdade como Direito à Diferença. Rio de Janeiro: 2018: 109 p. Monografia de final de curso. Departamento de Direito da Pontifícia Universidade Católica do Rio de Janeiro - PUC-Rio.

O presente trabalho pretende analisar o instituto do discurso de ódio sob a ótica do Direito Penal brasileiro. Em um primeiro momento, busca-se abordar as conceituações e características dessa conduta, para posterior apuração à luz dos direitos constitucionais envolvidos. Depois, investiga-se as leis penais antidiscrminação vigentes no ordenamento jurídico, bem como as interpretações doutrinárias e jurisprudenciais sobre o assunto. Com isso, a monografia visa ilustrar o quadro discrminatário e preconceituoso em que as minorias estigmatizadas são submetidas, a fim de ressaltar a necessidade de resguardar os direitos fundamentais desses grupos vulneráveis e provocar mudanças na realidade social brasileira.

Palavras-Chave: Discurso de Ódio - Hate Speech - Liberdade de Expressão - Igualdade - Dignidade Humana - Racismo - Crimes de Ódio Preconceito - Discriminação 


\section{SUMÁRIO}

INTRODUÇÃ

CAPÍTULO 1 - O DISCURSO DE ÓDIO FRENTE AO PARADIGMA DEMOCRÁTICO.......................................................................................... 11

1.1 A Dimensão Conceitual do Discurso de Ódio....................................... 11

1.2 O Discurso de Ódio na Constituição Brasileira de 1988 ..................... 18

CAPÍTULO 2 - A CRIMINALIZAÇÃO DA DISCRIMINAÇÃO .......33

2.1 A Evolução Histórica do Preconceito e da Discriminação................... 33

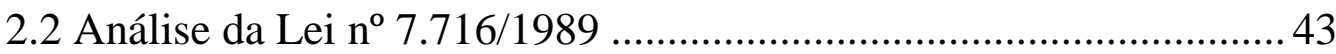

2.3 Os Crimes de Preconceito e Discriminação (ou a tipificação penal do

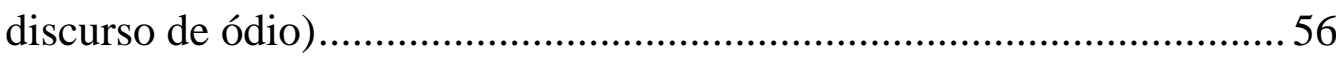

CAPÍTULO 3 - OS DISCURSOS DE ÓDIO DENTRO DA REALIDADE BRASILEIRA .......................................................................... 74

3.1 A Eficácia das Normas Antidiscriminatórias frente à Jurisprudência

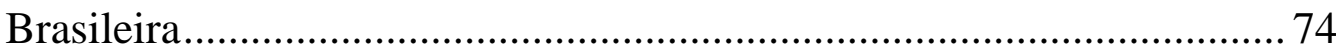

3.2 Análise Empírica dos Crimes de Ódio no Brasil................................ 92

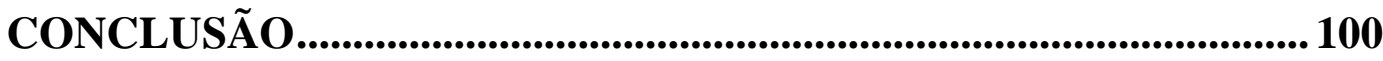

REFERÊNCIAS BIBLIOGRÁFICAS .............................................. 104 


\section{INTRODUÇÃO}

A tolerância ilimitada leva ao desaparecimento da tolerância. Se estendermos a tolerância ilimitada mesmo aos intolerantes, e se não estamos preparados para defender uma sociedade tolerante contra os ataques dos intolerantes, então, os tolerantes serão destruídos, e a tolerância juntamente com eles. Essa formulação não implica que devemos sempre suprimir as filosofias intolerantes. Desde que tenhamos mecanismos para combatê-las com argumentos racionais, e que possamos mantê-las sob controle diante da opinião pública, a supressão seria a opção menos sábia. Entretanto, nós devemos clamar pelo direito até de suprimir os intolerantes, pois facilmente pode acontecer de eles não estarem preparados para discutir no nível de argumentos racionais, refutando qualquer tipo de argumento. Eles podem proibir seus seguidores de escutar qualquer coisa que se pareça com argumentos racionais, e ensiná-los a responder tais argumentos com o uso de seus punhos. Devemos, portanto, em nome da tolerância, reivindicar o direito de não tolerar os intolerantes. Devemos enfatizar que qualquer movimento que pregue a intolerância deva ser considerado fora da lei, e considerar a incitação à intolerância e perseguição devido a ela, como criminal, da mesma forma que fazemos com o assassinato ou com o sequestro ${ }^{1}$.

A citação acima se refere ao paradoxo da tolerância, formulado pelo filósofo Karl Popper, em seu livro A Sociedade Aberta e seus Inimigos, publicado no ano de 1945. Segundo o autor, a tolerância não pode ser ilimitada, caso contrário sofre o risco de ser extinta. Em uma sociedade que prima pela tolerância de discursos e ideias, permitir ideologias intolerantes seria atentar contra o próprio ideal da tolerância. A existência de discursos intolerantes prejudica a criação e difusão de ideologias que pregam a igualdade e respeito ao outro, uma vez que ambos os discursos não conseguem coexistir em um mesmo espaço de debates.

Em outras palavras, para que a tolerância prevaleça, a sociedade deve suprimir as filosofias intolerantes, considerando-as como uma prática criminal. Dessa forma, cria-se um paradoxo: ao mesmo tempo em que a sociedade prega a tolerância, ela também deverá pregar a intolerância em certos casos. Como uma sociedade tolerante, pode, concomitantemente, permitir a intolerância?

\footnotetext{
${ }^{1}$ Popper, Karl. The Open Society and it's Enemies. v. 1. Londom: Butler \& Tanner Ltd., 1945. p. 226. Tradução livre.
} 
O presente trabalho visa abordar exatamente esse questionamento acerca dos limites dados aos discursos intolerantes, denominados como hate speech (traduzido para o português como discurso de ódio), que são caracterizados como uma forma de uso da linguagem para manifestar humilhação, sofrimento moral e vergonha a determinados grupos sociais, historicamente discriminados pela população.

Dessa forma, busca-se analisar a resposta dada ao paradoxo da tolerância pensada por Popper à luz da concepção do Estado Democrático de Direito trazida pela Constituição da República de 1988.

A responsabilidade criminal dos discursos intolerantes foi a solução encontrada por Popper na época em que o discurso de ódio estava em seu ápice, isto é, durante a $2^{\mathrm{a}}$ Guerra Mundial e o Holocausto. Durante esse período, a humanidade vivenciou um dos piores momentos de sua história. Com a propagação do mito da raça ariana, que promovia a ideologia de uma raça superior e a consequente subjugação das demais, a intolerância passou a tomar proporções incontroláveis, sendo concretizada através do extermínio do povo judeu. $\mathrm{O}$ antissemitismo difundido nessa época promoveu a morte milhares de pessoas, causando uma chacina inesquecível na História da Humanidade.

No entanto, seria incorreto pensar que as consequências dos discursos intolerantes se limitam a esse período histórico. Pelo contrário, a sociedade contemporânea vive uma época de exacerbação de discursos negativos, gerando um clima de animosidade que tensiona as coletividades. As mídias digitais universalizaram a comunicação social, possibilitando que discursos com ódio se multipliquem na internet, além de aumentar as violações à privacidade alheia.

Neste sentido, temos a ascensão política de parlamentares como Donald J. Trump, atual presidente dos Estados Unidos da América, e o 
Deputado Federal Jair Bolsonaro, que ganharam visibilidade ao realizarem discursos polêmicos, de cunho racista, sexista, homofóbico e xenofóbico ${ }^{23}$.

Em 2014, durante o período eleitoral, o candidato à Presidência da República Levy Fidelix, se insurgiu contra a possibilidade da união afetiva entre casais do mesmo sexo, incentivando que os heterossexuais, como maioria, enfrentassem a minoria dos homossexuais, fazendo uma clara incitação à violência e discriminação. Por essas razões, o candidato foi condenado a pagar indenização de 1 milhão de reais ao Conselho Nacional de Combate à Discriminação LGBT $^{4}$. No entanto, essa decisão foi reformada pelo TJSP, absolvendo o réu ${ }^{5}$, não havendo ainda trânsito em julgado da lide.

Em 2003, Siegfried Ellwanger, escritor e sócio de uma empresa editora de livros, escreveu, editou e publicou obras de sua autoria e da autoria de outros escritores nacionais e estrangeiros, abordando temas antissemitas. O caso chegou ao Supremo Tribunal Federal, que não concedeu o habeas corpus, mantendo a condenação proferida em segunda instância pela prática do crime de racismo, constituindo um dos leading case no Brasil ${ }^{6}$.

Além da prática dos discursos, estes, uma vez consolidados, podem vir a ultrapassar os limites da fala, concretizando a intolerância em atos de violência contra os grupos minoritários.

Ainda hoje, em países do Oriente Médio, mulheres são privadas de seus direitos básicos fundamentais, sendo executadas pelos mais diversos motivos. Da mesma forma, campos de concentração estão sendo criados na Chechênia, com escopo de erradicar a população LGBT do país.

\footnotetext{
${ }^{2}$ Disponível em: <https://istoe.com.br/nova-era-do-odio-e-da-intolerancia/>. Acesso em: 09 mai. 2018.

${ }^{3}$ Disponível em:

<https://brasil.elpais.com/brasil/2017/11/18/actualidad/1511039404_742600.html>. Acesso em: 09 mai. 2018.

${ }^{4}$ Sigla que engloba o grupo de minorias sexuais, lésbicas, gays, bissexuais e transexuais, entre outros.

${ }^{5}$ TJSP. Apelação n. 10987112920148260100, Rel. Natan Zelinschi de Aruda, 02 fev. 2017.

${ }^{6}$ STF, Habeas Corpus n. 82.424/RS, Rel. Originário Min. Moreira Alves, Pleno, Supremo Tribunal Federal, 19 set. 2003.
} 
Igualmente, a realidade brasileira não se distancia muito disso. São inúmeros os crimes praticados no nosso território, cuja motivação seja baseada unicamente no preconceito. O Brasil traz dados alarmantes acerca da violência doméstica praticada contra as mulheres, vindo a ser condenado pela Corte Interamericana de Direitos Humanos, em razão da sistemática violação aos direitos humanos da mulher.

Um outro exemplo são os números de crimes praticados em razão da homofobia. O Grupo Gay da Bahia (GGB), em seu relatório de 2014, mostrou que uma pessoa LGBT é morta a cada 27 horas no país, tendo totalizado 326 assassinatos de pessoas sexualmente diversas em 2014. Além disso, o relatório demonstra que o Brasil ocupa a posição de primeiro lugar no ranking mundial de assassinatos homo-transfóbicos ${ }^{78}$.

Diante dessa situação, torna-se de suma importância o debate a respeito das leis que visam coibir a prática e difusão dos discursos pautados no ódio, motivo pelo qual este tema foi escolhido como objeto desse trabalho.

Incialmente, no primeiro capítulo, o objetivo é buscar as diferentes conceituações do hate speech, bem como sua evolução histórica no âmbito jurídico ao longo do tempo. Através disso, se tornará mais fácil verificar a distinção entre um discurso de ódio e um mero discurso abarcado pela liberdade de expressão.

Em seguida, o tema será comparado perante a perspectiva constitucional brasileira. Aqui veremos o conflito dos direitos fundamentais à liberdade de expressão e o direito à igualdade e à dignidade humana, positivados pela Constituição da República de 1988.

A finalidade é demonstrar como o discurso de ódio é incompatível com o sistema democrático, uma vez que este promove o direito de toda pessoa ser reconhecida como tal perante a lei, em todos os lugares,

\footnotetext{
7 Disponível em: <https://grupogaydabahia.com.br/2015/01/13/assassinato-de-lgbt-no-brasilrelatorio-2014>. Acesso em: 09 mai. 2018.

8 Disponível em: <https://homofobiamata.files.wordpress.com/2014/03/relatc3b3rio-homocidios2013.pdf>. Acesso em: 09 mai. 2018.
} 
independentemente de cor, etnia, orientação sexual, identidade de gênero, idade, gênero, credo, origem, grau de escolaridade, condição física etc. Afinal de contas, esses são fatores acidentais ou fortuitos que não se erigem como causa de merecimento ou de desmerecimento intrínseco de ninguém. A intolerância e a discriminação ancoradas nesses preconceitos desrespeitam a dignidade humana fundamental de todas as pessoas.

Sendo assim, busca-se asseverar a necessidade da proibição do discurso de ódio frente a ordem democrática estabelecida na Norma Maior vigente.

Uma vez estabelecida a indispensabilidade da vedação à intolerância, o segundo capítulo retratará a forma em que se dará essa proibição. Aqui, o tema será abordado dentro da seara do Direito Penal, justificando a escolha desse direito como o mecanismo necessário e adequado para tutelar essa conduta.

O propósito deste capítulo é estudar como as normas penais vigentes tratam do assunto. Será analisada, principalmente, a Lei $\mathrm{n}$. 7.716/89, acerca da tipificação das condutas oriundas do preconceito em razão da raça, cor, etnia, orientação religiosa e procedência nacional.

A intenção é abordar todas as caraterísticas pertinentes a esses delitos, tais quais os bens jurídicos protegidos, o sujeito ativo, o sujeito passivo, o objeto material, e a tipicidade subjetiva, a fim de tornar clara a importância da criminalização dessas condutas.

Somado a isso, será averiguada a distinção entre o crime de injúria por preconceito, previsto no Código Penal, e o crime de racismo, constatando as diferentes formas em que o discurso de ódio pode se manifestar para atingir bens jurídicos distintos.

No terceiro e último capítulo, será vista a abordagem concreta da temática. Será analisado como a jurisprudência brasileira trata do assunto, estudando, principalmente, o caso Ellwanger, julgado pelo Supremo Tribunal Federal, considerado o leading case no ordenamento jurídico nacional. 
O objetivo deste capítulo é estudar a eficácia e efetividade das normas jurídicas que versam sobre o assunto, bem como sobre a possibilidade de alteração dessas normas, a fim de aumentar seu escopo, alcançando, assim, um maior número de grupos vulneráveis protegidos.

Ademais, será desenvolvido o instituto jurídico dos hate crimes, trazido do direito Norte Americano, que se caracteriza pela prática de crimes comuns (como o homicídio, a lesão corporal, o dano, etc.), quando estes são pautados na intolerância e na discriminação. Busca-se demonstrar, através de dados e estatísticas da realidade brasileira, de que forma o discurso de ódio se concretiza na prática dos mais variados crimes já tipificados na legislação penal, ratificando a grande influência que esse tipo de discurso tem no âmbito criminal. 


\section{CAPÍTULO 1 - O DISCURSO DE ÓDIO FRENTE AO PARADIGMA DEMOCRÁTICO}

\subsection{A Dimensão Conceitual do Discurso de Ódio}

Antes que se possa abordar a problemática central desta monografia, é imprescindível conceituar o instituto jurídico do discurso de ódio, visto que é objeto de grande complexidade. Essa problemática é considerada um dos temas limítrofes do Direito Contemporâneo, posto que, em muitos casos, não se sabe quando se trata de uma ofensa disfarçada de liberdade de expressão ou do verdadeiro uso desse direito.

A ideia do discurso de ódio nasce da utilização de determinadas expressões sob determinadas formas e em variados contextos de tempo e espaço, o que, a princípio, abre espaço para diferentes interpretações. Dessa forma, torna-se mister a criação de um conceito bem elaborado, para que assim seja possível criar mecanismos capazes de identificar corretamente a prática desta conduta e facilitar a distinção com os demais tipos de uso da linguagem.

Ainda hoje, doutrina e jurisprudência brasileiras tratam de buscar uma conceituação profunda para este tema, tentando trazer um consenso em torno de seu conteúdo e entendê-lo de forma detalhada. Mesmo que não haja uniformidade sobre o assunto, através das diferentes concepções apresentadas é possível encontrar elementos em comum que permitem a elaboração de um conceito universal.

Segundo Thiago Anastácio Carcará:

As conceituações apresentadas são unânimes em seus elementos, confluindo para um entendimento majoritário sobre o discurso de ódio, que é a manifestação de pensamento que incita à violência em razão de características 
físicas ou comportamentos sociais, que têm como vítimas preferenciais grupos vulneráveis ${ }^{9}$.

Assim, o autor destaca quatro elementos caracterizadores do discurso de ódio: a manifestação do pensamento; a incitação à violência; características físicas ou comportamentos sociais; e grupos vulneráveis.

A manifestação do pensamento pode ser entendida de duas formas. O discurso de ódio é tanto uma forma de exteriorizar a forma de pensar de um indivíduo, como também é uma forma de limitar essa mesma prática por outrem.

No primeiro caso, a manifestação de pensamento é o exercício puro e simples da liberdade de expressão. O discurso de ódio, como qualquer outra forma de linguagem, é o ato comissivo de fruição de tal direito fundamental. Como o pensamento não é juridicamente relevante, já que em nada interfere na esfera intersubjetiva de outra pessoa, é somente a partir de sua exteriorização que o discurso de ódio/ideias odiosas pode ser considerado como objeto passível de uma tutela jurídica.

No segundo caso, o discurso de ódio pode também ser entendido como uma forma de limitar terceiros de gozar desse mesmo direito. O ambiente democrático é aquele em que permite a coexistência de ideias antagônicas, onde todos possuem a mesma prerrogativa de participação, independentemente de qualquer característica pessoal. Entretanto, diferentemente dos demais discursos, a manifestação odiosa não fomenta o debate, a troca de opiniões divergentes e a circulação de ideologias diversas, como demanda uma verdadeira democracia.

Por ser pautado na dominação e no autoritarismo em detrimento de determinado grupo, essa maneira de usar a fala não visa promover o diálogo com o outro. Pelo contrário, os praticantes desse tipo de discurso almejam silenciar os grupos alvos, com o propósito de fazer prevalecer suas crenças

\footnotetext{
${ }^{9}$ CARCARÁ, Thiago Anastácio. Discurso de ódio no Brasil. Rio de Janeiro: Lumen Juris, 2014. p. 56.
} 
pessoais. Não se constata neste tipo de discurso qualquer abertura para opiniões contrárias.

Neste sentido, Carcará assevera que:

O discurso de ódio, assim como o preconceito e seus ascendentes, discriminação e racismo, são aliados à crença em uma verdade considerada irrefutável e incólume. Desse princípio, o fundamentalista e ortodoxo, propugnam-se a espalhar essa ideia como única fonte real de verdade e que todos devam coadunar com suas reflexões. A maior evidência de que o discurso de ódio é intolerante é a não aceitação de outra corrente à sua tese. A inviabilidade do diálogo é uma das vertentes provocadas pelo discurso de ódio, justamente por ser uma forma de manifestação do pensamento propensa a incitar à violência, e emergida em um furor cego e irreal a ponto de não admitir qualquer outra situação que seja minimamente distante da propugnada ${ }^{10}$.

Ademais, o próprio conteúdo discriminatório e intolerante desse discurso causa um afastamento da vítima perante à sociedade. As humilhações causadas por esses ataques fazem com que o indivíduo se sinta diminuído e rejeitado no meio social em que habita, impedindo que ele se aceite e consequentemente seja aceito pelos demais.

Este sofrimento é também apontado por Daniel Sarmento:

Com efeito, as manifestações de ódio, preconceito e intolerância tendem a provocar uma babel de sentimentos, segundo Mari J. Matsuda, jurista expoente da Critical Race Theory nos Estados Unidos, são frequentemente psicomatizados e podem atingir a dimensão do sofrimento físico. Como tais ataques expressivos são quase sempre dirigidos contra integrantes de grupos vulneráveis, que já enfrentam o estigma social, e têm por isso, com frequência, problemas de autoestima, eles podem desencadear verdadeiras crises de identidade nas suas vítimas, como foi destacado na decisão do já citado caso Regina vs Kegstra proferido pela Suprema Corte do Canadá ${ }^{11}$.

Dessa forma, a prática da manifestação odiosa cria um obstáculo para o exercício pleno da liberdade de expressão de suas vítimas, o que contraria o ideal democrático promovido pela nossa Constituição Federal de 1988.

\footnotetext{
${ }^{10}$ CARCARÁ, 2014, p. 70-71.

${ }^{11}$ SARMENTO, Daniel. Livres e Iguais: Estudos de Direito Constitucional. $1^{\mathrm{a}}$ ed. Rio de Janeiro: Editora Lumen Juris, 2010. p. 246.
} 
Da mesma maneira, o elemento da incitação à violência pode ser entendido sob dois aspectos distintos. Como já demonstrado acima, o discurso de ódio tem como uma de suas consequências principais a lesão moral sofrida pela vítima. $\mathrm{O}$ teor dessa manifestação odiosa causa um grave sofrimento psíquico no ouvinte, que passa por um abalo emocional ao perceber a repulsa que uma parcela da sociedade tem em razão de uma característica pessoal sua, que muitas vezes não pode ser alterada, tal como a orientação sexual, a etnia, o gênero, etc.

Isso faz com que a pessoa passe a ter uma crise de identidade, posto que a maldade contida nas palavras desse discurso gera um sentimento de vergonha e repugnância por essa característica individual, frequentemente causando o isolamento social ou a tentativa de abandono de sua própria natureza.

Não são poucos os casos, por exemplo, de homossexuais que passam uma vida inteira em negação da sua condição ou mentindo para familiares e amigos, com receio de uma possível rejeição. Eles acabam enquadrar-se no padrão heteronormativo, mantendo relações com o sexo oposto na tentativa ineficaz de alterar sua forma de ser, proporcionando uma série de transtornos mentais. Igualmente ocorre com a população afrodescendente, em especial as mulheres, que sofrem críticas e insultos por não se adequarem ao padrão de beleza ocidental, causando uma constante busca por mudanças de suas características físicas naturais, para serem vistas como semelhantes à população caucasiana. $\mathrm{O}$ mesmo sentimento de vergonha pode ser presenciado no caso de pessoas que possuem uma condição econômica de vida mais precária, ocasionando um sentimento de vergonha de seu status social ou do local onde moram, como as comunidades. Ou pessoas que abandonam crenças em determinadas religiões estigmatizadas pela sociedade, como a umbanda e o candomblé, em razão do preconceito em torno dessas crenças.

A intolerância disseminada pelo discurso de ódio ocasiona esses comportamentos sociais, que muitas vezes são internalizados pela vítima 
desde sua infância, fazendo parte de sua formação como indivíduo, que não encontra outra escolha senão adotá-los posteriormente na vida. Assim, essa ideologia cria uma mácula na formação da dignidade humana da vítima, denegrindo sua formação como cidadão e ser humano político.

Esse tipo de discurso, ainda, não se limita à violência moral e pode chegar à violência física contra seus alvos. Como será visto em um tópico específico mais adiante, o Brasil possui altos índices de crimes praticados contra determinados grupos vulneráveis, motivados pelo preconceito e a intolerância. A discriminação propagada por essa manifestação de pensamento pode chegar aos mais elevados níveis de ódio e ira, que serão canalizados para o extermínio do grupo intolerado.

O segundo aspecto da incitação à violência é a busca por adeptos dessa mesma corrente de pensamento. $\mathrm{O}$ discurso de ódio visa não somente atacar a vítima, mas como também disseminar o desprezo, para que outros adotem o mesmo tipo de comportamento. A real demanda desse discurso é tornar sua forma de pensar em uma política de Estado, evoluindo de uma mera manifestação de pensamento para uma ideologia.

Destarte, seria possível espalhar a ideia de supremacia de um grupo em detrimento dos demais grupos daquele Estado, buscando fundamentar a utilização da violência, física ou moral, para causar a submissão e exclusão do grupo discriminado, e posteriormente sua aniquilação e domínio.

Carcará exemplifica esse aspecto com o Holocausto, em que houve a estimativa do extermínio de mais de seis milhões de judeus, que foram mortos apenas por possuírem determinado tipo de religião. Foi a maior atrocidade humana já vista, provocada pela ideologia antissemita como política pelo Estado Nazista, que pregava o discurso de ódio como semente de sua ira ${ }^{12}$.

Também podemos notar esse aspecto no regime de Apartheid ocorrido na África do Sul durante o período de 1948 e 1994, em que uma ideologia de ódio se tornou política governamental, estipulando a

\footnotetext{
${ }^{12}$ CARCARÁ, 2014, p. 86.
} 
segregação racial como uma forma de negar acesso a negros e índios a direitos fundamentais à vida.

Por último, temos os grupos vulneráveis e as características físicas ou comportamentos sociais.

Em relação a vulnerabilidade dos grupos, esta não pode ser entendida apenas como um fator numérico, apesar de poder ser um motivo relevante para determinar se um grupo é vulnerável ou não. Mulheres, por exemplo, ainda podem ser alvo de misoginia e de sexismo, ainda que se encontrem em mesma ou superior quantidade numérica que os homens em certo local, podendo ser consideradas como um grupo vulnerável.

Isto se deve à representação política de certo grupo em seu meio social ser também um fator determinante para a caracterização da vulnerabilidade. Uma reduzida representação política significa uma menor participação no poder e na tomada de decisões daquela sociedade, deixando este segmento populacional à mercê daqueles que se encontram no domínio do convívio social.

Sendo assim, a influência política pode ser usada como instrumento de opressão contra as classes vulneráveis, caso elas possuam certa particularidade social que são contrárias aos valores morais dominantes construídos em determinado local e período histórico.

Essas particularidades são as características físicas ou comportamentos sociais mencionados, que são as razões de perseguição contra os grupos vulneráveis. Pode-se constatar que essa perseguição é sempre originada no preconceito, ou seja, uma construção psicológica resultante da acumulação de opiniões, de estudos, ou conceitos, efetuada sem uma reflexão crítica adequada.

Entende-se por 'preconceito' uma opinião ou um conjunto de opiniões, às vezes até mesmo uma doutrina completa, que é acolhida 'acriticamente' e 'passivamente', na medida em que aceitamos com tanta força que resiste a 
qualquer refutação racional, vale dizer, a qualquer refutação feita com base em argumentos racionais ${ }^{13}$.

Acrescentando a conceituação de Bobbio, Carcará explicita que:

O preconceito negativo constitui-se por juízos provisórios que não foram refutados e esclarecidos durante a história e tornaram-se verdadeiros dogmas. As bases desses juízos provisórios são, em sua grande maioria, constituídas de elementos estereotipados criados pela sociedade em razão de dissonâncias valorativas morais com a integralidade moral de uma determinada sociedade. São movimentos sociais heterogêneos dissociados dessa integralidade que compõe esse juízo provisório que tanto é elemento inicial para a criação do preconceito particularizado, como se transmuta em um estereótipo coletivo, elevando o grau de difusão e aceitação desse juízo perante os membros de determinado grupo e da sociedade ${ }^{14}$.

Então, as perseguições aos grupos vulneráveis são oriundas de certos estigmas e estereótipos construídos ao longo do tempo em relação a determinadas características do ser humano, tais quais a etnia, o gênero, a orientação sexual, a identidade de gênero, a idade, a origem, a orientação religiosa, a condição física ou econômica, entre outros. A História demonstra a discriminação sofrida por determinadas classes em razão de uma dessas características mencionadas. São grupos que foram e ainda são afastados do ambiente democrático e que precisam lutar pelo seu espaço e por direitos igualitários.

Não obstante os grupos vulneráveis serem os principais alvos do discurso de ódio, importa ressaltar que a vulnerabilidade não é requisito essencial para identificar a prática de uma manifestação odiosa. Ainda que bem menos frequente, o discurso de ódio pode ter como alvo grupos não vulneráveis, desde que esteja presente a ofensa à dignidade da pessoa humana. Assim, percebe-se que o ponto limítrofe para identificar a natureza odiosa de determinado discurso é a presença da ofensa à dignidade humana alheia, a intenção de manifestar palavras para humilhar e denegrir o outro.

\footnotetext{
${ }^{13}$ BOBBIO, Norberto. Elogio a serenidade e outros escritos morais. NOGUEIRA, Marco Aurélio (Trad.). 2a ed. São Paulo: UNESP, 2011. p. 103.

${ }^{14}$ CARCARÁ, 2014, p. 95.
} 
Conclui-se que o discurso de ódio pode ser entendido como uma manifestação de pensamento, ou seja, uma exteriorização de ideias odiosas capazes de coibir a liberdade de expressão de terceiros, cujo objetivo principal é incitar à violência, disseminando essa ideologia para captar novos praticantes, para que juntos possam torná-la em política estatal e assim subjugar grupos numérico, político ou historicamente vulneráveis, que sofrem preconceito e discriminação em razão de circunstâncias acidentais ou fortuitas, tais como a etnia, a cor de pele, o gênero, a procedência, a orientação sexual, a identidade de gênero, a orientação religiosa, a idade, condição econômica, a condição física, entre outras, violando gravemente o direito fundamental à dignidade humana.

\subsection{O Discurso de Ódio na Constituição Brasileira de 1988}

Após demonstrar quais são os elementos caracterizadores de uma manifestação odiosa, resta saber qual é o tratamento que nossa Constituição Federal proporciona a esse instituto e entender os motivos que levaram a essa escolha. Para que se possa fazer uma análise crítica a respeito do tratamento do hate speech, antes, torna-se necessário, identificar os direitos fundamentais envolvidos nessa conduta e aborda-los à luz do Direito Constitucional.

Por um lado, a Constituição de 1988 traz como um dos fundamentos principais da República a dignidade da pessoa humana, consoante o Art. $1^{\circ}$, inciso III, CF/88.

Art. $1^{\circ}$ A República Federativa do Brasil, formada pela união indissolúvel dos Estados e Municípios e do Distrito Federal, constitui-se em Estado Democrático de Direito e tem como fundamentos:

III - a dignidade da pessoa humana; 
Nos dizeres de Gilmar Mendes:

É esse princípio que inspira os típicos direitos fundamentais, atendendo à exigência do respeito à vida, à liberdade, à integridade física e íntima de cada ser humano, ao postulado da igualdade em dignidade de todos os homens e à segurança. É o princípio da dignidade humana que demanda fórmulas de limitação do poder, prevenindo o arbítrio e a injustiça. Nessa medida, há de se convir em que 'os direitos fundamentais, ao menos de forma geral, podem ser considerados concretizações das exigências do princípio da dignidade da pessoa humana, ${ }^{15}$.

Sendo assim, será o respeito à dignidade humana que irá direcionar os direitos fundamentais para não só buscar proteger reivindicações que são comuns a todos, como também proteger seres humanos que possuem certas particularidades, que os tornarão merecedores de especial atenção do Direito. É esse princípio que irá consagrar direitos específicos às minorias vulneráveis, já que o homem não é mais visto em abstrato, mas na concretude de suas diversas maneiras de ser estar na sociedade.

Mendes ainda assevera que, por conta do princípio da dignidade humana, o Estado está vinculado ao dever de respeito e proteção do indivíduo contra exposição a ofensas ou humilhações ${ }^{16}$. Dessa forma, veda a discriminação preconceituosa, bem como qualquer tipo de discriminação, posto que seria um atentado contra a dignidade humana.

Além disso, ao determinar os objetivos fundamentais da República, no Art. $3^{\circ}$, o constituinte já rejeita toda e qualquer forma de discriminação, não só a racial:

Art. $3^{\circ}$ Constituem objetivos fundamentais da República Federativa do Brasil:

IV - promover o bem de todos, sem preconceitos de origem, raça, sexo, cor, idade e quaisquer outras formas de discriminação.

O Art. $4^{\circ}$ estabelece como princípios para as relações internacionais a prevalência dos direitos humanos e o repúdio ao racismo, logo, se nossas

\footnotetext{
${ }^{15}$ MENDES, Gilmar Ferreira; BRANCO, Paulo Gustavo Gonet. Curso de Direito Constitucional. $12^{a}$ ed. Re. e atual. São Paulo: Saraiva, 2017. p. 131.

${ }^{16}$ Ibid., p. 348.
} 
relações internacionais são pautadas por esses princípios, não poderíamos permitir condutas contraditórias a eles internamente:

Art. $4^{\circ}$ A República Federativa do Brasil rege-se nas suas relações internacionais pelos seguintes princípios:

II - prevalência dos direitos humanos;

VIII - repúdio ao terrorismo e ao racismo;

Somado a isso, o Art. $5^{\circ}$ estipula as garantias individuais, expressando que todos são iguais perante à Lei. Nas lições de Alexandre de Moraes:

A Constituição Federal de 1988 adotou o princípio da igualdade de direitos, prevendo a igualdade de aptidão, uma igualdade de possibilidades virtuais, ou seja, todos os cidadãos têm o direito de tratamento idêntico pela lei, em consonância com os critérios albergados pelo ordenamento jurídico. Dessa forma, o que se veda são as diferenciações arbitrárias, as discriminações absurdas, pois, o tratamento desigual dos casos desiguais, na medida em que se desigualam, é exigência tradicional do próprio conceito de Justiça, pois o que realmente protege são certas finalidades, somente se tendo por lesado o princípio constitucional quando o elemento discriminador não se encontra a serviço de uma finalidade acolhida pelo direito, sem que se esqueça, porém, como ressalvado por Fábio Konder Comparato, que as chamadas liberdades materiais têm por objetivo a igualdade de condições sociais, meta a ser alcançada, não só por meio de leis, mas também pela aplicação de políticas ou programas de ação estatal ${ }^{17}$.

Portanto, o princípio da igualdade impede as restrições preconceituosas, posto que é incompatível haver igualdade onde há essas discriminações arbitrárias. A igualdade aqui não pode ser vista como meramente formal, ou seja, apenas a igualdade de tratamento perante à Lei, ela deve ser também garantida em seu aspecto material, havendo como finalidade igualar os indivíduos no meio social, na medida de sua desigualdade. Por isso, esse princípio é a base para as políticas afirmativas e

\footnotetext{
${ }^{17}$ MORAES, Alexandre de. Direito Constitucional. 33a ed. rev. e atual. São Paulo: Atlas, 2016. p.
} 48. 
a inserção de medidas repressivas contra a discriminação decorrente do preconceito.

Ainda nos dizeres de Moraes, o princípio da igualdade possui três funções limitadoras: uma relativa ao legislador, que não pode editar normas discriminatórias, excepcionando os casos em que há uma finalidade lícita para isso; outra relativa ao intérprete e a autoridade pública, que não poderão aplicar leis de forma a ensejar uma maior discriminação arbitrária; e a última em relação ao particular, que não poderá praticar condutas discriminatórias, preconceituosas ou racistas, sob pena de responsabilidade penal e civil, nas formas da legislação em vigor ${ }^{18}$. Logo, com esta última finalidade, torna-se clara a vedação a prática do discurso de ódio pelo particular.

No mesmo sentido, Sarmento preleciona que a igualdade tratada na Constituição de 1988 não se limita apenas a atuação estatal perante os cidadãos, se aplicando também às próprias relações entre os indivíduos ou entidades privadas, que não possuem a prerrogativa de discriminar ou desrespeitar terceiros. Para o jurista, isso se dá em virtude da adoção do princípio da eficácia horizontal dos direitos fundamentais pelo ordenamento brasileiro, que diante da ubiquidade, da injustiça e da opressão, procura vincular e obrigar os particulares, ainda que de forma diferenciada, graças a proteção constitucional conferida à autonomia privada ${ }^{19}$.

O princípio da igualdade está positivado no Art. $5^{\circ}$, caput, da $\mathrm{CF} / 88$ :

Art. $5^{\circ}$ Todos são iguais perante a lei, sem distinção de qualquer natureza, garantindo-se aos brasileiros e aos estrangeiros residentes no País a

\footnotetext{
${ }^{18}$ MORAES, 2016, p. 48.

19 SARMENTO, Daniel. A Liberdade de Expressão e Problema do "Hate Speech". p. 47. Disponível em: <http://www.dsarmento.adv.br/content/3-publicacoes/19-a-liberdade-deexpressao-e-o-problema-do-hate-speech/a-liberdade-de-expressao-e-o-problema-do-hate-speechdaniel-sarmento.pdf>. Acesso em: 22 jan. 2018.
} 
inviolabilidade do direito à vida, à liberdade, à igualdade, à segurança e à propriedade, nos termos seguintes: ${ }^{20}$.

Ainda, o inciso III do mesmo artigo proíbe o tratamento desumano e degradante e a discriminação preconceituosa é uma delas, que pode ser conjugado com o inciso XLI, que preconiza que a Lei punirá qualquer discriminação atentatória dos direitos e liberdades fundamentais:

III - ninguém será submetido a tortura nem a tratamento desumano ou degradante;

XLI - a lei punirá qualquer discriminação atentatória dos direitos e liberdades fundamentais;

E por fim, temos a opção do constituinte em tornar o racismo um crime inafiançável e imprescritível, que foi o substrato para a criação da Lei n 7.716/89, que será analisada profundamente no próximo capítulo:

XLII - a prática do racismo constitui crime inafiançável e imprescritível, sujeito à pena de reclusão, nos termos da lei;

Por outro lado, temos o direito à liberdade de expressão, que segundo Samantha Ribeiro Meyer-Pflug:

Se consiste, pois, no direito de cada indivíduo pensar e abraçar as ideias que the aprouver sem sofrer qualquer restrição ou retaliação por parte do Estado. O homem é livre para pensar e manifestar seus pensamentos. É o direito de cada indivíduo de escolher as ideias que quer adotar ou não, de ser livre para decidir e exteriorizar seus pensamentos. O Estado não deve criar obstáculos a essa liberdade ${ }^{21}$.

Dessarte, o direito à liberdade de expressão pode ser visto sob duas dimensões. A interna, ou seja, a autonomia individual de cada um, que possibilita a cada cidadão a liberdade de pensar sem receio de qualquer repressão alheia e de ter acesso as mais variadas ideias, para assim poder

${ }^{20}$ BRASIL. Constituição (1988). Constituição da República Federativa do Brasil. Brasília, DF, Senado, 1998.

${ }^{21}$ MEYER-PFLUG, Samantha Ribeiro. Liberdade de Expressão e discurso de ódio. São Paulo: Revista dos Tribunais, 2009. p. 67. 
formar suas próprias convicções, garantida pelo Art. $5^{\circ}$, inciso VI da Constituição:

VI - é inviolável a liberdade de consciência e de crença, sendo assegurado o livre exercício dos cultos religiosos e garantida, na forma da lei, a proteção aos locais de culto e a suas liturgias;

E a externa, que é a exteriorização desse pensamento, permitindo que todos se expressem sob diferentes maneiras e que possam manifestar o conteúdo que desejar sem a necessidade de uma autorização prévia, positivada pelo Art. $5^{\circ}$, incisos IV, IX e XIV:

IV - é livre a manifestação do pensamento, sendo vedado o anonimato;

IX - é livre a expressão da atividade intelectual, artística, científica e de comunicação, independentemente de censura ou licença;

XIV - é assegurado a todos o acesso à informação e resguardado o sigilo da fonte, quando necessário ao exercício profissional;

Outrossim, a Constituição de 1988 reafirma esse direito no Art. 220, ao garantir mais uma vez a liberdade de manifestação de pensamento e a proibição da censura:

Art. 220. A manifestação do pensamento, a criação, a expressão e a informação, sob qualquer forma, processo ou veículo não sofrerão qualquer restrição, observado o disposto nesta Constituição.

$\S 1^{\circ}$ Nenhuma lei conterá dispositivo que possa constituir embaraço à plena liberdade de informação jornalística em qualquer veículo de comunicação social, observado o disposto no art. $5^{\circ}$, IV, V, X, XIII e XIV.

$\S 2^{\circ}$ É vedada toda e qualquer censura de natureza política, ideológica e artística.

Percebe-se que a nossa constituição deu um grande enfoque a esse direito, tendo em vista que ele é um dos pilares do Estado Democrático de Direito. A liberdade de expressão é um dos instrumentos fundamentais da busca da verdade. É através dessa constante troca de opiniões divergentes e 
fomentação do mercado de ideias que os indivíduos podem tentar alcançar uma melhor ideologia de vida. Além disso, é a partir da liberdade de expressão que se garante a inserção de todos os cidadãos no processo de construção de uma sociedade democrática, visto que ela contribui para a formação da opinião pública e possibilita que todos possam participar efetivamente nos debates políticos.

Ainda, não se pode olvidar o caminho percorrido pela liberdade de expressão no histórico político brasileiro. Instituída inicialmente na Constituição Imperial de 1824, ela já sofreu extrema repressão estatal em dois momentos históricos distintos do nosso país. Primeiro, durante o regime do Estado Novo, em que houve censura prévia da imprensa, livros, cinema, teatro e das transmissões de rádio. E posteriormente, a repressão a esse direito fundamental encontrou seu ápice na Ditadura Militar de 1964, em que qualquer ato de expressão contra o governo era repudiado com violência por parte do Estado. Por isso, hoje há maior preocupação em relação à proteção desse direito.

Entretanto, o direito fundamental à liberdade de expressão não é absoluto. Mesmo que seja extremamente protegido pela Norma Maior vigente ele não pode ser usado para humilhar, difamar ou incitar a violência contra grupos de pessoas, posto que seria uma forma abusiva de usufruir desse direito para prejudicar as demais garantias constitucionais de terceiros.

A própria Constituição já demonstra que esse direito não é absoluto, deixando claro no Art. $5^{\circ}$, inciso IV, que ela não pode ser utilizada de qualquer forma, tanto é que é vedado o anonimato. Ademais, o inciso $\mathrm{V}$ do mesmo artigo dá o direito de resposta para aquele que teve seus direitos atingidos pelo uso abusivo da liberdade de expressão, possibilitando também eventual indenização pelos danos causados, sejam eles materiais ou morais. Isso deve ser somado com a garantia dada pela Constituição aos direitos fundamentais à intimidade, à honra e à vida privada, protegidos pelo inciso $\mathrm{X}$. 
IV - é livre a manifestação do pensamento, sendo vedado o anonimato;

$\mathrm{V}$ - é assegurado o direito de resposta, proporcional ao agravo, além da indenização por dano material, moral ou à imagem;

$\mathrm{X}$ - são invioláveis a intimidade, a vida privada, a honra e a imagem das pessoas, assegurado o direito a indenização pelo dano material ou moral decorrente de sua violação;

A possibilidade de restrição à liberdade de expressão é elucidada também por Sarmento, que acrescenta que:

Há, ademais, outros bens e valores constitucionais com que a liberdade de expressão pode colidir em casos concretos, como o devido processo legal, a proteção à saúde e a própria igualdade. Nada no sistema constitucional brasileiro autoriza a conclusão de que a liberdade de expressão deva sempre prevalecer nestes conflitos ${ }^{22}$.

Mister destacar que existem tratados internacionais que também limitam o uso da liberdade de expressão diante das práticas odiosas. Como exemplo, o Pacto Internacional sobre Direitos Civis e Políticos, ao prever o direito à liberdade de expressão, faz uma ressalva em relação ao uso do hate speech e proíbe expressamente qualquer manifestação odiosa:

Artigo 19

1. ninguém poderá ser molestado por suas opiniões.

2. Toda pessoa terá direito à liberdade de expressão; esse direito incluirá a liberdade de procurar, receber e difundir informações e idéias de qualquer natureza, independentemente de considerações de fronteiras, verbalmente ou por escrito, em forma impressa ou artística, ou por qualquer outro meio de sua escolha.

3. O exercício do direito previsto no parágrafo 2 do presente artigo implicará deveres e responsabilidades especiais. Conseqüentemente, poderá estar sujeito a certas restrições, que devem, entretanto, ser expressamente previstas em lei e que se façam necessárias para:

\footnotetext{
${ }^{22}$ SARMENTO, p. 46, Acesso em: 22 jan. 2018.
} 
a) assegurar o respeito dos direitos e da reputação das demais pessoas;

b) proteger a segurança nacional, a ordem, a saúde ou a moral públicas.

Artigo 20

1. Será proibida por lei qualquer propaganda em favor da guerra.

2. Será proibida por lei qualquer apologia do ódio nacional, racial ou religioso que constitua incitamento à discriminação, à hostilidade ou a violência.

Outrossim, há a Convenção Internacional sobre a Eliminação de Todas as Formas de Discriminação Racial, que, em seu Art. 4º, veda a promoção de propagandas, discursos e atos discriminatórios ou que tenham a incitação à discriminação como um de seus objetivos precípuos:

Artigo 4

Os Estados Membros condenam toda propaganda e todas as organizações que se inspirem em idéias ou teorias baseadas na superioridade de uma raça ou de um grupo de pessoas de uma certa cor ou de uma certa origem étnica ou que pretendam justificar ou encorajar qualquer forma de ódio e de discriminação raciais, e comprometem-se a adotar imediatamente medidas positivas destinadas a eliminar qualquer incitação a uma tal discriminação, ou quaisquer atos de discriminação com este objetivo, tendo em vista os princípios formulados na Declaração Universal dos Direitos do Homem e os direitos expressamente enunciados no artigo $\mathrm{V}$ da presente Convenção, inter alia:

a) A declarar, como delitos puníveis por lei, qualquer difusão de idéias baseadas na superioridade ou ódio raciais, qualquer incitamento à discriminação racial, assim como quaisquer atos de violência ou provocação a tais atos, dirigidos contra qualquer raça ou qualquer grupo de pessoas de outra cor ou de outra origem étnica, como também qualquer assistência prestada a atividades racistas, inclusive seu financiamento.

b) A declarar ilegais e a proibir as organizações, assim como as atividades de propaganda organizada e qualquer outro tipo de atividade de propaganda que incitarem à discriminação racial e que a encorajarem e a declarar delito punível por lei a participação nessas organizações ou nessas atividades.

Apesar de o dispositivo só mencionar a discriminação racial, a Convenção explicita em suas considerações iniciais que seu objetivo é 
erradicar toda e qualquer forma de discriminação preconceituosa, podendo qualquer indivíduo que se encontre nessa situação acionar uma das normas contidas na Convenção.

Igualmente, a Convenção Interamericana de Direitos Humanos também expressa o mesmo tipo de restrição à liberdade de expressão, vedando toda apologia ao ódio contra segmentos estigmatizados:

Artigo 13. Liberdade de pensamento e de expressão.

5. A lei deve proibir toda propaganda a favor da guerra, bem como toda apologia ao ódio nacional, racial ou religioso que constitua incitação à discriminação, à hostilidade, ao crime ou à violência.

Além de limitar a liberdade de expressão, esses tratados internacionais também garantem expressamente os direitos à igualdade e à dignidade humana, a fim de promover o tratamento igualitário entre cidadãos e o respeito às diferenças. Assim, o governo brasileiro, ao ratificar esses tratados, mediante, respectivamente, os Decretos $n^{\circ} 592 / 92,23 / 67$ e 678/92 internaliza essas normas internacionais no nosso ordenamento jurídico e assume um compromisso perante à sociedade internacional de adotar todas as medidas necessárias para repudiar manifestações e práticas pautadas na discriminação.

Dessa forma, resta claro que as normas constitucionais em conjunto com os tratados internacionais ratificados pelo Brasil possibilitam a restrição à liberdade de expressão nos casos do hate speech. $\mathrm{O}$ que falta agora é justificar o porquê dessa proibição.

Diversos autores criticam essa limitação, pois criaria um obstáculo à busca da verdade, isto é, a tentativa de alcançar as melhores ideologias a partir do diálogo de opiniões divergentes. Essa é opinião de filósofo político John Stuart Mill23, grande pensador utilitarista e liberal inglês do século XIX, que expressa que a maior importância da liberdade de expressão se

\footnotetext{
${ }^{23}$ MILL, John Stuart. “On Liberty”. In: American State Papers, Federalist, J.S. Mill: Great Books of the Western World. Chicago: Encyclopaedia Britannica Inc., 1978.
} 
encontrava justamente no interesse da sociedade de ouvir as ideias de cada um de seus membros, ainda que incorretas.

No entanto, o que se esquece é que vivemos em uma sociedade desigual, onde nem todos possuem o mesmo espaço e a mesma força para difundir certas ideologias. Os grupos vulneráveis sempre precisam lutar mais para que suas vozes sejam ouvidas.

Então, o discurso de ódio, sendo uma manifestação que visa diminuir o lugar de fala daqueles que já são marginalizados pelo meio social, em nada contribui para a busca da verdade. Se essa conduta fosse permitida o que aconteceria na verdade seria a exclusão das opiniões de diversos segmentos da sociedade, sendo elas de suma importância para a construção e desenvolvimento dos mais variados tipos de ideias. Consequentemente, somente as ideias dos grupos privilegiados seriam ouvidas, o que macula o ideal de verdade visado por esse e outros autores.

Ademais, por mais que a liberdade de expressão seja um instrumento para a formação da democracia, o discurso de ódio funciona de maneira diametralmente oposta. O hate speech possui a prerrogativa de distanciar os grupos alvos do processo democrático, como já explicitado no tópico anterior. A democracia pressupõe a participação igualitária de seus membros, mas isso não será possível com o discurso de ódio, visto que a desigualdade é um dos requisitos dessa manifestação.

José Emílio Medauar Ommati, explicando a teoria de Ronald Dworkin, suscita que a democracia não se resume a regra da prevalência da maioria. Ela significa o comprometimento entre as mais diferentes pessoas de um círculo social em contribuir para um empreendimento político comum. Tendo em vista que todo meio social é composto por indivíduos das mais diferentes formações, para haver essa contribuição é essencial o respeito à diversidade. Logo, o que representa uma democracia é a mesma 
consideração e respeito por todos que se encontram unidos na construção desse projeto em comum ${ }^{24}$.

Ainda sobre a teoria de Dworkin, Ommati esclarece que a democracia deve ser vista como a associação de seres humanos livres e iguais, separando o que ele chama de democracia associativa em três dimensões:

A primeira dimensão é a da soberania popular, que implica uma relação entre a comunidade ou o povo no seu conjunto e os diferentes funcionários que formam o governo. A democracia exige que o povo governe e não os funcionários. Já a segunda dimensão, é a igualdade dos cidadãos. Essa igualdade exige que os cidadãos participem como iguais. Isso se reflete na ideia de que todas as pessoas devem ter o mesmo impacto com o voto. Por fim, a terceira dimensão da democracia associativa é o discurso democrático. Essa é a mais importante para o presente trabalho. De acordo com Dworkin, se o discurso público está restringindo pela censura, ou fracassa porque as pessoas gritam ou insultam-se mutuamente, então não temos um autogoverno coletivo ${ }^{25}$.

Assim, o autor entende que não há conflito entre liberdade de expressão e igualdade nos casos de hate speech, haja vista que são direitos complementares. Já que a igualdade pressupõe o respeito mútuo entre os cidadãos, ela é necessária para garantir a liberdade de expressão de alguns indivíduos. Em uma sociedade desigual não haverá igual liberdade de expressão para todos, logo nem todas as vozes serão ouvidas, assim, nem todos poderiam usufruir de sua garantia fundamental de se expressar livremente.

Com isso, a teoria de Ommati para a proibição do discurso de ódio se pauta na justificativa de que, para que os cidadãos possam se sentir parceiros desse projeto democrático em comum, eles necessitam de garantias individuais, entre elas o direito de não sofrer discriminação preconceituosa. Ele exemplifica com o nazismo na Alemanha e o Apartheid na África do Sul. Os cidadãos desses países jamais iriam aderir à construção do projeto político de suas sociedades sabendo que seus governantes tinham

\footnotetext{
${ }^{24}$ OMMATI. José Emílio Medauar. Liberdade de Expressão e Discurso de Ódio na Constituição de 1988. Rio de Janeiro: Lumen Juris, 2016. p. 137.

${ }^{25}$ OMMATI, 2016, p. 140-141.
} 
intenção de os subjugar ou os aniquilar, o que desconstrói o ideal democrático pretendido pelo autor.

Ele, então, propõe um meio termo: que o discurso de ódio seja vedado, mas que também não se torne possível a censura prévia desse discurso, visto que a liberdade de expressão impediria isso. Segundo ele, o discurso de ódio só se torna possível no momento em que alcança os debates públicos ou privados. Só assim ele chega a atingir indivíduos e passa a gerar consequências. Antes disso, não há como saber se determinado discurso carrega ideias odiosas capazes de ferir direitos alheios, já que as consequências são exatamente o que caracteriza o hate speech.

Dessa forma, o discurso de ódio não pode ser censurado previamente e deve ser analisado casuisticamente. Uma vez manifestado, será apurada a responsabilidade do autor caso provado publicamente o caráter discriminatório do discurso.

Isso é complementado pela opinião de Daniel Sarmento, que também defende a atuação estatal nesse caso, apontando as possíveis mazelas que a omissão diante dessa conduta poderia causar. Segundo o autor, como o discurso de ódio causa inúmeros danos à dignidade humana de seus alvos, o Estado não pode simplesmente tolerar esse ato. Ele exemplifica com a prática de crimes comuns, dizendo que se fosse o caso de um estupro, jamais iriam pregar a tolerância estatal como resposta adequada a essa conduta, posto que violaria gravemente os direitos fundamentais da vítima. Nesse sentido:

Na verdade, quando o Estado se omite diante de uma manifestação pública de ódio ou desrespeito contra minorias - ou até age para protegê-las, proporcionando, por exemplo, escolta policial para assegurar o exercício da liberdade de expressão de racistas e neonazistas, como tem ocorrido algumas vezes nos Estados Unidos -, o sinal que se transmite para o público e para as vítimas é o de que ele não vê nada de errado na conduta do ofensor. A dor e a sensação de abandono dos alvos destas manifestações tende a ser amplificada, e 
o símbolo que fica - e todos sabemos da importância dos símbolos na vida social - é o de um Estado cúmplice da barbárie ${ }^{26}$.

Corroborando a ideia de Ommati, Sarmento também sugere que o hate speech seja aferido caso a caso, com base na ponderação dos interesses envolvidos, pautada pelo princípio da proporcionalidade. Assim, o intérprete deve almejar satisfazer os melhores interesses no caso em concreto, usando como ponto limítrofe a dignidade da pessoa humana.

Cumpre esclarecer que a liberdade de expressão também não pode ser deixada completamente de lado, pois abriria margem de se criar um outro extremo que seria o regime do politicamente correto. Em uma sociedade repleta de preconceitos como a nossa é normal pressupor discriminações em manifestações em que a intenção não foi propagar o ódio a alguém.

Por conta disso, devemos criar critérios para a ponderação realizada pelo magistrado nos casos de discurso de ódio, tais quais: a forma da manifestação, o meio de propagação utilizado, a quantidade e a idade dos ouvintes, os danos causados às vítimas, a intenção do agente, o motivo da discriminação.

No entanto, Sarmento defende também que certos discursos que contribuem para o debate de ideias devem ser tolerados, exemplificando que não deveria haver responsabilidade se alguém defendesse a exclusão dos direitos da população LGBT ou se alguém defendesse que a raça negra possui QI inferior às demais. Entendo, porém, que isso é completamente contraditório com os motivos expostos para a proibição do discurso de ódio. Tais manifestações são claramente violações ao direito à dignidade humana dos membros desses grupos estigmatizados e visa ao afastamento dos mesmos do espaço democrático. A intenção desses discursos é exatamente diminuir e excluir pessoas da participação política, e não podem, de maneira alguma, ser tolerados pelo Estado.

\footnotetext{
${ }^{26}$ SARMENTO, p. 44, Acesso em: 22 jan. 2018.
} 
Enfim, após a análise das normas e doutrinas relevantes ao assunto, pode-se concluir que a Constituição da República de 1988 optou pela repressão ao discurso de ódio, tendo em vista que atenta contra o regime democrático instituído pela mesma. É uma manifestação que viola gravemente os princípios da igualdade, liberdade de expressão e dignidade humana e em nada contribui para o debate racional de ideias, devendo ser aferido casuisticamente, com base na ponderação de interesses e critérios previamente estabelecidos, gerando responsabilidade para aqueles que o praticam. 


\section{CAPÍTULO 2 - A CRIMINALIZAÇÃO DA DISCRIMINAÇÃO}

\subsection{A Evolução Histórica do Preconceito e da Discriminação}

No primeiro capítulo, vimos que o instituto do discurso de ódio se consiste em uma manifestação de pensamento carregada de ideias preconceituosas acerca de grupos vulneráveis, em que se prima pela dominação e exclusão desses segmentos populacionais e compreendemos as justificativas constitucionais para a sua proibição, tendo a Constituição Federal de 1988 não só adotado a vedação dessa conduta, como também decidido por sua criminalização, à luz do Art. $5^{\circ}$, inciso XLII. Portanto, torna-se mister esclarecer as razões que tornam o Direito Penal o mecanismo jurídico mais adequado para tutelar esse comportamento.

$\mathrm{O}$ ordenamento jurídico brasileiro é separado em diversos ramos que atuam de forma autônoma e independente, sendo o Direito Penal um deles. Entretanto, diferentemente do resto dos âmbitos normativos, o Direito Penal é o único que estipula, como consequência para aqueles que descumprem seus mandamentos, o cumprimento de uma pena. Assim, é nesse ramo que se encontra a consequência jurídica mais grave: a privação da liberdade de um sujeito. Por conta disso, não é qualquer tipo de conduta que será regulamentada por esse ramo, estando o Direito Penal limitado por diversos princípios. Entre eles importa destacar os princípios da lesividade, intervenção mínima, fragmentariedade e subsidiariedade.

Segundo Rogério Greco, são atribuídas quatro funções ao princípio da lesividade: a proibição da incriminação de uma atitude interna; a proibição da incriminação de uma conduta que não exceda o âmbito do próprio autor; a proibição da incriminação de simples estados ou condições existenciais; e a proibição da incriminação de condutas desviadas que não afetam qualquer bem jurídico ${ }^{27}$.

${ }^{27}$ GRECO. Rogério. Curso de Direito Penal Parte Geral. v. 1. Niterói: Editora Impetus, 2013. p. 51. 
Em conformidade com o princípio da lesividade, o princípio da intervenção mínima explicita que somente os bens jurídicos de maior relevo serão regidos pelo Direito Penal. Assim, o Direito Penal só irá intervir quando houver lesão ou perigo de lesão aos bens jurídicos tidos como mais importantes pelo legislador. Ele é a ultima ratio, só poderá ser acionado quando os demais ramos do direito se mostrarem insuficientes para tutelar determinado bem jurídico. Nos ensinamentos de Greco:

\begin{abstract}
As vertentes do princípio da intervenção mínima são, portanto, como que duas faces de uma mesma moeda. De um lado, orientando o legislador na seleção dos bens jurídicos mais importantes e necessários ao convívio em sociedade; de outro, também servindo de norte ao legislador para retirar a proteção do Direito Penal sobre aqueles bens que, no passado, gozavam de especial importância, mas que hoje, com evolução da sociedade, já podem ser satisfatoriamente protegidos pelos demais ramos do ordenamento jurídico ${ }^{28}$.
\end{abstract}

Somado a isso, existem os princípios da fragmentariedade e subsidiariedade que expõem que o Direito Penal não cria tutelas nem bens jurídicos, ele protege bens que já são tutelados por outros ramos do direito. Logo, o direito penal é subsidiário e adicional. É uma proteção a mais que o Estado agrega para os bens jurídicos remanescentes de outros direitos, visando impedir que eles sejam violados.

Dessarte, a fim de entender os motivos que levaram o poder constituinte a criminalizar o racismo e a consequente criação da Lei $n^{\circ}$ 7.716/89, bem como para compreender a existência das demais leis penais especiais que também visam imputar uma responsabilidade criminal em razão da discriminação, é preciso explicar a origem e evolução do preconceito no seio de nossa sociedade.

Estima-se que a segregação entre segmentos populacionais existe desde os primórdios da humanidade. É da natureza do ser humano se agregar em grupos, seja qual for as circunstâncias que os uniram. Essa separação ao longo do tempo resultou na aversão a determinados indivíduos tidos como diferentes a esses grupos. Christiano Jorge Santos aponta o

\footnotetext{
${ }^{28}$ GRECO, 2013, p. 49.
} 
entendimento de que isso decorre do instinto de preservação do ser humano, que por insegurança, tende a se juntar com determinados grupos, rechaçando aqueles que são considerados desiguais. Outro entendimento prelecionado é que o ódio a esses grupos deriva do egoísmo. A repulsa a determinados grupos é usada como motivo ou disfarce para criar conflitos e assim obter algum tipo de vantagem econômica ou política com a vitória sobre essas populações ${ }^{29}$.

Em épocas passadas, o preconceito e a discriminação giravam mais em torno da intolerância religiosa. Posteriormente, a intolerância religiosa ganhou mais força com a propagação do cristianismo e sua consolidação como religião majoritária no mundo ocidental. A Inquisição foi uma demonstração da extrema e violenta perseguição que alguns grupos sofreram por possuírem uma crença diversa ou por praticarem dogmas distintos daqueles defendidos pelos cristãos.

Com o avanço da tecnologia e poder econômico na Europa Colonialista, os países europeus buscaram a resposta para seus conflitos na expansão territorial e na dominação de outros povos. Assim, as populações que mais sofreram com isso foram a indígena e africana, que possuíam menor poder militar, e passaram a ser subjugados e escravizados, principalmente pelos brancos europeus, em virtude do interesse políticoeconômico dos países mais desenvolvidos.

Segundo Santos:

Quanto aos negros africanos, aproximadamente cem milhões foram escravizados e mortos para atender o sistema escravocrata das Américas. (...) A África negra foi condenada à estagnação demográfica e econômica, seus homens, mulheres e crianças foram escravizados, mortos, torturados e violentados culturalmente, para que os portugueses, espanhóis e ingleses pudessem produzir riquezas nas suas colônias. Não houve um genocídio maior na história da humanidade, nem em número nem em brutalidade, do que o

${ }^{29}$ SANTOS. Christiano Jorge. Crimes de Preconceito e de Discriminação. São Paulo: Editora Saraiva, 2010. p. 27. 
cometido contra os negros africanos - incluindo aí os fornos crematórios do nazismo ${ }^{30}$.

No Brasil esse quadro não mudou muito. A sociedade colonial brasileira não admitia o negro como um de seus membros, o enxergando apenas como ferramenta na construção de riquezas, uma mão-de-obra a ser adquirida. A força motora da economia brasileira por muito tempo foi a população negra, que era trazida aos milhares da África como mercadoria, um bem de valor que não possuía características pessoais ou qualquer tipo de cultura, apenas força bruta.

Em relação à população indígena, o povo lusitano inicialmente tinha a intenção de usá-la não só no trabalho, mas como também no processo civilizatório do território brasileiro recém-conquistado. Entretanto, a tentativa de incluir os índios restou ineficaz, uma vez que estes não aceitavam facilmente os costumes e a cultura europeia. O modo de vida dos nativos brasileiros era voltada para pesca e agropecuária sem fins lucrativos, o que ia de encontro com os propósitos lusitanos. Somado a isso, os índios eram preteridos em relação aos negros na escolha da mão-de-obra escrava, posto que os negros possuíam mais afinco e força no trabalho braçal e resistiam menos à escravidão. Isso fez com que o povo indígena passasse a sofrer maior perseguição, resultando no grande extermínio dessa população.

Esse olhar diferenciado que recaia sobre as populações negra e indígena, por efeito das circunstâncias que lhe eram submetidas, gerava um rechaço em relação as suas práticas e costumes como um povo. Os colonizadores não viam essas populações como dignas de terem uma cultura própria e assim repudiavam toda e qualquer manifestação da individualidade desses povos. Com isso, criou-se uma ideia de que a cultura europeia, em especial a lusitana, seria superior às dos povos subjugados. Uma ideologia que defenderia a supremacia de uma raça em detrimento das demais.

\footnotetext{
${ }^{30}$ SANTOS, 2010, p. 28.
} 
Esse tipo de pensamento permaneceu enraizado no território brasileiro por muito tempo. O Brasil foi o último país a abolir oficialmente a escravidão, tendo o feito apenas em 1888. Ainda assim, não foram criadas políticas para incluir os ex-escravos no seio da sociedade, apenas mudando o racismo de dominação para o racismo de exclusão.

As legislações criminais se dirigiam com enfoque, não por acaso, a atos que representavam a existência do negro na sociedade. O Código Criminal do Império, de março de 1830, estabelecia penas severas aos negros em virtude da prática de atos, como a capoeira. De igual modo, o Código Penal de 1890 apenas aboliu a pena de morte, mas estabelecia, entre outros, penas contra a prática da capoeira, mendicância e vadiagem. Com igual restrição, os direitos políticos dos negros foram inicialmente tolhidos pela imposição da alfabetização como elemento para o exercício do direito a votar e ser votado, o que poderia abranger inclusive os brancos, mas a intenção era de isolar politicamente os negros. Ademais, a institucionalização do pensamento escravocrata estava marcada na sociedade e nas repartições públicas ${ }^{31}$.

Somado a isso, com a evolução da ciência, surgiram novas teorias acerca das raças, que contribuíram para a consolidação da ideologia de que existia uma raça superior às demais. Isso fomentou o racismo já crescente nessa época e ajudou a fixar os estereótipos enraizados na mentalidade da população. Além do mais, esses estudos colaboravam para a cisão social entre os povos, na medida em que atribuíam desvios patológicos àqueles que tinham determinadas etnias. As análises criminológicas da época eram pautadas por uma visão determinista, que enxergava a prática dos delitos como oriundas de traços biológicos do ser humano. Assim, os grupos estigmatizados eram tidos como mais propensos à vida criminosa, atribuindo-se a existência de crimes a esses grupos.

Começaram a surgir teses em favor da eugenia, termo que vem da língua grega e significa bem-nascido, buscando proteger uma raça tida como perfeita dos defeitos carregados pelos sujeitos de raças entendidas como inferiores. Essa ideologia passou a ser levada em consideração em políticas públicas, que utilizavam práticas de separação social ou miscigenação, e até mesmo o extermínio das raças consideradas perigosas.

\footnotetext{
${ }^{31}$ CARCARÁ, 2014, p. 34.
} 
No Brasil, havia o mito da democracia racial, que argumentava que não haveria racismo dentro de nossa sociedade, por conta da vasta miscigenação dos povos que aqui habitam. De fato, ainda que rejeitados e perseguidos, os grupos vulneráveis conseguiram disseminar sua cultura e influenciar a formação da matriz étnica e cultural do país. Em virtude disso, a sociedade brasileira foi sendo construída com multiplicidade de costumes, comportamentos e diversidade racial.

Contudo, bastava um olhar mais aprofundado para constatar que a ideologia eugênica também criou raízes no nosso território. Os estereótipos em relação aos grupos vulneráveis ensejavam a ideia de que seria necessária uma política de branqueamento da população. A prática da miscigenação era vista somente como um meio para um fim, que seria a extinção das raças "inferiores" com o processo de branqueamento da população, que tinha previsão para durar de três a quatro séculos. Ademais, como já mencionado, não havia políticas de inclusão para os grupos marginalizados, o que evidenciava a cisão social existente no país.

Outrossim, a eugenia não se limitava a atacar indivíduos em razão da etnia ou cor da pele, mas também abrangia outros grupos estigmatizados. Foram as ideologias eugênicas que deram base para a construção do mito da raça ariana e com ele o surgimento de políticas pautadas no antissemitismo e na xenofobia. Criada na Europa, ela foi disseminada ao redor do mundo e ganhou seu espaço também no território brasileiro. Não obstante o Brasil não ter tido um governo nazista, o regime do Estado Novo instituído por Vargas em 1937 desenvolveu políticas imigratórias antissemitas e xenófobas. Thiago Carcará preleciona que:

Os estudos eugênicos prevalecentes na Europa ainda escoavam em solo brasileiro e muitos intelectuais do governo os aplicavam em políticas públicas, principalmente no que concerne ao controle imigratório antes da segunda guerra mundial. Ademais, o sentimento nacionalista se arraigou no seio da sociedade que se sentia ameaçada com a inserção de imigrantes nos centros urbanos que ascendiam comercialmente, derrubando os brasileiros de seus postos. $\mathrm{O}$ receio de que mais imigrantes adentrassem nos centros urbanos e impedissem o avanço comercial dos brasileiros se aliou à política imigratória, ao pensamento eugênico e à, então realista, inclusão da religião judaica como elemento inerente 
à raça. Por outro lado, o fortalecimento da política antissemita se difundia pela Europa se irradiando numa difusão de perseguições que impeliam os judeus a embaixadas e consulados de outros países em busca de um refúgio, de um lar, sendo o Brasil um excelente lugar para ter como lar, pela sua evolução agrícola, industrial e comercial. (...) O tratamento dispensado aos judeus, intitulados pelo Estado Novo como semitas, coibia a imigração desses por meio de critérios objetivos de concessão de vistos, sendo restritos a turistas, dependendo da procedência e com quantidade limitada. O estereótipo do judeu comunista, raça inferior e que advinha ao país para retirar o emprego do brasileiro estava arraigado no seio político e também na sociedade, ocasionando um elemento de ódio que repercute no século XXI com movimentos neonazistas que difundem o antissemitismo e perseguem judeus ${ }^{32}$.

Assim, as ideologias eugênicas manejaram difundir as ideias odiosas acerca de determinados grupos, em razão da etnia, cor, procedência nacional e orientação religiosa. Porém, estes não foram os únicos grupos a passarem por uma ideologia segregacionista. É importante ressaltar também o histórico da discriminação de outras minorias estigmatizadas que também contribuíram para a formação dos pensamentos e comportamentos que constituem o povo brasileiro.

É gritante a discriminação sofrida pela mulher não só no Brasil como ao redor do mundo. Por muitos séculos, a maior parte do mundo enxergava a mulher como uma propriedade do homem, insuscetível de ter direitos próprios. Primeiro do pai e após o casamento passava a ser propriedade do marido. Caso se tornasse viúva, passaria a ser propriedade de seus irmãos ou outros parentes masculinos. Era impensável existir uma mulher com autonomia, posto que sua existência era reduzida a satisfazer as vontades do homem. Sendo assim, ela era afastada dos ambientes político, trabalhista e social, não the restando outra escolha senão o ambiente doméstico-familiar. Ademais, o controle da mulher estava fortemente ligado a ideia de pureza sexual. A mulher precisava manter sua honra sexual intacta para não envergonhar ser marido e sua família. Por conta disso, era considerada vulnerável, sempre precisando ser protegida da agressão sexual de outros homens. Isso servia de mais um motivo para manter a mulher reclusa ao lar e longe da esfera pública.

\footnotetext{
${ }^{32}$ CARCARÁ, 2014, p. 45-46.
} 
Esse tipo de pensamento se perpetuou ao longo do tempo, dando respaldo as visões machistas e sexistas em torno do gênero feminino atualmente. É com base nisso que hoje há ideologias que dão azo à objetificação das mulheres, ao seu afastamento do espaço político e trabalhista, e que justificam o sentimento de posse que alguns homens têm em relação a suas parceiras.

Um outro grupo vulnerável relevante a ser mencionado é a população homoafetiva. Não obstante ser considerada uma prática comum em tempos antigos, a homossexualidade foi paulatinamente sendo caracterizada como imoral. Em razão de extremismos religiosos propagados pelas religiões dominantes, a prática homossexual passou a ser vista como um pecado. Por muito tempo foi difundida a noção de que a orientação sexual seria uma escolha do indivíduo, que optou por se afastar daquilo que se entendia como a vontade de Deus. Dessa forma, eles eram considerados seres impuros, indignos não só de possuírem direito de se relacionar com quem bem entendem como de possuírem qualquer espécie de direito. Assim, quem tinha orientação sexual diversa da orientação hetero dominante, era marginalizado do espaço social e rechaçado perante os demais.

As mesmas circunstâncias permeiam a discriminação sofrida pelos transgsexuais, apesar de estar em evidência apenas em tempos mais recentes. Cabe esclarecer que identidade de gênero se diferencia de orientação sexual. Enquanto esta se caracteriza pelo gênero no qual um sujeito sente atração sexual ou afeto, aquela significa o gênero no qual a pessoa se identifica, ou seja, representa a visão que a pessoa tem dela mesma. Logo, pode acontecer de um indivíduo nascer biologicamente em um corpo de um gênero específico, mas se identificar com outro gênero, ou com ambos os gêneros, ou até mesmo nenhum dos gêneros. Da mesma forma que o anterior, não pode ser tratado como uma escolha do indivíduo, visto que somente se pode alcançar a felicidade plena com a transição para aquilo que você verdadeiramente é. E igualmente ao anterior, esse grupo 
vulnerável sofre demasiada discriminação, também sendo considerados como seres imorais, perversos, merecedores de exclusão social.

Dessa forma, pode-se constatar que as políticas segregacionistas são partes fundamentais na evolução histórico cultural do nosso país. Políticas essas que visam agrupar os seres humanos em grupos, os separando e os classificando, seja em relação à etnia, cor, procedência nacional, gênero, orientação sexual, orientação religiosa, identidade de gênero, condição econômica ou condição física, idade. É essa espécie de ideologia que busca na ciência, na moral ou na religião elementos que justifiquem a classificação dos indivíduos em castas para assim sobrepor umas em detrimento das outras. Os pensamentos segregacionistas estão tão enraizados na mentalidade do povo brasileiro, que permeiam os juízos ultrageneralizados existentes até hoje. São esses estigmas e estereótipos que dão base ao preconceito e à discriminação que habitam de forma ostensiva no território nacional.

É por conta disso que a Constituição da República de 1988 promove enfaticamente a defesa da isonomia e o combate à discriminação. São esses fatores históricos que dão ensejo à opção do constituinte por criminalizar o racismo. A lei $n^{\circ} 7.716 / 89$ foi criada na tentativa de dar um passo para alterar a realidade discriminatória evidente na nossa Nação e tentar consertar o tratamento que foi dispensado aos grupos vulneráveis por tanto tempo.

Não haveria outro ramo do Direito senão o Direito Penal para tutelar condutas tão nefastas quanto o discurso de ódio e os demais atos e práticas discriminatórios. São manifestações que contaminam o convívio social e maculam a possibilidade de se ter uma vivência pacífica entre todos os grupos de cidadãos que compõem a sociedade.

Essas condutas se coadunam com todos os princípios que regem o Direito Penal. São exteriorizações de pensamento, que excedem o âmbito do próprio autor e lesam bens jurídicos de terceiros, não sendo levada em consideração qualquer característica pessoal do agente, muito pelo 
contrário, são motivadas pelas características pessoais das vítimas. Portanto, está de acordo com as funções do princípio da lesividade expostas por Greco. Ademais, elas ferem bens jurídicos indisponíveis para a construção do Estado Democrático de Direito, que são a igualdade e a dignidade humana. São valores que já são protegidos pelos demais âmbitos do Direito, mas que, devido a gravidade da lesão e a importância desses bens jurídicos, que são inerentes à condição de ser humano, se requer do Estado uma proteção adicional, tornando-se necessária uma resposta mais severa e eficaz. Logo, também estão de acordo com os princípios da intervenção mínima, subsidiariedade e fragmentariedade.

Corroborando esse pensamento, Nucci assevera que:

Discriminar, como regra, significa estabelecer diferença entre seres e coisas, com prejudicialidade para a parte inferiorizada. O termo possui forte carga negativa, inclusive emocional. Discrimina-se o ser humano considerado indesejado em determinado ambiente, por alguma razão. Em alguns casos, sustenta-se haver um motivo de ordem ética para tanto ou até mesmo moral (ex.: pode-se excluir do pessoal convívio social alguém que tenha sido criminalmente condenado - motivo ético? -, ou mesmo a prostituta, pelos seus pretensos maus hábitos - razão de ordem moral?). Pode-se, é verdade, discriminar animais e coisas, mas não seria objeto de tutela penal tal procedimento. Quanto aos seres humanos, a discriminação provoca consequências nefastas, por vezes, extremamente dolorosas, implicando, inclusive, como a História já demonstrou, em perda de milhares de vidas. Por outro lado, qualquer forma discriminatória, em relação ao ser humano, deveria ser coibida com veemência, pelo ordenamento jurídico, em todos os níveis, pois pode gerar lesões tanto físicas quanto morais, provocando um sentimento incalculável de revolta e de injustiça. Cremos que, nesse cenário, o Direito Penal deve estar sempre presente. A discriminação do ser humano, em qualquer nível, é grave o suficiente para justificar e legitimar a intervenção desse ramo jurídico, o mais contundente em matéria de punição ${ }^{33}$.

Dispensar qualquer outra forma de tratamento a essas condutas seria apagar da memória dos povos estigmatizados os atos repulsivos do passado que permitiram e incentivaram o ódio entre iguais por motivos segregacionistas de torpeza inominável. (Nucci, 2009).

\footnotetext{
${ }^{33}$ NUCCI, Guilherme de Souza. Leis Penais e Processuais Comentadas. $4^{\mathrm{a}}$ ed. São Paulo: Revista dos Tribunais, 2009. p. 300.
} 


\title{
2.2 Análise da Lei no 7.716/1989
}

Foram apresentadas as justificativas históricas e culturais que levaram o Poder Constituinte a promover enfaticamente o combate à discriminação, restando agora apurar como a legislação ordinária irá cumprir com os objetivos estabelecidos pela nossa Norma Maior vigente. Torna-se, então, necessário analisar as características da Lei $n^{\circ}$ 7.716/1989, principal mecanismo jurídico de combate à intolerância preconceituosa, que veio regulamentar o Art. 5º inciso XLII, da Constituição Federal de 1988.

Inicialmente, antes da entrada da vigência da Lei $n^{\circ} 7.716 / 1989$ estava em vigor no Brasil a Lei $n^{\circ} 1.390 / 1951$, conhecida como a Lei Afonso Arinos. Foi nomeada dessa forma em homenagem ao deputado mineiro Afonso Arinos de Melo, que redigiu o projeto de lei a partir da seguinte justificativa:

\begin{abstract}
Urge, porém, que o Poder Legislativo adote medidas convenientes para que as conclusões científicas tenham adequada aplicação na política do Governo. As disposições da Constituição Federal e os preceitos dos acordos internacionais de que participamos, referentes ao assunto, ficarão como simples declarações platônicas se a lei ordinária não lhe vier dar forças de regra obrigatória de direito. Por mais que se proclame a inexistência, entre nós do preconceito de raça, a verdade é que ele existe, e com perigosa tendência a se ampliar. (...) é sabido que certas carreiras civis, como o corpo diplomático, estão fechadas aos negros; que a Marinha e a Aeronaútica criam injustificáveis dificuldades ao ingresso de negros nos corpos de oficiais e que outras restrições existem, em vários setores da administração. Quando o Estado, por seus agentes, oferece tal exemplo de odiosa discriminação, vedada pela Lei Magna, não é de se admirar que estabelecimentos comerciais proíbam a entrada de negros nos seus recintos. Nada justifica, pois, que continuemos disfarçadamente a fechar os olhos à prática de atos injustos de discriminação racial que a ciência condena, a justiça repele, a Constituição proíbe, e que podem conduzir a monstruosidade, como os 'pogrooms' hitleristas ou a situações insolúveis como da grande massa negra norte-americana ${ }^{34}$.
\end{abstract}

Foi a primeira legislação brasileira que visava criminalizar as práticas da discriminação preconceituosa. A princípio, só regulamentava as condutas baseadas no preconceito de raça ou cor, sendo posteriormente alterada pela Lei $\mathrm{n}^{\circ} 7.437 / 85$, que incluiu os atos discriminatórios em

\footnotetext{
${ }^{34}$ BRASIL. Diário do Congresso Nacional. 24 ago. 1950. p. 5740.
} 
relação ao sexo ou estado civil, ainda deixando de lado os demais preconceitos existentes no país. Possuía redação semelhante ao da lei atual, no entanto, estipulava as infrações como meras contravenções penais. Em virtude disso, foi uma lei de pouca eficácia no combate à intolerância preconceituosa. Nessa perspectiva, Fabiano Augusto Martins Silveira preleciona:

A referida lei cominava, ainda, as penas de prisão simples, de multa e de perda do cargo público, conforme a natureza da infração, sendo objeto de críticas tanto pela falta de rigor das sanções previstas (em nenhum caso ultrapassavam o limite máximo de um ano), como pela técnica casuística de detalhar situações particularíssimas, o que fez excluir de sua incidência comportamentos impregnados de racismo. Afora o conteúdo simbólico, a Lei Afonso Arinos nunca esteve entre os instrumentos legais mais eficazes; ao contrário, segundo investigações de Peter Eccles, dos três casos levados à Justiça de que se teve notícia, dois resultaram em condenação. Como as contravenções penais são, por natureza, infrações de menor potencial ofensivo, a Lei de 1951, em certo sentido, não se desvia do tradicional gradualismo das leis emancipatórias - o racismo, para ser definido como crime, teve de ser antes contravenção ${ }^{35}$.

Com o advento da Constituição Federal de 1988, o Art. 5 , inciso XLII, estabeleceu o racismo como crime inafiançável e imprescritível. Sendo assim, a Lei Afonso Arinos não pôde ser recepcionada na nova ordem constitucional, uma vez que estipulava as infrações como meras contravenções penais. Surge, então, a necessidade de sua substituição.

Dessa maneira, é criada a Lei $n^{\circ} 7.716 / 89$, também chamada de Lei do Racismo ou de Lei Caó, uma vez que foi proposta pelo deputado Carlos Alberto Caó, o mesmo redator que elaborou o Art. $5^{\circ}$, inciso XLII durante a Assembleia Constituinte de 1988. Primeiramente, a lei almejava incluir a criminalização da discriminação por motivos econômicos, sociais, políticos ou religiosos, não se restringindo ao preconceito relativo à raça ou $\operatorname{cor}^{36}$. Entretanto, o então Presidente da República José Sarney, ao realizar a sanção do projeto, vetou essa norma, bem como as normas que dispunham

\footnotetext{
${ }^{35}$ SILVEIRA, Fabiano Augusto Martins. Da Criminalização do Racismo. Aspectos Jurídicos e Sociocriminológicos. Belo Horizonte: Editora Del Rey, 2007. p. 64-65.

${ }^{36}$ BRASIL. Projeto de Lei n. 668, de 1988., de 14 de dezembro de 2017. Disponível em: $<$ http://mail.camara.rj.gov.br/APL/Legislativos/scpro1720.nsf/249cb321f17965260325775900523 a42/33fe5d166f161e70832581f6006be095?OpenDocument\&Start=1.1.1.5\&Highlight=0,668\%2F2 017>. Acesso em: 14 fev. 2018.
} 
acerca da inaplicabilidade da suspensão condicional da pena, a definição da pena acessória de cassação da autorização de funcionamento do estabelecimento reincidente e a definição do rito sumário, motivando o veto com base na contrariedade ao interesse público, consoante o Art. 66, $\S 1^{\circ}$, $\mathrm{CRFB} / 88$.

Portanto, com o infeliz veto parcial do Presidente José Sarney, ainda que sem justificativa plausível, a Lei $\mathrm{n}^{\circ} 7.716 / 89$ foi promulgada estipulando punição apenas para os crimes de preconceito de raça e de cor. Posteriormente, a Lei foi alterada pelas Leis n. 8.081/90 e n. 8.882/94, que tiveram seus conteúdos sobrepostos pela Lei n ${ }^{\circ}$ 9.459/1997, mudando o Art. $1^{\circ}$ para a seguinte redação: "serão punidos, na forma desta Lei, os crimes resultantes de discriminação ou preconceito de raça, cor, etnia, religião ou procedência nacional".

Mais uma vez o legislador ordinário perdeu a oportunidade de cumprir os reais objetivos da Lei $\mathrm{n}^{\circ} 7.716 / 89$, deixando sem proteção alguns grupos vulneráveis que também são grandes alvos de discriminação preconceituosa. Outrossim, a lei nova falhou em alterar o título da Lei $\mathrm{n}^{\mathrm{o}}$ 7.716/89, que ainda expressa "dos crimes de raça e cor", apesar dos seus tipos penais já abarcarem outras formas de discriminação. Sobre esse tema, Guilherme de Souza Nucci explicita que:

O título desta lei perdeu - e muito - a oportunidade de empreender um autêntico avanço no contexto dos direitos e garantias humanas fundamentais, afinal, a Constituição Federal, assegura a dignidade da pessoa humana (Art. $3^{\circ}$, $1^{\circ}$, III), bem como estabelece como objetivo fundamental da República Federativa do Brasil, dentre outros, 'promover o bem de todos, sem preconceitos de origem de raça, sexo, cor, idade, e quaisquer outras formas de discriminação' (Art. $3^{\circ}, \mathrm{IV}$ ). Portanto, não se poderia intitular a Lei 7.716/89 como aquela que 'define os crimes resultantes de preconceitos de raça ou de cor'. E as inúmeras outras maneiras de externar e fazer valer a discriminação? Valeria, então, titulá-la como sendo a lei que 'define os crimes resultantes de preconceitos de qualquer espécie' ou que 'define os crimes resultantes das variadas formas de discriminação'. Em suma, de maneira mais ampla e menos restrita $^{37}$.

\footnotetext{
${ }^{37}$ NUCCI, 2009, p. 300.
} 
No entanto, para saber a real abrangência da Lei n. 7.716/89 é imprescindível estudar os elementos normativos trazidos pelo artigo $1^{\text {o }}$.

Elementos normativos são aqueles que, inseridos no tipo legal de crime, demandam especial esforço interpretativo. Não é dado, pois, conhecê-los em profundidade pela só expressão literal das palavras. A textualidade é tomada apenas como ponto de partida da interpretação. Há como que uma relação de não-indiferença entre o ledor e o texto legal, de maneira que o conteúdo e o sentido dos elementos normativos não estão encerrados na expressão linguística da norma ${ }^{38}$.

O primeiro elemento normativo a ser analisado é o preconceito. Corroborando o conceito já abordado no primeiro capítulo, Nucci defende que o:

Preconceito é a opinião formada, a respeito de algo ou alguém, sem cautela, de maneira açodada, portanto, sem maiores detalhes ou dados em torno do objeto da análise, levando a julgamento precipitados, invariavelmente injustos, provocadores de aversão a determinadas pessoas ou situações ${ }^{39}$.

Ratificando esse entendimento, Fabio Medina Osório e Jairo Gilberto Schafer iluminam que "o preconceito representa uma ideia estática, abstrata, pré-concebida, traduzindo opinião carregada de intolerância, alicerçada em pontos vedados na legislação repressiva"40.

Dessa maneira, o preconceito é pertencente a esfera interna do indivíduo, uma característica de sua forma de pensar. Como já apurado no tópico passado, o preconceito se origina dos costumes, práticas, ideologias e teorias, em tese científicas, que se perpetuaram ao longo do tempo. Logo, o preconceito por si só não é criminalizável, posto que é juridicamente irrelevante o pensamento de um sujeito. É com a exteriorização do preconceito que a Lei se preocupa. A partir dessa manifestação de pensamento é que se terá uma das formas de discriminação.

\footnotetext{
${ }^{38}$ SILVEIRA, 2007, p. 73.

${ }^{39}$ NUCCI, 2009, p. 301.

40 OSÓRIO, Fábio Medina; SCHAFER, Jairo Gilberto. Dos crimes de discriminação e preconceito: anotações à Lei 8.081, de 21-9-1990. Revista do Tribunais, v. 714, p. 329.
} 
Discriminação é o ato de diferenciar, segregar, separar, pessoas, animais ou objetos. Ela não necessariamente terá conotação negativa. Pode significar diferenciar pessoas em razão de suas qualidades. Ou o caso de políticas públicas afirmativas, que objetivam discriminar pessoas para promover a redução da desigualdade material na sociedade. Assim, temos como exemplos de ações afirmativas que protegem as minorias a proteção constitucional que se dá à mulher no mercado de trabalho (Art. $7^{\circ}, \mathrm{XX}$, CRFB/88), o preenchimento de no mínimo $30 \%$ e no máximo de $70 \%$ que cada partido ou coligação deverá realizar para candidaturas de cada sexo, (Art. 10, $\S 3^{\circ}$, Lei n. 9.504/97), a reserva de percentual de cargos e empregos públicos para pessoas com deficiência (Lei n. 8.112/90), a dedicação especializada para o ensino de pessoas com deficiência (Art. 208, III, CRFB/88), a gratuidade no transporte público urbano para os maiores de 65 anos (Art. 230, $\S 2^{\circ}, \mathrm{CRFB} / 88$ ), e as cotas raciais ou sociais para ingresso nas instituições públicas de ensino ou ingresso em cargos públicos.

Sem embargo, a discriminação combatida pela Lei n. 7.716/89 é aquela caracterizada negativamente. Quem pratica essa forma de discriminação:

\begin{abstract}
Não reconhece as diferenças culturais das diversas etnias que compõem o tecido social, tencionando eliminá-las de forma antidemocrática. A ação discriminatória consiste, assim, na negação dos princípios da igualdade e do pluralismo, mediante a imposição de restrições ou exigências desarrazoadas, como também pelo não reconhecimento ou aniquilação das diferenças ${ }^{41}$.
\end{abstract}

Ela só será penalmente relevante se for carregada de preconceito e isso puder ser verificado no mundo exterior. É somente a discriminação preconceituosa o objeto de tutela da Lei n. 7.716/89, ou seja, a ação ou omissão com intenção de lesar ou gerar ameaça de lesão, ao uso, gozo ou fruição de um bem ou direito de terceiro, sendo esse dolo pautado pelo preconceito de raça, cor, etnia, religião ou procedência nacional.

\footnotetext{
${ }^{41}$ SILVEIRA, 2007, p. 104.
} 
Cor é a pigmentação epidérmica de um ser humano. É um termo infeliz, que segundo Christiano Jorge Santos "é melhor utilizado para a definição cromática de qualquer matéria, do que propriamente de pessoas" 42 . É a diferenciação em razão da tonalidade da pele de alguém, que, com base em uma pesquisa feita pelo Instituto Brasileiro de Geografia e Estatística - IBGE, através da metodologia de auto-identificação, existem 143 variações no Brasil ${ }^{43}$. É um termo pouco preciso e ambíguo, muitas vezes confundido com raça. Geralmente, as raças são divididas entre 5 cores: a branca, a preta, a parda, a amarela (asiáticos) e a vermelha (indígenas). No entanto, raça é um termo muito mais abrangente, como se verá mais abaixo.

Etnia é um agrupamento humano que apresenta homogeneidade cultural, biológica ou linguística. Assim, como o anterior é um termo ambíguo e inexato, também frequentemente confundido com raça. Ainda, segundo Maria de Lourdes Teodoro:

Essa definição de etnia é válida para pouquíssimos grupos populacionais no Brasil. Ela adequa-se, com rigor, a populações indígenas, vivendo nas florestas e em algumas reservas, adequa-se a alguns poucos negros 'remanescentes de quilombos', a alguns grupos de brancos (nas regiões sul e sudeste) a um ou outro grupo asiático, vivendo no norte do País. (...) No Brasil, hoje, ao utilizar a expressão 'grupo étnico' para descrever brancos, negros, indígenas, asiáticos, pardos (todos os mestiços, inclusive os morenos de cabelos lisos e origem negro/indígena), não estamos descrevendo 'grupos biologicamente e culturalmente homogêneos'. Referimo-nos, antes, a grupos cujo discurso faz vínculo social, na defesa de interesses próprios e levando necessariamente em conta suas características raciais predominantes ${ }^{44}$.

Portanto, é um termo pouco útil e sem aplicabilidade prática dentro da realidade brasileira.

Religião é a designação da crença em relação a aspectos da origem do universo. É a forma como um indivíduo exerce sua fé, um suporte de

\footnotetext{
${ }^{42}$ SANTOS, 2010, p. 57.

${ }^{43}$ PETRUCCELLI, José Luis. A cor denominada: um estudo do Suplemento da Pesquisa Mensal de Emprego de julho de 1998. Rio de Janeiro: IBGE, 2000. p. 43-46.

${ }^{44}$ TEODORO, Maria de Lourdes. Elementos básicos das políticas de combate ao racismo brasileiro. In: MUANAGA, Kabengle (Org.). Estratégias e políticas de combate à discriminação racial. São Paulo: EDUSP, 1996. p. 106.
} 
ideias em que ele acredita acerca da humanidade e do mundo. Religião pode ser entendida também como uma organização, uma forma que pessoas se agrupam em razão de uma mesma crença em comum.

Um ponto importante a ser abordado é a possibilidade (ou não) de o ateu sofrer preconceito ou discriminação nos termos da Lei n. 7.716/89. Por um lado, Christiano Jorge Santos acredita que a conduta é atípica, já que para ele religião é a crença necessariamente vinculada à existência de ente ou entes superiores, então, o ateísmo deveria ser considerado apenas uma doutrina filosófica ${ }^{45}$. Por outro lado, Fabiano Augusto Martins Silveira defende que os ímpios ou ateus podem ser sujeitos passivos desses crimes, já que é possível que estes sujeitos sofram preconceito ou discriminação religiosa, graças a sua não opção religiosa ${ }^{46}$.

Sigo o pensamento de Silveira, posto que o ateísmo nada mais é que uma forma de religião, isto é, uma maneira de entender o mundo, que para eles é baseada na não existência de entes superiores.

Procedência nacional é outro termo que abarca opiniões conflitantes acerca de seu significado. Mais uma vez Santos e Silveira possuem ideias opostas sobre o tema.

Silveira preleciona que procedência nacional é sinônimo de xenofobia, que significa aversão a estrangeiros. Tendo em vista a opção do legislador por colocar a palavra "nacional", somente o preconceito ou a discriminação em razão do país de origem de alguém que será objeto de tutela jurídico-penal. Assim, somente seriam crime as condutas praticadas por brasileiro contra estrangeiro, estrangeiro contra brasileiro ou entre estrangeiros $^{47}$.

Noutro giro, Santos argumenta que procedência nacional significa apenas o preconceito derivado de regionalismos dentro do Brasil (discriminação contra nordestinos, gaúchos, etc.). Na visão do autor, o "nacional" significa a proteção ao nacional brasileiro, logo, alguém

\footnotetext{
${ }^{45}$ SANTOS, 2010, p. $84-85$

${ }^{46}$ SILVEIRA, 2007, p. 99.

${ }^{47}$ Ibid. p. $99-103$.
} 
proveniente de alguma localidade do Brasil. Para ele, é essa discriminação que se encontra mais presente no território brasileiro, enquanto a xenofobia não tem a mesma relevância no seio da nossa sociedade ${ }^{48}$.

Compreendo que ambos os pensamentos não são mutuamente exclusivos. Procedência nacional é tanto a origem de nascimento em algum lugar do Brasil como também a origem de nascimento em outro país. Portanto, tanto a xenofobia quanto os regionalismos seriam passiveis de tutela da Lei n. 7.716/89. Não existe diferença significativas entres esses preconceitos a ponto de excluir um deles da proteção do Direito e a Constituição Federal de 1988 repudia qualquer forma de discriminação. Esse também é o entendimento de Guilherme Nucci ${ }^{49}$.

Raça é o termo mais polêmico a ser debatido no âmbito dessa Lei e por isso foi deixado por último. Pouca precisa é a definição desse conceito, gerando inúmeras divergências acerca da sua correta aplicação no Direito. Popularmente, raça é entendida apenas na sua concepção biológica. Desse modo, raça seria a divisão dos seres humanos de acordo com suas características físicas, seus fenótipos, como a cor de pele, cor e tipo de cabelo, tipo de nariz, tipo e cor de olhos, altura e compleição, formato e tamanho dos crânios, etc ${ }^{50}$. Poderia, assim, classificar as raças entre brancas, negras, pardas indígenas, amarelas, etc.

Ela se confundiria então com o significado da palavra cor. Todavia, não faria sentido o legislador escolher utilizar duas palavras com o mesmo sentido, contrariando o princípio integrador do ordenamento jurídico de que não existe palavra ou termo inútil na Lei.

Entretanto, essa conceituação resta superada. Com as recentes pesquisas científicas, já foi comprovado que inexiste tal divisão racial entre os seres humanos. Na realidade, o que existe é só uma raça, que é a humana. Nesses termos, há a pesquisa realizada pela Harvard University:

\footnotetext{
${ }^{48}$ SANTOS, 2010, p. 85-90.

${ }^{49}$ NUCCI, 2009, p. 303.

${ }^{50}$ SANTOS, op. cit., p. 52.
} 
Raça humana. Subdivisão. Inexistência. Com a definição e o mapeamento do genoma humano, cientificamente não existem distinções entre os homens, seja pela segmentação da pele, formato dos olhos, altura, pelos ou por quaisquer outras características físicas, visto que todos se qualificam como espécie humana. Não há diferenças biológicas entre os seres humanos. Na essência são todos iguais ${ }^{51}$.

Essa refutação do conceito antigo de divisão racial fez com que surgissem diversos argumentos em favor da igual inexistência da prática do racismo. Muitos defenderam que não poderia haver discriminação racial, isto é, diferenciar uma raça da outra, se cientificamente só existe uma raça, seria um crime impossível. Porém, essa conclusão é completamente incorreta. Ainda que o ser humano comporte só uma raça, existem diversos fatores que ensejam a sua segregação em grupos. As diferentes características que compõem o ser humano são o real motivo gerador da intolerância preconceituosa.

Nessa mesma esteira, Fabiano Augusto Martins Silveira aponta que além da conceituação biológica de raça existe também a concepção histórica, que inclui a primeira, mas não se limita a ela. $\mathrm{O}$ autor critica o conceito biológico em razão das dificuldades classificatórias, a inexistência de um tipo puro e falta de um consenso a respeito das categoriais raciais. Além disso, ele expõe que não há correlação direta entre os aspectos biológicos e psicológicos do ser humano. Por exemplo, quando se afirma que determinada raça sempre age de uma certa forma ou que atribui conquistas históricas a uma certa raça, nada mais é que uma generalização preconceituosa. Sendo assim, não se pode pressupor nada dos indivíduos agrupados apenas por suas características biológicas, tornando-se uma classificação inútil.

Dessa forma, Silveira identifica o conceito histórico como o mais adequado para definir o termo raça. Para ele:

Na verdade, o que define determinado agrupamento humano como raça não são as qualidades inatas do grupo, se é que as tem, mas a presença de um discurso

51 WILSON, Edward O. On Human Nature. Massachusetts: Harvard University Press Cambridge, 1998. p. 48. 
racializante que permeia as relações intergrupais. Esse discurso é construído historicamente por quem recebe o qualificativo racial, ou por quem o manipula exteriormente (...), ou por ambos. (...) O discurso racializante, pois, pode proliferar-se mesmo quando inexistem claras diferenças físicas entre as parcelas cotejadas, conquanto dissimule, mediante um verniz racial, conflitos subjacentes de outra natureza. Com efeito, o pano de fundo do conceito de raça reuniria situações conflitantes, manifestas em diferentes disputas (daí a complexidade etiológica do racismo), mormente a religiosa, a de classes ou a de culturas. O essencial, portanto, para caracterizar o racismo (e a raça como sua ideia principal), menos do que as diferenças físicas e/ou culturais eventualmente existentes entre agrupamentos humanos, é a presença de um discurso racializante superficial, verificável do ponto de vista político-histórico e dotado de razoável repercussão social. Esse discurso, calçado no preconceito, é que grava grupos como raças, podendo ser reproduzido por falsas teorias, crenças, narrações místicas, propagandas, etc ${ }^{52}$.

Então, para o autor, raça é todo e qualquer grupo que sofre uma estigmatização, por características biológicas e/ou culturais, perceptível e identificável em determinado contexto social. Assim, se em uma sociedade particular brancos e pretos não sofrem nenhum discurso que aponte suas diferenças (sejam elas positivas ou negativas), se são tratados da mesma forma, então eles não poderiam ser considerados raças. Portanto, raça é um conceito localizado no espaço e no tempo, por isso, essa concepção é denominada como concepção histórica.

Já para o mundo jurídico-penal, o termo raça só seria relevante quando permeado pelo preconceito e pela discriminação, dado que também são elementos normativos contidos no Art. $1^{\text {o }}$ da Lei n. 7.716/89. Logo, o autor defende que somente os grupos de indivíduos que sofrem preconceito e discriminação é que podem ser considerados raças para o âmbito da Lei n. $7.716 / 89$.

Esse conceito de raça é corroborado por Lourdes MartínezEzchazábal:

Raça é um conceito fluido e transformante, embora historicamente específico, de modo que seu significado é fruto das teorias, interesses e discursos sociais da época em questão. Daí que raça, como um modo socialmente construído de identificação e diferenciação da espécie humana, possa ser qualificada mediante o uso de inúmeros adjetivos, tais como biológica, histórica, cultural ou social.

\footnotetext{
${ }^{52}$ SILVEIRA, 2007, p. 82-83.
} 
Segundo a época, estes termos, por sua vez, podem assumir outros valores retóricos e/ou conceituais em relação ao substantivo que modificam ${ }^{53}$.

Levando essa linha de pensamento mais adiante, Nucci ratifica esse entendimento do termo raça, argumentando que os grupos que não foram abarcados de forma explícita pela Lei n. 7.716/89 (como mulheres, homossexuais, ateus, etc.), podem ser considerados raça, logo, passíveis de serem sujeitos passivos dos crimes dispostos na mesma. O posicionamento de Nucci é lastreado principalmente pela interpretação dada pelo STF ao termo racismo no julgamento do caso Ellwanger, um caso paradigmático que deu novos rumos a criminalização da discriminação. Com base nesse julgamento, o jurista entende que:

Raça é termo infeliz e ambíguo, pois quer dizer tanto um conjunto de pessoas com os mesmos caracteres somáticos como também um grupo de indivíduos de mesma origem étnica, linguística ou social. Raça, enfim, um grupo de pessoas que comunga de ideais ou comportamentos comuns, ajuntando-se para defendêlos, sem que, necessariamente, constituam um homogêneo conjunto de pessoas fisicamente parecidas. Aliás, assim pensando, homossexuais discriminados podem serem (sic), para os fins de aplicação desta Lei, considerados como grupo racial ${ }^{54}$.

Ao mudar o entendimento do termo raça, muda-se também o entendimento do termo racismo, que possui grande relevo, visto que se encontra presente no Art. $5^{\circ}$, inciso XLII, CRFB/88. Por conta disso, esse inciso também virou alvo de grandes divergências. Muitos doutrinadores entendem que a Constituição, ao utilizar o termo racismo nessa norma, queria coibir apenas as discriminações voltadas para os antigos conceitos de raça (branca, negra, indígena, etc.). Dessa maneira, somente essas práticas preconceituosas seriam inafiançáveis, imprescritíveis e sujeitas à pena de reclusão, como demanda o inciso, discriminando estas das demais condutas tipificadas na Lei $\mathrm{n}^{\circ} 7.716 / 89$.

\footnotetext{
${ }^{53}$ MARTÍNEZ-ECHAZÁBAL. O Culturalismo dos anos 30 no Brasil e na América Latina. Rio de Janeiro: FIOCRUZ/CCB, 1996. p. 112.

${ }^{54}$ NUCCI, 2009, p. 303.
} 
Seguindo sua conceituação acerca do termo raça, Nucci contraria esse posicionamento, asseverando que o termo racismo nada mais é do que o pensamento voltado para a segregação de pessoas:

Constituindo alguns seres superiores, por qualquer pretensa virtude ou qualidade, aleatoriamente eleita, a outros, cultivando-se um objetivo segregacionista, apartando-se a sociedade em camadas e estratos, merecedores de vivência distinta. Racista pode ser tanto o sujeito integrante da maioria de determinado grupo contra qualquer indivíduo componente da minoria existente nessa comunidade, como o integrante da minoria, quando se defronta com alguém considerado da maioria. Se o racismo, como acabamos de expor, é, basicamente, uma mentalidade segregacionista, ele é capaz de percorrer todos os lados dos agrupamentos humanos ${ }^{55}$.

Dessa forma, o autor afirma que a melhor interpretação a ser dada a esse elemento normativo do tipo é aquela conforme à Constituição. A Constituição, em conjunto com diversos tratados internacionais, promove múltiplas previsões e determinações garantistas, buscando efetivar para todos a igualdade e dignidade humana perante à lei, sem qualquer forma de discriminação. Além disso, ele defende que a intenção do constituinte ao criminalizar o racismo era combater as mais variadas formas de preconceito e discriminação.

Então, limitar o sentido do termo racismo a apenas traços do fenótipo do indivíduo seria negar todos esses direitos citados a uma parcela significativa da população, pondo em cheque exatamente os direitos que estão em jogo. O conceito exclusivamente biológico é obsoleto e equivocado, devendo ser atualizado perante as circunstâncias da realidade brasileira contemporânea, através da hermenêutica pautada nos princípios e direitos fundamentais consolidados na Constituição. Para o doutrinador não se trata, portanto, de analogia in malam partem e sim de interpretação conforme os mandamentos constitucionais. Se a Constituição preconiza o combate a intolerância preconceituosa, não podem os aplicadores e operadores do direito se valerem de qualquer meio para obstar esse objetivo almejado constitucionalmente. Dessa maneira, Nucci assevera que é preciso

\footnotetext{
${ }^{55}$ NUCCI, 2009, p. 303.
} 
enxergar a Lei n. 7.716/89 com novos olhos, para que se possa revisá-la e atualizá-la, e com isso, ampliar seu âmbito de aplicação, a fim de tentar extirpar de vez o preconceito e a discriminação no nosso País.

De igual modo, Fabiano Silveira ao criticar a falta de uma terminologia exata ou nomen juris para os crimes da Lei n. 7.716/89, explica que ele emprega os termos "crimes raciais" ou "crimes de racismo" para todos os delitos contidos nesta Lei. Assim, ele demonstra que hoje em dia se tornou inócua a distinção entre racismo e os demais crimes de preconceito e discriminaçãa ${ }^{56}$.

Ainda de acordo com esse entendimento, Uadi Lammêgo Bulos ensina que o racismo é todo e qualquer tratamento discriminador da condição humana em que o agente dilacera a autoestima e o patrimônio moral de uma pessoa ou de um grupo de pessoas, tomando como critérios raça ou cor, pele, sexo, condição econômica, origem, etc ${ }^{57}$.

Ademais, urge destacar que o autor do referido inciso da Constituição é o mesmo autor do projeto de lei que resultou na Lei n. 7.716/89. Em seu projeto de lei para regulamentar e definir o crime de racismo, estava incluso, como já visto, a discriminação, por motivos econômicos, políticos, sociais, religiosos. Entretanto, por conta do veto do Presidente, somente foi sancionado os crimes raciais ou de cor. Em nenhum momento houve diferenciação da prática de racismo com os demais crimes de preconceito e de discriminação. Logo, fica claro que a intenção do constituinte ao criar a norma contida no inciso XLII era de caracterizar as mais variadas formas de discriminação preconceituosa, não só as baseadas em características do fenótipo do ser humano.

Por fim, após a análise de todas essas discussões doutrinárias, podese concluir que a Lei n. 7.716/89 emprega diversos elementos normativos cujos significados são vagos, ambíguos e permeados com enormes divergências. Eles, por si só, são ineficientes dentro do princípio da

\footnotetext{
${ }^{56}$ SILVEIRA, 2007, p. 71-72.

${ }^{57}$ BULOS, Uadi Lammêgo. Constituição Federal anotada. 10a ed. São Paulo: Saraiva, 2012. p. 253.
} 
taxatividade da lei penal, restando ao intérprete buscar a melhor solução para atender os reais propósitos da Lei. O Legislador falhou no seu compromisso com o princípio da legalidade estrita, empregando elementos normativos pouco claros, deixando nas mãos do magistrado o dever de providenciar o real significado dessas expressões. O termo mais polêmico é "raça", tendo em vista a interpretação extensiva proposta por Nucci, que entraria em conflito com o princípio da legalidade. Esse termo será melhor estudado no Capítulo 3 deste trabalho, momento em que será visto o tratamento dispensado pela jurisprudência brasileira acerca dos crimes previstos na Lei Caó.

\subsection{Os Crimes de Preconceito e Discriminação (ou a tipificação penal do discurso de ódio)}

Analisados os aspectos da aplicação da Lei n. 7.716/89, resta apurar a tipificação objetiva do crime de discurso de ódio. Os Arts. $3^{\circ}$ ao 14 desta Lei instituem os delitos de obstar, negar, recusar ou impedir alguém de usufruir um direito legítimo seu, especificando as circunstâncias em que cada conduta pode ocorrer, podendo ser uma limitação laborativa (Arts. $3^{\circ}$, 4 e 13 ), à obtenção de serviços ou bens (Arts. $5^{\circ}, 7^{\circ}, 8^{\circ}, 9^{\circ}$ e 10 ), à livre locomoção (Arts. 11 e 12 e também os Arts. $5^{\circ}, 7^{\circ}, 8^{\circ}, 9^{\circ}$ e 10), educacional (Art. $6^{\circ}$ ) ou à integração familiar e social (Art. 14). Já o Art. 20 estipula uma conduta mais abrangente, que é praticar, incitar ou induzir a discriminação e nela é que está incluído o discurso de ódio. Vejamos:

Art. 20. Praticar, induzir ou incitar a discriminação ou preconceito de raça, cor, etnia, religião ou procedência nacional.

Pena: reclusão de um a três anos e multa.

Praticar a discriminação é realizá-la ou executá-la, podendo ser feita de diversas formas, como excluir, dificultar, atrapalhar, segregar, 
separar, prejudicar, desfavorecer, restringir, desrespeitar, etc. Portanto, é uma expressão com âmbito semântico muito amplo.

Os Arts. $3^{\circ}$ ao 14 trazem definições casuísticas dos crimes de preconceito e discriminação. No entanto, o legislador não pode prever todas as condutas possíveis que o ser humano pode tomar para discriminar alguém em razão do preconceito. Então, para preencher essa lacuna foi criado o Art. 20, que pode ser considerado um dispositivo residual, em que se pretende tipificar condutas que não são as especificadas nos demais artigos da mesma Lei ou em outras legislações penais. É nesse dispositivo que a Lei demonstra sua maior preocupação com a igualdade e pluralidade, não tolerando nenhuma forma de realizar a discriminação preconceituosa.

Não se trata, porém, de uma violação ao princípio da taxatividade da Lei Penal. No caso em tela a norma transfere ao intérprete a função de tipificar a conduta, com base na doutrina e jurisprudência e em elementos não expressamente integrantes do tipo. Essa é a tese de Julio Fabbrini Mirabete, que assevera que nos tipos abertos o resultado é que confere ilicitude a essa conduta, já que ela por si mesma era legítima ${ }^{58}$. Logo, o Art. 20 não pode ser considerado um tipo penal aberto, pois não depende do resultado, sendo a conduta por si mesma um ilícito penal.

Induzir significa inspirar, incutir, arrastar. É criar a ideia em alguém. Já instigar é estimular, açular, mover uma ideia já existente em alguém. Aqui a Lei adotou uma posição preventiva no combate à intolerância, posto que o ato discriminatório não precisa chegar a ocorrer para haver a consumação do delito, podendo ser considerado um crime de perigo abstrato no caso desses dois núcleos. Ainda, ela transformou em crimes autônomos condutas que seriam caracterizadas apenas como uma mera participação em outros crimes, como dispõe o Art. 29 do Código Penal, demonstrando a gravidade do resultado dessas ações.

\footnotetext{
${ }^{58}$ MIRABETE, Julio Fabbrini; FABBRINI, Renato N. Manual de direito penal: parte geral. v. 1. $24^{a}$ ed. São Paulo: atlas, 2001. p. 115.
} 
É um tipo misto alternativo, logo a prática de um dos núcleos é suficiente para caracterizar o delito e se houver a prática de mais de um, em um mesmo contexto fático, também resultará na ocorrência de um só crime, afastando-se o concurso de crimes ou a continuidade delitiva.

O sujeito ativo é qualquer pessoa, já que qualquer indivíduo pode praticar uma das ações descritas no caput.

O sujeito passivo é a pessoa discriminada e/ou a coletividade, tendo em vista que a segregação social por motivos preconceituosos atinge toda a sociedade, não restringindo seus efeitos apenas a um único indivíduo.

Então, esse crime pode ser classificado como crime comum, tanto ativa como passivamente.

Os bens jurídicos tutelados, como já observado, são a igualdade e a dignidade da pessoa humana.

O objeto material é a pessoa ou coletividade discriminada.

É um crime formal. A mera prática de uma das condutas já é suficiente para ocorrer a consumação do delito, sendo desnecessária a verificação de um resultado no mundo exterior, apesar de ele ser possível. Basta, então, a vontade do agente de concretizar o resultado e a prática da ação, e isso por si só já é gerador de um dano em potencial.

Essa vontade do agente é permeada por um elemento subjetivo, que é o dolo direto, consubstanciado na vontade livre e consciente de praticar as condutas descritas no tipo legal. Há também incidência de um especial fim de agir, que está contido no Art. $1^{\circ}$ da Lei n. 7.716/89. Assim, só será crime se a prática, indução ou instigação à discriminação seja pautada no preconceito em razão de uma das características dispostas no referido diploma legal. Por isso, pode-se admitir o dolo eventual nesse delito, mas não se admite a modalidade culposa, valendo também para os demais crimes da mesma Lei.

Além disso, é um crime de forma livre, não existe um meio determinado para se praticar qualquer uma das condutas. Instantâneo, a consumação ocorre em um momento definido. Uni ou plurisubsistente, isto 
é, pode ser praticado por um ou mais atos. Se for plurisubsistente admite-se a tentativa, nos termos do Art. 14, inciso II, do Código Penal.

O parágrafo primeiro estipula uma qualificadora, estabelecendo um novo preceito secundário na norma, a pena de reclusão de 2 a 5 anos:

$\S 1^{\circ}$ Fabricar, comercializar, distribuir ou veicular símbolos, emblemas, ornamentos, distintivos ou propaganda que utilizem a cruz suástica ou gamada, para fins de divulgação do nazismo.

Pena: reclusão de dois a cinco anos e multa.

Fabricar é construir, manufaturar, produzir. Comercializar é vender, comprar, trocar, podendo ser por qualquer pessoa, não só o comerciante. Distribuir é dar, doar, entregar, dispersar. Veicular é propalar, transmitir, difundir. Símbolos são sinais ou elementos gráficos que representam ou designam algo. Emblemas são figuras simbólicas, alegorias, insígnias. Ornamentos são elementos que embelezam algo, aderem a alguma coisa. Distintivos são similares aos anteriores, são sinais, símbolos distintivos que distinguem algum posto. Propaganda é a propagação de ideias, teorias ou princípios. Cruz suástica ou gamada é o símbolo do nazismo.

O nazismo foi uma ideologia adotada como política estatal pela Alemanha em 1933. Era pautada no mito da raça ariana, uma raça tida como superior às demais, o que justificaria o extermínio de outras populações tidas como inferiores. O legislador optou pela tipificação específica deste delito, tendo em vista que diversos grupos foram perseguidos em razão dessa ideologia odiosa. Judeus, ciganos, presos comuns, doentes mentais, homossexuais, padres e clérigos, e pessoas que se opunham ao governo eram mandados aos campos de concentração, resultando na morte de cerca de 11 milhões de pessoas.

Entretanto, a norma falhou em seu âmbito de aplicação. O dispositivo estabelece a qualificadora apenas para o uso da suástica. Assim, aquele que divulgar o nazismo de outras maneiras (imagens de Adolf Hitler, 
por exemplo) não recairá neste tipo, podendo ser enquadrado apenas no caput.

Insta salientar que aqui há uma finalidade específica, que é praticar uma das condutas para fins de divulgação do nazismo. Logo, se alguém fabricar uma suástica para qualquer outro fim a conduta será atípica.

O parágrafo segundo institui outra qualificadora, voltada para o meio de execução do crime contido no caput:

$\S 2^{\circ}$ Se qualquer dos crimes previstos no caput é cometido por intermédio dos meios de comunicação social ou publicação de qualquer natureza:

Pena: reclusão de dois a cinco anos e multa

Meios de comunicação social são:

Os diversos processos e instrumentos utilizados pelo homem para exteriorizar o seu pensamento. Mediante eles são transmitidas ou recebidas mensagens orais e verbais, inclusive o teatro, assim, como jornais livros, revistas, panfletos, rádio, telégrafo, telefone, cinema, e as formas mais modernas de comunicação via satélite e através da informática em plena era eletrônica ${ }^{59}$.

Destarte, a qualificadora inclui as publicações realizadas por meio da internet, espaço muito utilizado atualmente como palco para as mais abjetas manifestações preconceituosas.

Já publicação de qualquer natureza é o material:

Com circulação aberta ao público, comercial ou não. Trata-se de matéria escrita, ilustrada, falada, impressa ou não, tendo em vista a expressão utilizada, destinada a servir de suporte para os verbos do tipo incriminador. Não se trata simplesmente de imprensa, porque esta já foi abrangida na expressão 'meios de comunicação'. Assim, livros, revistas, panfletos, discos, fitas cassete, fitas de vídeo, papéis em geral, discursos públicos, tudo aquilo que serve, em tese, de veículo para uma 'publicação de qualquer natureza'. (...) Admite-se, portanto, enquadrados na expressão 'publicações de qualquer natureza', os chamados discurso públicos, tendo-se em vista a finalidade protetiva da norma penal e a potencial lesividade dessas manifestações. Não raro, os comícios e os discursos

59 PINTO FERREIRA, Luiz. Comentários à constituição brasileira. v. 7. São Paulo: Saraiva, 1995. p. 230. 
aparentemente políticos poderiam refletir doutrina segregacionista ou preconceituosa fundada nos motivos vedados em lei ${ }^{60}$.

Essa também é a opinião de Cristiano Jorge Santos ${ }^{61}$.

Percebe-se que a norma traz meios de execuções bem variados, almejando agravar a situação dos agentes que praticam manifestações odiosas que atinjam ou que poderiam atingir um maior número de pessoas, causando, assim, uma maior proliferação das ideologias de ódio.

Cumpre esclarecer as diferenças existentes entre o delito do Art. 20 da Lei n. 7.716/89 e o crime de injúria preconceituosa, previsto no Art. 140, $\S 3^{\circ}$, do Código Penal, haja vista a frequente confusão que permeia essas infrações.

Art. 140 - Injuriar alguém, ofendendo-lhe a dignidade ou o decoro:

$\S 3^{\circ}$ Se a injúria consiste na utilização de elementos referentes a raça, cor, etnia, religião, origem ou a condição de pessoa idosa ou portadora de deficiência:

Pena - reclusão de um a três anos e multa.

Distintamente dos crimes da Lei n. 7.716/89, o crime de injúria fere a honra subjetiva da vítima. Honra subjetiva é a reputação de um indivíduo, é o sentimento que ele tem de si mesmo. Os delitos de preconceito e discriminação da referida Lei até ofendem esse bem jurídico também, mas apenas de forma secundária, está atrelada a ofensa principal que é dirigida à igualdade, à dignidade humana e à pluralidade. Da mesma forma que afetam de forma paralela diversos outros bens jurídicos, como a paz pública, as relações de consumo e a dignidade do consumidor, a convivência social, o trabalho, entre outros.

Outrossim, o delito de injúria preconceituosa é dirigido a uma única pessoa ou pessoas específicas, enquanto a ofensa contida no Art. 20 é praticada contra uma coletividade, um grupo de pessoas unidas por um

${ }^{60}$ OSÓRIO; SCHAFER, 1990, p. 333.

${ }^{61}$ SANTOS, 2010, p. 128. 
elemento em comum, que é um dos elementos normativos descritos no Art. $1^{\circ}$ da Lei 7.716/89. Desse modo, ainda que a manifestação for falada para uma só pessoa, se o seu conteúdo visa ofender uma coletividade, o crime será o do Art. 20.

Exemplificando, se o agente em um debate acalorado xinga outro de "negro macaco" ele está praticando o crime de injúria qualificada pelo preconceito, posto que possui intenção de ofender apenas aquele sujeito, é uma expressão usada como adjetificação de uma pessoa. Noutro turno, se o mesmo agente na mesma situação expressa que "tinha que ser coisa de preto, oh raça imunda", sua conduta se amolda no tipo do Art. 20 da Lei n. 7.716/89, haja vista a ofensa ser dirigida a um grupo de pessoas, a intenção era de exteriorizar o preconceito contra a população negra.

Importa ressaltar que no delito de injúria o mero uso dos termos "negro", "judeu”, "índio", "viado”, como uma forma de qualificar alguém, já é por si só crime, caso comprovado que essas expressões foram utilizadas com o dolo de ofender a dignidade ou decoro de alguém. Assim, outras circunstâncias também deverão ser verificadas no caso em concreto para averiguar a intenção do autor do crime de ofender a honra de alguém, tais quais o contexto que a expressão foi utilizada, a forma que foi manifestada, a entonação do sujeito, etc.

Sem embargo, no caso do uso de termos como "viado" ou "sapatão" (entre outros), comumente utilizados para ofender indivíduos em razão de sua orientação sexual, o crime será de injúria simples, previsto no Art. 140, caput, Código Penal, dado que o texto da injúria preconceituosa não explicita o preconceito pela orientação sexual, apesar de as condutas serem idênticas às demais formas de preconceito. Dessa forma, percebe-se que, ainda que o legislador tenha ampliado o alcance desse dispositivo em relação aos da lei n. 7.716/89, ele também marginaliza alguns grupos vulneráveis, que ficaram sujeitos ao tratamento mais brando do caput do Art. 140. 
Apesar de possuírem penas idênticas, o crime de injúria preconceituosa é de ação penal pública condicionada à representação da vítima, vide o Art. 145, parágrafo único, do Código Penal. Já os delitos da lei n. 7.716/89 são de ação penal pública incondicionada, uma vez que a Lei não excepciona a regra geral do Art. 100 do Código Penal.

Ainda, caso praticadas as condutas criminosas do Art. 140, $\S 3^{\circ} \mathrm{e}$ do Art. 20 da Lei n. 7.716/89 via a utilização de meio que facilite a divulgação para um grande número de pessoas, a injúria preconceituosa terá apenas uma majoração de um terço de sua pena, à luz do Art. 141, III, Código penal, enquanto o crime de discurso de ódio será qualificado pelo § $2^{\circ}$ do Art. 20, estipulando uma pena mais grave, de dois a cinco anos.

Visto os dois principais delitos sobre o assunto, importa destacar agora as demais leis penais que também criminalizam condutas semelhantes.

Primeiro, temos a própria Lei Afonso Arinos (lei n 1.390/51), já estudada. Com a alteração realizada pela Lei n. 7.437/85, que incluiu aos crimes de preconceito de raça e cor a discriminação baseada em gênero e estado civil, alguns doutrinadores entendem que ela continua vigente, somente para estas duas últimas hipóteses. Como a Constituição optou pela criminalização apenas do racismo, esses autores deduziram que a Lei Afonso Arinos havia sido revogada parcialmente. Somente a parte que versava sobre preconceito de raça e cor havia sido revogada, continuando vigente para as discriminações decorrentes de sexo ou estado civil, haja vista ainda estarem em conformidade com a Constituição.

Esse, porém, não é o entendimento de Guilherme Nucci, que, seguindo sua concepção sobre raça e racismo já suscitada, interpreta que a Lei n. 7.437/85 não pôde ser recepcionada pela Constituição Federal de 1988. Para ele racismo é a exteriorização de qualquer forma de pensamento discriminatório, logo a Constituição determinou que qualquer atitude dessa seria criminalizada com pena de reclusão, tornando inaplicável uma lei que diz que a discriminação por sexo e estado civil teria como consequência 
jurídica a prisão simples. Ademais, para o autor a Lei n. 7.716/89 já abarca as hipóteses de sexo ou estado civil, havendo revogação total da Lei Afonso Arinos com o advento de uma nova lei posterior ${ }^{62}$.

Somado a isso, há o Estatuto da Pessoa com Deficiência, a Lei n. $13.146 / 15$, que visa promover a igualdade de fruição de bens e direitos às pessoas com deficiência, cuja discriminação preconceituosa também pode ser visualizada no contexto social brasileiro. Segundo o Art. $2^{\circ}$ da Lei, pessoas com deficiência são aquelas que têm impedimento de longo prazo de natureza física, intelectual ou sensorial, o qual, em interação com uma ou mais barreiras, pode obstruir sua participação plena e efetiva na sociedade em igualdade de condições com as demais pessoas. Ela institui os delitos contra pessoas com deficiências nos Arts. 88 a 91, destacando-se o Art. 88, que veda a prática do hate speech contra esse grupo de indivíduos:

Art. 88. Praticar, induzir ou incitar discriminação de pessoa em razão de sua deficiência:

Pena - reclusão, de 1 (um) a 3 (três) anos, e multa.

$\S 1^{\circ}$ Aumenta-se a pena em $1 / 3$ (um terço) se a vítima encontrar-se sob cuidado e responsabilidade do agente.

$\S 2^{\circ}$ Se qualquer dos crimes previstos no caput deste artigo é cometido por intermédio de meios de comunicação social ou de publicação de qualquer natureza:

Pena - reclusão, de 2 (dois) a 5 (cinco) anos, e multa.

$\S 3^{\circ}$ Na hipótese do $\S 2^{\mathrm{o}}$ deste artigo, o juiz poderá determinar, ouvido o Ministério Público ou a pedido deste, ainda antes do inquérito policial, sob pena de desobediência:

I - recolhimento ou busca e apreensão dos exemplares do material discriminatório;

II - interdição das respectivas mensagens ou páginas de informação na internet.

\footnotetext{
${ }^{62}$ NUCCI, 2009, p. 300-301.
} 
$\S 4$ o Na hipótese do $\S 2$ o deste artigo, constitui efeito da condenação, após o trânsito em julgado da decisão, a destruição do material apreendido.

Percebe-se que é a mesma redação dada ao Art. 20 e parágrafos seguintes da Lei n. 7.716/89. Muito mais fácil seria então, simplesmente alterar esta lei para que incluíssem também a discriminação contra as pessoas com deficiência, no rol de hipóteses cabíveis do Art. $1^{\circ}$.

Além disso, o Estatuto das Pessoas com Deficiência alterou a Lei n. 7.853/89 (antiga Lei das pessoas com deficiência), no que toca a responsabilidade criminal em razão da discriminação desse segmento populacional. Assim, o Art. $8^{\circ}$ desta Lei atualmente versa:

Art. 8o Constitui crime punível com reclusão de 2 (dois) a 5 (cinco) anos e multa:

I - recusar, cobrar valores adicionais, suspender, procrastinar, cancelar ou fazer cessar inscrição de aluno em estabelecimento de ensino de qualquer curso ou grau, público ou privado, em razão de sua deficiência;

II - obstar inscrição em concurso público ou acesso de alguém a qualquer cargo ou emprego público, em razão de sua deficiência;

III - negar ou obstar emprego, trabalho ou promoção à pessoa em razão de sua deficiência;

IV - recusar, retardar ou dificultar internação ou deixar de prestar assistência médico-hospitalar e ambulatorial à pessoa com deficiência;

V - deixar de cumprir, retardar ou frustrar execução de ordem judicial expedida na ação civil a que alude esta Lei.

VI - recusar, retardar ou omitir dados técnicos indispensáveis à propositura da ação civil pública objeto desta Lei, quando requisitados.

§1ㅇ Se o crime for praticado contra pessoa com deficiência menor de 18 (dezoito) anos, a pena é agravada em 1/3 (um terço).

$\S$ 2을 A pena pela adoção deliberada de critérios subjetivos para indeferimento de inscrição, de aprovação e de cumprimento de estágio probatório em concursos 
públicos não exclui a responsabilidade patrimonial pessoal do administrador público pelos danos causados.

$\S 3^{\circ}$ Incorre nas mesmas penas quem impede ou dificulta o ingresso de pessoa com deficiência em planos privados de assistência à saúde, inclusive com cobrança de valores diferenciados.

§4은 Se o crime for praticado em atendimento de urgência e emergência, a pena é agravada em $1 / 3$ (um terço).

Dessarte, ela impõe pena mais grave a algumas condutas discriminatórias mais relevantes para a realidade das pessoas com deficiência. Possuem redações e casos semelhantes aos Arts. $3^{\circ}$ a 14 da lei n. 7.716/89. Aquelas condutas que não estão dispostas no Art. $8^{\circ}$ podem recair no Art. 88 do Estatuto da Pessoa com Deficiência, que assim como o Art. 20, é residual.

Outra Lei que inclui uma criminalização da propagação do discurso de ódio é o Código de Defesa ao Consumidor, a Lei n. 8.078/90, no seu Art. 67, conjugado com o Art. $37, \S 2^{\mathrm{o}}$ :

Art. 67. Fazer ou promover publicidade que sabe ou deveria saber ser enganosa ou abusiva:

Pena Detenção de três meses a um ano e multa.

Art. 37. É proibida toda publicidade enganosa ou abusiva.

$\S 2^{\circ}$ É abusiva, dentre outras a publicidade discriminatória de qualquer natureza, a que incite à violência, explore o medo ou a superstição, se aproveite da deficiência de julgamento e experiência da criança, desrespeita valores ambientais, ou que seja capaz de induzir o consumidor a se comportar de forma prejudicial ou perigosa à sua saúde ou segurança.

Portanto, as publicidades de caráter odioso, que divulgam ideias de discriminação de qualquer forma, seriam punidas com pena de detenção de três meses a um ano. Christiano Jorge Santos intui que esta norma coexiste com o Art. 20 da Lei n. 7.716/89, ainda que a última também incrimine a 
veiculação de propaganda de caráter discriminatório, entendendo que o crime do Código de Defesa do Consumidor:

É próprio porque cometido pelos profissionais que lidam com a veiculação ou antes com o processo criativo de determinada publicidade, entendida essa como qualquer comunicação ao público que visa chamar a atenção e promover a imagem de produtos e serviços com vistas à sua aquisição ou contratação ${ }^{63}$.

Logo, não há antinomia entre esta norma e as que estão previstas na Lei do Racismo, uma vez que se aplica o princípio da especialidade. O legislador optou por diferenciar essa conduta e lhe impor uma pena menos severa.

Outra norma no mesmo sentido é a Lei n. 12.984/2014 que define o crime de discriminação dos portadores do vírus da imunodeficiência humana (HIV) e doentes de AIDS:

Art. 1ำ Constitui crime punível com reclusão, de 1 (um) a 4 (quatro) anos, e multa, as seguintes condutas discriminatórias contra o portador do HIV e o doente de aids, em razão da sua condição de portador ou de doente:

I - recusar, procrastinar, cancelar ou segregar a inscrição ou impedir que permaneça como aluno em creche ou estabelecimento de ensino de qualquer curso ou grau, público ou privado;

II - negar emprego ou trabalho;

III - exonerar ou demitir de seu cargo ou emprego;

IV - segregar no ambiente de trabalho ou escolar;

V - divulgar a condição do portador do HIV ou de doente de aids, com intuito de ofender-lhe a dignidade;

VI - recusar ou retardar atendimento de saúde.

Há também a Lei n. 9.029/95 que veio proteger o acesso e manutenção de emprego contra a discriminação por motivos de sexo,

\footnotetext{
${ }^{63}$ SANTOS, 2010, p. 77.
} 
origem, raça, cor, estado civil, situação familiar, deficiência, reabilitação profissional, idade, entre outros. Ela proíbe a exigência de atestados de gravidez, esterilização e a adoção por parte do empregador de qualquer medida que vise a indução ou incitamento à esterilização genética ou a promoção do controle de natalidade, nos termos do Art. $2^{\circ}$ :

Art. $2^{\circ}$ Constituem crime as seguintes práticas discriminatórias:

I - a exigência de teste, exame, perícia, laudo, atestado, declaração ou qualquer outro procedimento relativo à esterilização ou a estado de gravidez;

II - a adoção de quaisquer medidas, de iniciativa do empregador, que configurem;

a) indução ou instigamento à esterilização genética;

b) promoção do controle de natalidade, assim não considerado o oferecimento de serviços e de aconselhamento ou planejamento familiar, realizados através de instituições públicas ou privadas, submetidas às normas do Sistema Único de Saúde (SUS).

Pena: detenção de um a dois anos e multa.

Parágrafo único. São sujeitos ativos dos crimes a que se refere este artigo:

I - a pessoa física empregadora;

II - o representante legal do empregador, como definido na legislação trabalhista;

III - o dirigente, direto ou por delegação, de órgãos públicos e entidades das administrações públicas direta, indireta e fundacional de qualquer dos Poderes da União, dos Estados, do Distrito Federal e dos Municípios.

Por fim, há o Estatuto do Idoso (Lei n. 10.741/03), que estabelece o crime de discurso de ódio contra pessoa idosa no Art. 96:

Art. 96. Discriminar pessoa idosa, impedindo ou dificultando seu acesso a operações bancárias, aos meios de transporte, ao direito de contratar ou por 
qualquer outro meio ou instrumento necessário ao exercício da cidadania, por motivo de idade:

Pena - reclusão de 6 (seis) meses a 1 (um) ano e multa.

$\S 1^{\circ} \mathrm{Na}$ mesma pena incorre quem desdenhar, humilhar, menosprezar ou discriminar pessoa idosa, por qualquer motivo.

$\S 2^{2}$ A pena será aumentada de $1 / 3$ (um terço) se a vítima se encontrar sob os cuidados ou responsabilidade do agente.

De primeiro plano já se pode notar uma contradição nesse dispositivo. O caput desta norma tipifica circunstâncias específicas de discriminação contra a pessoa idosa, sendo que o parágrafo primeiro amplia a tipificação para qualquer tipo de discriminação, o que torna o caput desnecessário.

Assim, não obstante a redação ser diferente da Lei n. 7.716/89, a norma em questão cria responsabilidade penal por condutas semelhantes as descritas na Lei, proibindo o discurso e práticas de ódio contra as pessoas maiores de 60 anos. Apesar disso, aqui o legislador optou por estabelecer uma consequência mais branda, mesmo sendo a mesma conduta. Então, se a discriminação for contra pessoa idosa, a pena será de seis meses a um ano, o que torna a infração em crime de menor potencial ofensivo, sujeito a qualquer uma das medidas despenalizadoras da Lei 9.099/95, como a composição civil de danos e a transação penal.

Finalizado o estudo das leis penais sobre o assunto, resta mencionar que existem também normas no âmbito administrativo que visam vedar a discriminação. Há a Lei n. 7.041/15 do Estado do Rio de Janeiro que estabelece penalidades administrativas aos estabelecimentos e agentes públicos que discriminem as pessoas por preconceito de sexo ou orientação sexual:

Art. $2^{\circ}$ - O Poder Executivo, no âmbito de sua competência, penalizará estabelecimento público, comercial e industrial, entidades, representações, associações, fundações, sociedades civis ou de prestação de serviços que, por 
atos de seus proprietários ou prepostos, discriminem pessoas em função de preconceito de sexo e de orientação sexual ou contra elas adotem atos de coação, violência física ou verbal ou omissão de socorro.

Parágrafo único - Entende-se por discriminação:

I - recusar ou impedir o acesso ou a permanência ou negar atendimento nos locais previstos no Artigo $2^{\circ}$ desta Lei bem como impedir a hospedagem em hotel, motel, pensão, estalagem ou qualquer estabelecimento similar;

II - impor tratamento diferenciado ou cobrar preço ou tarifa extra para ingresso ou permanência em recinto público ou particular aberto ao público;

III - impedir acesso ou recusar atendimento ou permanência em estabelecimentos esportivos, sociais, culturais, casas de diversões, clubes sociais, associações, fundações e similares;

IV - recusar, negar, impedir ou dificultar a inscrição ou ingresso de aluno em estabelecimento de ensino público ou privado de qualquer nível;

V - impedir, obstar ou dificultar o acesso de pessoas, devidamente habilitadas a qualquer cargo ou emprego da Administração direta ou indireta, bem como das concessionárias e permissionárias de serviços públicos;

VI - negar, obstar ou dificultar o acesso de pessoas, devidamente habilitadas a qualquer cargo ou emprego em empresa privada;

VII - impedir o acesso ou o uso de transportes públicos, como ônibus, metrô, trens, barcas, catamarãs, táxis, vans e similares;

VIII - negar o acesso, dificultar ou retroceder o atendimento em qualquer hospital, pronto socorro, ambulatório ou em qualquer estabelecimento similar de rede pública ou privada de saúde;

IX - praticar, induzir ou incitar pelos meios de comunicação social a discriminação, preconceito ou prática de atos de violência ou coação contra qualquer pessoa em virtude de preconceito de sexo e de orientação sexual;

$\mathrm{X}$ - obstar a visita íntima, à pessoa privada de liberdade, nacional ou estrangeiro, homem ou mulher, de cônjuge ou outro parceiro, no estabelecimento prisional onde estiver recolhido, em ambiente reservado, cuja privacidade e inviolabilidade sejam assegurados, obedecendo sempre, os parâmetros legais pertinentes à segurança do estabelecimento, nos termos das normas vigentes;

Mais uma vez, nota-se a descrição de condutas semelhante a da Lei n. 7.716/89, porém aqui a norma impõe apenas consequências administrativas para o autor das ações discriminatórias, como advertência, 
multa, suspensão da inscrição estadual por 60 dias e cassação da inscrição estadual.

Também existe a Lei Municipal do Rio de Janeiro n. 2.475/96 que volta estipular sanções administrativas aos atos de discriminação em virtude da orientação sexual.

Enfim, analisadas as normas mais pertinentes sobre o tema, o que se conclui é que a Lei n. 7.716/89, que veio para combater a discriminação de todas as formas, acabou por discriminar uns grupos em relação a outros, abrindo margem para a criação de diversas outras Leis antidiscrminatórias. Com isso, uma mesma conduta é tratada das mais variadas formas, a depender de quem é a vítima. Uma ação discriminatória praticada contra pessoas com deficiência é apenada com pena de reclusão de 2 a 5 anos. Agora, a mesma conduta se praticada em razão da raça, cor, etnia, procedência nacional ou orientação religiosa será apenada com pena de reclusão de 1 a 3 anos. Ainda, seguindo o entendimento de alguns doutrinadores, se for em razão da raça (fenótipo do ser humano), será imprescritível e inafiançável, mesmo que a pena seja menor do que a discriminação contra pessoas com deficiência.

O mesmo acontece com o discurso de ódio. Ele, se praticado contra qualquer um dos acima mencionados tem como consequência pena de reclusão de 1 a 3 anos, podendo ser aumentado para 2 a 5 anos, a depender do meio de execução. Se for praticado contra idoso é crime de menor potencial ofensivo, com pena de reclusão de seis meses a 1 ano, não havendo incidência de nenhuma qualificadora. Se for praticado em razão do sexo e do estado civil será uma simples contravenção penal, tendo como consequência uma pena de prisão simples de 3 meses a 1 ano. E pior, se for em razão da orientação sexual ou identidade de gênero, aí a conduta seria lícita dentro do Direito Penal, não havendo qualquer consequência criminal para quem a pratica.

Apesar das peculiaridades das condições de cada uma das vítimas supramencionadas, a dor sofrida pelo preconceito e discriminação é a 
mesma. Os bens jurídicos violados são os mesmos. A gravidade das condutas é a mesma. Então, qual é a justificativa para essa discriminação?

Já estudamos que os objetivos da Constituição Federal e da Lei n. 7.716/89 eram de promover os ideais da igualdade, do pluralismo e da dignidade humana, vedando a discriminação e permitindo somente as diferenciações positivas que a própria Constituição mesmo possibilita. Sendo assim, o legislador pode optar em diferir as consequências jurídicas de uma norma em razão da vítima, caso haja uma justificativa jurídica plausível. No entanto, essa justificativa não se verifica no caso em tela. Não existe qualquer argumento que justifique tamanha discriminação nas formas de tratamento dispensadas às vítimas desse crime. Não existe defesa que possibilite que determinada pessoa ou grupo de pessoas não receba uma resposta estatal adequada para as violações de seus direitos, somente em razão de circunstâncias acidentais ou fortuitas, como gênero, orientação sexual, idade, identidade de gênero, etc. Qualquer manifestação que permitisse isso seria contrária ao ideal de isonomia promovida pela Norma Maior vigente.

Torna-se, então, necessária uma unificação legislativa, que sistematize a forma de tratamento dado, não só ao discurso de ódio, como também as demais práticas e atos de ódio. Uma única lei que inclua todas as minorias estigmatizadas que são alvos de preconceito e discriminação na sociedade e que trate elas com o mesmo respeito e dignidade. É somente dessa forma que se pode pensar em erradicar de vez o preconceito e a discriminação da nossa sociedade.

Nesse sentido, atualmente tramita o Projeto de Lei n. 122/2006, que visa ampliar o âmbito de incidência dos crimes de racismo e injúria preconceituosa $^{64}$. Inicialmente, o Projeto visava apenas a criminalização da homofobia (Projeto n. 5003/01 da Deputada Iara Bernardi, do Partido dos Trabalhadores). No entanto, esse projeto inicial já sofreu inúmeras

\footnotetext{
${ }^{64}$ Disponível em: <https://www25.senado.leg.br/web/atividade/materias/-/materia/79604>. Acesso em: 11 mai. 2018.
} 
alterações, e hoje almeja incluir nos Arts. $1^{\circ}$ e 20 da Lei 7.716/89 os termos "origem" (ao invés de procedência nacional), "condição de pessoa idosa ou com deficiência", "gênero", "sexo", "orientação sexual" ou "identidade de gênero". Os mesmos termos também são empregados para alterar o Art. $140, \S 3^{\circ}$ do CP.

Contudo, o projeto já tramita há 17 anos no Congresso Nacional sem ainda conseguir sua aprovação. $\mathrm{O}$ projeto tem sido alvo de diversas críticas tais quais: a lei impediria o exercício da liberdade de expressão religiosa $^{65}$, que o grupo dos LGBT estaria sendo extremamente privilegiado, criando uma categoria especial de pessoas ${ }^{66}$, e que seria uma imposição da ideologia gay ${ }^{67}$ ou uma ditadura gay ${ }^{68}$, apesar do projeto de lei não se voltar exclusivamente aos direitos dos LGBT.

O Projeto n. 122 foi anexado junto ao Projeto do Novo Código Penal, o Projeto n. 236/2012 ${ }^{69}$. Este possui no Título XIV (crimes contra os interesses metaindividuais), o Capítulo $\mathrm{V}$ (do racismo e dos crimes resultantes de preconceito e discriminação) em que consta o Art. 472 sobre a prática de racismo. Entretanto, apesar de incluir as expressões propostas pelo PL 122, não há qualquer menção ao tipo penal referente ao Art. 20, nem a qualificadora do $\S 2^{\circ}$, da Lei 7.716/89. Ademais, por algum erro de redação, não há pena estipulada para os crimes dispostos no Art. 472.

\footnotetext{
65 Disponível em: <https://juizofinal.wordpress.com/2011/05/15/pl122-por-que-somos-contra-aessa-maldita-lei/>. Acesso em: 11 mai. 2018.

${ }^{66}$ Disponível em: <http://veja.abril.com.br/blog/reinaldo/geral/o-ai-5-gay-ja-comeca-a-satanizarpessoas-seaprovado-vai-provocar-o-contrario-do-que-pretende-acabara-isolando-os-gays/>. Acesso em: 11 mai. 2018.

${ }^{67}$ Disponível em:

<http://www.camara.leg.br/internet/sitaqweb/textoHTML.asp?etapa=11\&nuSessao=0963/13\&nu Quarto $=0 \&$ nuOrador $=0 \&$ nuInsercao $=0 \&$ dtHorarioQuarto $=14: 00 \& \operatorname{sgFaseSessao}=\& D a t a=10 / 7 / 20$ 13\&txApelido=DIREITOS $\% 20$ HUMANOS\%20E\%20MINORIAS\&txFaseSessao=Audi $\%$ C3\%A Ancia\%20P\%C3\%BAblica\%20Ordin \%C3\%A1ria\&txTipoSessao=\&dtHoraQuarto=14:00\&txEtap a=>. Acesso em: 11 mai. 2018.

68 Disponível em: <http://veja.abril.com.br/noticia/brasil/falta-coragem-para-enfrentar-a-ditaduragay>. Acesso em: 11 mai. 2018.

Disponível em: <http://colunas.revistaepoca.globo.com/guilhermefiuza/2013/06/06/a-ditaduragay/>. Acesso em: 11 mai. 2018.

69 Disponível em: <https://www25.senado.leg.br/web/atividade/materias/-/materia/106404>. Acesso em: 11 mai. 2018.
} 


\section{CAPÍTULO 3 - OS DISCURSOS DE ÓDIO DENTRO DA REALIDADE BRASILEIRA}

\subsection{A Eficácia das Normas Antidiscriminatórias frente à Jurisprudência Brasileira}

Nos capítulos anteriores foi analisado como funciona na teoria as normas antidiscriminatórias dentro dos âmbitos constitucional e penal. Agora, resta apurar sua aplicação na prática. Torna-se de suma importância estudar o grau de aplicabilidade dos dispositivos em questão e verificar qual é o entendimento jurisprudencial majoritário acerca das suas hipóteses de cabimento. Sendo assim, este capítulo pretende averiguar a eficácia desses preceitos legais, investigando a aplicabilidade e a hermenêutica dispensada pela jurisprudência nacional.

O precedente mais importante sobre o tema é o HC 82.424/RS, julgado pelo Supremo Tribunal Federal em 2004, sendo considerado o leading case sobre o crime de racismo no Brasil ${ }^{70}$. O Habeas Corpus foi impetrado por Siegfried Ellwanger após ter sido condenado a dois anos de reclusão, com suspensão condicional da pena pelo prazo de quatro anos, por ter editado, distribuído e vendido ao público obras literárias de sua autoria e de autoria de autores nacionais e estrangeiros, que disseminavam o antissemitismo. Os livros, entre outras coisas, almejavam realizar uma revisão histórica do Holocausto, negando fatos históricos relacionados à perseguição dos judeus. Eles abordavam e sustentavam mensagens antissemitas, racistas e discriminatórias, procurando com isso incitar e induzir a discriminação racial, semeando em seus leitores sentimentos de ódio, desprezo e preconceito contra o povo judeu. Portanto, a conduta se amolda no Art. 20, $\S 2^{\circ}$ da Lei n. 7.716/89.

\footnotetext{
70 STF, Habeas Corpus n. 82.424/RS, Rel. Originário Min. Moreira Alves, Pleno, Supremo Tribunal Federal, 19 set. 2003.
} 
Ellwanger foi absolvido pelo juízo de primeira instância, porém sua sentença foi reformada pelo Tribunal de Justiça do Rio Grande de Sul, que foi confirmada pelo Superior Tribunal de Justiça. Com isso, o réu impetrou o HC n. 82.424 ao STF, utilizando-se como único argumento a ocorrência da prescrição do delito, uma vez que a cláusula de imprescritibilidade imposta pelo Art. $5^{\circ}$, inciso XLII, CRFB/88, incorreria somente na hipótese de racismo. Assim, a defesa argumenta que o réu havia praticado "apenas" a discriminação por motivos antissemitas, não estando esta hipótese incluída no termo racismo, que significaria somente as discriminações por características do fenótipo do ser humano (conceito biológico já visto). Portanto, restou ao STF se debruçar sobre o verdadeiro significado dos termos racismo e raça e quais são seus âmbitos de aplicação.

O julgamento foi levado ao Plenário do Supremo que decidiu, por maioria, negar a concessão do habeas corpus. Foram utilizados fatos históricos para demonstrar a gravidade da perseguição aos judeus ao longo do tempo. Em razão disso, entenderam que a exegese estrita do termo racismo não seria a mais correta a ser aplicada, dado que resultaria na omissão do Estado em impedir essa grave perseguição sofrida pelos judeus e demais segmentos populacionais marginalizados.

A hermenêutica correta seria aquela pautada em conformidade com os demais preceitos constitucionais, não podendo resumir conceito do termo raça a sua concepção biológica. Para o Supremo, o verdadeiro significado da palavra racismo é a criação de uma valoração negativa de certo grupo humano, tendo como substrato características socialmente semelhantes, de modo a configurar uma raça distinta à qual se deve dispensar tratamento desigual ao da dominante. Portanto, a divisão racial não decorre de fatores científicos, já que estes já se encontram superados, e sim de processos históricos, políticos e sociais, e são eles que deverão ser considerados na aplicação do direito, o que justifica a aplicação do inciso XLII ao caso em questão. 
Ademais, os intérpretes enfatizaram a importância do direito à dignidade humana, que é gravemente violado com a intolerância motivada por impulsos racistas, especialmente dirigida aos grupos minoritários do país. Explicaram que o Estado Brasileiro não pode somente ratificar diversos tratados internacionais sobre o assunto e não chegar a efetivar este direito na prática, que é o que se encontra em jogo no caso em tela.

Assim, interpretam o termo racismo à luz do ideal de igualdade visado pela Constituição e demais legislações internacionais, afirmando que todos os seres humanos pertencem a uma mesma espécie, não existindo uma divisão entre raças humanas. Racismo, então, seria a manifestação de qualquer pensamento que prime por essa divisão, utilizando-se de estigmas para marginalizar um determinado grupo de pessoas. É uma conduta que atenta contra os princípios nos quais se erige e se organiza a sociedade humana, baseada na respeitabilidade e dignidade do ser humano e de sua pacífica convivência no meio social. Se os judeus passam por esse tipo de segregação eles também podem ser incluídos dentro do termo raça.

É destacado, ainda, que a Assembleia Geral da Organização das Nações Unidas proclamou, na resolução $n^{\circ} 623$, que o antissemitismo e todos os atos de intolerância a ele relacionados são formas contemporâneas de racismo.

Com isso, entenderam que o réu tinha dolo de incitar a discriminação, ao veicular ideias antissemitas, que buscavam resgatar e dar credibilidade à concepção nazista acerca dos judeus, imputando-os como uma raça inferior, e por conta disso, negavam e subvertiam fatos históricos incontroversos como o Holocausto.

Os magistrados justificaram também a existência da cláusula de imprescritibilidade imposta a esse crime em específico, dizendo que ela se deve a gravidade e repulsa dessa ofensa e para que se perpetue eternamente o repúdio da sociedade nacional a essa prática. Ela foi criada como um alerta grave para as gerações atuais e futuras que não se pode mais restaurar antigas concepções ultrapassadas, inconciliáveis com os padrões éticos e 
morais definidos na Constituição Federal e no mundo contemporâneo, sob os quais se ergue e se harmoniza o Estado Democrático de Direito.

A votação infelizmente não foi unânime, havendo três votos dissidentes. Um deles foi o do Ministro Moreira Alves, relator original do processo. Este decidiu por conceder a ordem de habeas corpus, entendendo que a população judaica não estaria abarcada dentro da expressão raça, e então não poderia sofrer racismo, baseando sua opinião em algumas afirmações ditas por doutrinadores judeus, que afirmaram que o povo judeu não se vê como uma raça. $\mathrm{O}$ magistrado, ainda, realiza uma interpretação histórica, analisando algumas mensagens da época da edição da Constituição de 1988, intuindo que a intenção do constituinte, ao editar a cláusula de imprescritibilidade do racismo, era a de combater apenas a discriminação sofrida pelos negros e combater os conflitos entre brancos e pretos. Logo, esta norma deveria ser interpretada restritivamente para incluir apenas essa forma de discriminação.

$O$ voto que iniciou a divergência em relação ao voto do Relator foi o do Ministro Maurício Correa, que foi o primeiro a defender a mudança no sentido do termo racismo, a fim de incluir os judeus nele. O jurista passa a considerar o uso da concepção social do significante racismo, lastreando sua visão em opiniões de sociólogos, antropólogos, bem como de normas internacionais, que já passaram a ampliar o conceito de racismo. Assim, os judeus podem ser considerados como sujeitos passivos do crime de racismo, não porque eles são biologicamente uma raça, mas em razão da filosofia antissemita os enxergar como raça, com o escopo de diminuí-los em relação à raça ariana. Da afirmação do Ministro depreende-se o conceito social de raça, aquela que ocorre por meio de uma valoração negativa de determinados grupos sociais com características comuns. Além disso, o magistrado utilizou trechos da Bíblia para ressaltar a discriminação sofrida pelo povo judeu ao longo da História, afirmando que negar essa proteção a mais que a Constituição concede ao crime de racismo seria negar séculos de sofrimento a esse segmento populacional. 
Os outros votos vencidos foram os dos Ministros Carlos Ayres Britto e Marco Aurélio. Estes focaram mais na discussão envolvendo a liberdade de expressão, suscitada no primeiro capítulo deste trabalho. Apesar de não ter sido uma das teses defensivas do impetrante, os Ministros entenderam que o réu não abusou do seu direito à liberdade de expressão, resolvendo que sua intenção era apenas de dar a sua opinião e impulsionar debates acerca de determinados fatos históricos, como o Holocausto. $\mathrm{Na}$ opinião desses juristas não houve dolo de discriminar ou incitar a discriminação contra os judeus na conduta do réu, considerando a conduta como atípica. Entretanto, a maioria do Supremo rechaçou a tese defendida pelos Ministros, assentando que, como qualquer direito individual, a liberdade de expressão não possui caráter absoluto. Pode, então, ser afastada quando ultrapassar seus limites morais e jurídicos, como é o caso em tela, em que há manifestações que se revestem de claro conteúdo imoral, atingindo os direitos à dignidade humana e igualdade alheios. Implica, portanto, em ilicitude penal, não havendo possibilidade de o direito à liberdade de expressão prevalecer nesse caso em concreto.

Importa destacar que Ministro Carlos Ayres Britto julgou, em caráter subsidiário, que caso a conduta fosse considerada criminosa, seria imprescritível, entendendo, conforme a maioria, que o termo racismo inclui também o antissemitismo. Então, apenas dois ministros que se opuseram a essa interpretação.

Por fim, pode-se constatar que a importância desse julgamento se deve a adoção do conceito de racismo social como o conceito constitucional de racismo, passando a incluir demais minorias estigmatizadas no combate à discriminação promovida pela Constituição Federal, dando enfoque aos preceitos constitucionais da igualdade, do pluralismo e da dignidade humana e confirmando de vez o caráter não-absoluto da liberdade de expressão em face desses preceitos.

Ainda assim, mesmo com a ampliação da abrangência dos termos raça e racismo, o STF não inclui todos os grupos vulneráveis dentro do 
âmbito de aplicação da Lei Caó. Uma evidência disso foi o julgamento do inquérito n. 3590/DF pelo Supremo ${ }^{71}$. A lide versava sobre uma denúncia feita pelo MPF imputando a prática do Art. 20 da Lei n. 7.716/89 ao Deputado e Pastor Marco Feliciano, que propagou diversas manifestações de cunho homofóbico em mensagens na rede social Twitter. A $1^{\mathrm{a}}$ Turma do Tribunal entendeu que a interpretação do delito não poderia se estender aos homossexuais, dado que a referida Lei não traz a orientação sexual como uma de suas hipóteses de incidência. Interpretam, então, que não se pode haver interpretação extensiva de uma norma penal, devendo ser respeitado o princípio da legalidade. Logo, apesar de considerarem a conduta do autor extremamente reprovável, a julgaram como atípica.

O que se pode inferir das decisões desses dois casos é que existe a expressão racismo lato sensu e o racismo stricto sensu. Em sentido amplo é o racismo em sua concepção histórica-social, que inclui qualquer grupo que sofra preconceitos efetivamente históricos, estigamatizantes, inferiorizantes e desumanizantes. É o racismo que está presente no texto da Constituição. E em sentido estrito, que é a concepção biológica, utilizada pelo texto da Lei Caó, posto que ele diferencia raça de etnia, cor, procedência nacional e orientação religiosa, sendo que, pelo julgamento do caso Ellwanger, todos são uma forma de racismo.

Ademais, o julgamento do inquérito n. 3590/DF demonstra, mais uma vez, a hierarquização de opressões criada pela Lei do Racismo, que acaba estimulando o sistema segregacionista vigente na sociedade. Se compararmos com o caso Ellwanger, nota-se a diferença de tratamento das condutas. Ainda que ambas se tratem de uma manifestação discriminatória contra um grupo estigmatizado, apenas uma delas é considerada crime. A distinção, que é ignorada pelo legislador, é gravíssima, não levando em consideração o histórico de preconceito e discriminação que também assola a minoria LGBT.

\footnotetext{
${ }^{71}$ STF, Inq: 3590 DF, Rel. Min. Marco Aurélio, primeira turma, julgado em: 12.08.2014.
} 
Nesse sentido, foi impetrado o Mandado de Injunção coletivo $\mathrm{n}^{\mathbf{o}}$ 4733/DF ${ }^{72}$. O mandado compara o significado de racismo social com os significados de homo e transfobia. Ao analisar a descrição dada por diversos sociólogos e antropólogos a esses termos, ele afere que seus significados convergem em um mesmo sentido, sendo os últimos uma espécie do primeiro. Somado a isso, o mandado utiliza os argumentos proferidos pelos Ministros para incluir o antissemitismo como forma de racismo, constatando que os mesmos também se aplicam aos casos de homo e transfobia, principalmente no que toca ao compromisso estatal em coibir violações de direitos humanos, a interpretação em favor de proteção a esses mesmos direitos, e mudança de concepção de racismo, para a atual concepção político-social. Sendo assim, essas minorias também estariam incluídas no Art. 5 , XLII, CRFB/88, o que caracteriza um mandado de criminalização constitucional obrigando o Congresso Nacional a criminalizar o preconceito e a discriminação contra essa parte da população.

Assim, o mandado objetiva a declaração da mora inconstitucional do Congresso Nacional na criminalização específica da homofobia e transfobia, fixando um prazo razoável para que seja efetivada tal criminalização, mediante o argumento da proteção eficiente, com a inclusão das discriminações e discursos de ódio motivados na orientação sexual e/ou na identidade de gênero na Lei de Racismo - Lei n. ${ }^{\circ}$ 7.716/89, bem como mediante agravantes genéricas e qualificadoras específicas no Código Penal. Caso seja superado tal prazo sem tal criminalização específica, o mandado pleiteava a aplicação da interpretação conforme à Constituição, enquadrando a homo e transfobia como espécie do gênero racismo, tornando aplicável os crimes da Lei Caó em casos de homo e transfobia, ou, subsidiariamente, que se efetive atuação legislativa atípica pela Suprema Corte para gerar tal efeito concretista mediante outra normatização provisória, geral e abstrata, que ela julgar constitucionalmente adequada.

\footnotetext{
${ }^{72}$ STF, MI: 4733 DF, Rel. atual: Min. Edson Fachin, em julgamento.
} 
Inicialmente, foi designado o Ministro Ricardo Lewandoski, que julgou pelo não conhecimento do mandado. O magistrado utiliza como um de seus argumentos a interpretação dada por Guilherme Nucci acerca do termo raça, afirmando que a Lei n. 7.716/89 já criminaliza a homofobia e transfobia, logo não há omissão do Congresso Nacional. Percebe-se a falta de sentido deste argumento, tendo em vista o julgamento do Inquérito $n$. 3590/DF visto acima, que diz exatamente o contrário.

Posteriormente, o Ministro Edson Fachin substituiu Lewandoski como relator e escolheu reconsiderar a decisão monocrática anteriormente proferida, compreendendo que havia cabimento formal para o julgamento de mérito da causa. O processo atualmente ainda se encontra na fase de instrução, já havendo manifestação do Procurador-Geral da República, Rodrigo Janot, e dos únicos Amicus Curiae do processo: o Conselho Federal de Psicologia e o Grupo Dignidade pela cidadania de gays, lésbicas e transgêneros. Todos os três defenderam a procedência dos pedidos.

Também tramita a Ação Direta de Inconstitucionalidade por Omissão n. 26, que versa sobre a mesma matéria. Imperioso destacar que também já existe decisão do TRT da $2^{\mathrm{a}}$ Região que, ao analisar a homofobia e transfobia existentes dentro do âmbito trabalhista, argumenta pela equiparação das mesmas aos demais elementos normativos da Lei $n$. $7.716 / 89^{73}$.

Outro ponto importante a ser abordado é a questão da análise do dolo de praticar, incitar ou induzir a discriminação em determinadas manifestações públicas. Apesar de já ser praticamente um consenso na jurisprudência de que a liberdade de expressão não prevalece em casos de discurso de ódio, em muitas ocasiões existe uma linha tênue que separa esses dois institutos, gerando diversas controvérsias.

Em alguns casos o discurso de ódio resta evidente, como o caso da Mayara Petruso, que postou a seguinte frase na rede social Twitter:

\footnotetext{
${ }^{73}$ RO 01010-2008-078-02-00-9, 4. ${ }^{\text {a }}$ T., Rel. Wilma Nogueira de Araujo Vaz da Silva, julgamento em 13.04.2010.
} 
"nordestino não é gente. Faça um favor a SP: mate um nordestino afogado!"74. Ela foi condenada em primeira e segunda instâncias a 2 anos de reclusão em regime aberto, além do pagamento de 10 dias multa. Contudo, mesmo passados oito anos desde o fato, a decisão ainda não transitou em julgado, havendo 2 habeas corpus impetrados perante o STJ e o STF, já rejeitados.

A mesma clareza do dolo pode ser evidenciada no caso em que um bancário classificou, em uma matéria jornalística de periódico local, os judeus como:

Uma das três ervas daninhas do mundo, justamente com os ratos e as baratas, chamando os membros da religião de câncer do Oriente Médio e atribuindo aos hebreus, indistintamente, os vícios de roubar, torturar, matar, destruir, etc ${ }^{75}$.

O autor foi condenado a dois anos de reclusão e multa, porém a pena foi substituída por prestação de serviços à comunidade.

Noutro giro, em outros casos a distinção entre liberdade de expressão e racismo não se mostrou tão evidente. Um exemplo, foi o HC 134.682 julgado pelo $\mathrm{STF}^{76}$, que dizia respeito à prática de discriminação em razão da orientação religiosa. A lide versava sobre um reverendo da Igreja Católica Apostólica Romana que publicou o livro "Sim, Sim, Não, Não, Reflexões de cura e libertação", cujo propósito é criticar práticas espíritas (para o autor isso inclui o espiritismo, a umbanda e o candomblé), alegando que todas provêm do demônio e que "o espiritismo é como uma epidemia e como tal deve ser combatido: é um foco de morte". Assim, ele propõe a salvação dos praticantes dessas religiões, que seria alcançada através de uma mudança de fé, eles precisariam abandonar a fé nessas religiões tidas como maléficas, e começar a adotar os ensinamentos cristãos.

\footnotetext{
74 TRF-03, Apelaçao Criminal n. 0012786-89.2010.4.03.6181/SP. Rel. Des. Fed. Paulo Fontes, $5^{\mathrm{a}}$ Turma. Julgamento em: 13.7.2015.

${ }^{75}$ TJ RJ, Apelação Criminal n. 5.005/99. Rel. Des. Salim José Chalub. 6 a Câmara Criminal.

${ }^{76}$ STF, RO em HC. N. 134.682 Bahia. Rel. Min Edson fachin. Primeira turma. julgamento em 29.11.2016.
} 
O paciente suscitou a prescrição do crime, todavia, o STF ratificou seu entendimento acerca da concepção político-social do termo racismo, afirmando que todos os crimes da Lei 7.716/89 são imprescritíveis.

Por outro lado, a Suprema Corte, por maioria, concedeu a ordem, se manifestando a favor da liberdade de expressão religiosa. O Ministro Edson Fachin, relator desse processo, se baseando na teoria de Norberto Bobbio, estabeleceu requisitos para a caracterização de um discurso discriminatório para fins penais, que deve ultrapassar três etapas: uma de caráter cognitivo, em que o discurso atesta a desigualdade entre grupos e/ou indivíduos; outra de viés valorativo, em que se assenta a suposta relação de superioridade entre eles e, por fim; uma terceira, em que o agente, a partir das fases anteriores, supõe legítima a dominação, exploração, escravização, eliminação, supressão ou redução de direitos fundamentais do diferente que compreende inferior. Essa mesma classificação já havia sido apontada por Gilmar Mendes no caso Ellwanger.

Para o Ministro, a conduta em tela não se trata de um discurso discriminatório, posto que só ultrapassou as duas primeiras etapas, não chegando a propor uma dominação, subjugação, extermínio ou redução de direitos de uma coletividade. Ele considera esse discurso, chamado de proselitismo, como uma prática costumeira dentro do catolicismo e cristianismo. Essas religiões visam o universalismo, isto é, objetivam a conversão de todas as pessoas e, para alcançar esse objetivo, o jurista compreende que é normal a utilização de argumentos com base na hierarquização de religiões, almejando demonstrar superioridade de suas próprias crenças, ainda que acarrete "incômodas comparações religiosas".

Então, Fachin considera o proselitismo como fruto da liberdade de expressão religiosa, caracterizando a conduta do réu como atípica. Para ele, o livro propõe apenas a salvação e resgate desses fieis, e apesar de considerar essa proposta um discurso intolerante, pedante, preconceituoso e prepotente, ela não se amolda no tipo penal do racismo. 
O questionamento importante a ser feito com base nesse julgamento é a distinção a respeito da liberdade de expressão e da liberdade de expressão religiosa e os limites para o exercício de ambas. Qual a diferença entre essa conduta e a conduta do caso Ellwanger? Ambos publicaram livros atribuindo qualificações negativas acerca de um grupo de pessoas, ligados apenas por suas orientações religiosas, e incitaram o combate a esses grupos. Não obstante o livro do sacerdote utilizar a expressão salvação, não deixa de ser uma forma de combate, uma vez que não aceita as práticas de crenças diferentes das cristãs e promove sua extinção. Não raras foram as ocasiões em que a Igreja Católica se utilizou do argumento da "salvação" para oprimir minorias, como foi o caso da Inquisição.

A diferença entre um livro e outro, então, são as justificativas utilizadas para o combate, um se baseou em argumentos religiosos e o outro não. Significaria dizer que basta justificar sua intolerância com base em ensinamentos religiosos para que ela seja lícita no Direito Penal? É no mínimo estranho o argumento vitorioso no Supremo, entendendo que a intolerância está embutida dentro da liberdade de expressão religiosa, normalizando práticas discriminatórias e intolerantes dentro da seara do exercício da fé. Ainda mais controvertido foi o argumento utilizado pelo Ministro Barroso, que ressaltou a importância do instituto do hate speech e da restrição da liberdade de expressão, mas entendeu que os espíritas não são um grupo vulnerável suficiente para invocar a exceção à liberdade de expressão, sendo que na realidade brasileira, as religiões do candomblé e da umbanda são as que mais sofrem preconceito e discriminação.

$\mathrm{O}$ direito à liberdade de expressão religiosa, assim como direito à liberdade de expressão, não é absoluto e também é passível de sofrer restrições. O livro do reverendo não só desqualifica aqueles que exercem as religiões da umbanda, candomblé, e espírita, como também vai de encontro com os próprios ensinamentos cristãos, que primam pelo respeito ao próximo. 
Outro caso controvertido foi o do escritor e colunista Diego Mainardi, que emitiu comentários discriminatórios acerca do povo nordestino em um programa de TV a cabo $^{77}$. Apesar de ser um caso especificamente para discutir o conflito de competência entre a justiça estadual e a justiça federal, o STJ também analisou se o trancamento das investigações seria prematuro ou não, vindo a apurar a tipicidade das ações do réu.

Este proferiu, no programa Manhattam Connection da Globo News, que:

O Nordeste sempre foi retrógrado, sempre foi governista, sempre foi bovino, sempre foi subalterno em relação ao poder, durante a ditadura militar, depois com o reinado do PFL e agora com o PT. É uma região atrasada, pouco educada, pouco construída que tem grande dificuldade para se modernizar na linguagem. A imprensa livre só existe da metade do Brasil para baixo. Tudo o que representa a modernidade tá do outro $1 \mathrm{lado}^{78}$.

Alguns Ministros apuraram a conduta do réu à luz da descrição da discriminação étnico-racial definida pelo Art. $1^{\circ}$, parágrafo único, inciso I, da Lei 12.288/10:

Anular ou restringir o reconhecimento, gozo ou exercício, em igualdade de condições, de direitos humanos e liberdades fundamentais nos campos político, econômico, social, cultural ou em qualquer outro campo da vida pública ou privada.

Assim, para eles só haveria crime se houvesse essa intenção específica de restrição de direitos a uma coletividade. No entanto, essa não foi a tese vencedora, sendo compreendido, que a prática da discriminação contida no Art. 20 da lei 7.716/89 não se limita a esse objetivo contido na Lei 12.288/10, portando caráter mais abrangente.

Ademais, a discriminação contra nordestinos pode ser enquadrada como hipótese de preconceito e discriminação por procedência nacional.

\footnotetext{
${ }^{77}$ STJ, Conflito de competência n. 146.983. Rel. ministro Felix Fischer. julgamento em 24.5.2017.

${ }^{78}$ MANHATTAM CONNECTION. Globo News, Rio de Janeiro. Rede Globo, 26 de outubro de 2014. Programa de TV.
} 
Por isso, julgaram pelo não trancamento da ação, decidindo que haveria possibilidade de a conduta ser típica, caso a tipicidade seja verifica pelo juízo a quo. O caso ganhou demasiada repercussão nas redes sociais, causando uma revolta da população nordestina. $O$ autor chegou a se desculpar pelos termos utilizados, mas ainda não há decisão definitiva sobre o caso.

Um caso semelhante foi o do advogado e jornalista Paulo Gilberto da Silva Correa, que aduziu na coluna Bom Dia Amigos do Jornal Cassino no Rio Grande do Sul as seguintes assertivas ${ }^{79}$ :

Precisamos é corrigir, o quanto antes, o erro de todos os anos aceitar os índios aqui, com tudo pago. A primeira vez vá lá, era novidade, 'talvez fosse alguma atração turística'. Mas depois que se viu que muitos índios não têm nenhum hábito de higiene, que fazem cocô e xixi em qualquer lugar, que raramente tomam banho, que pedem esmolas nas esquinas do Cassino, era para enviar a tribo a outro local, não mais para cá, pelo menos até que a Funai pagasse a estadia e os ensinasse a se comportar na civilização;

'(...) como alguns índios não são chegados ao banho, os forasteiros acampados cheirarão fedores, verão bugigangas de camelôs vendidas como se fossem artesanato indígena, desprestigio ao lugar aprazível que é nosso (...) Chega de importar pobrezas e fedores: já temos demais.'

'(...) Já tivemos outros medos e o mais recente é o fedor dos índios no Cassino. Se desse para evitar mais esses medos, a região ficaria agradecida...'.

O Tribunal confirmou a condenação de primeira instância, asseverando que as afirmações do denunciado constituíram evidente manifestação e incitação da discriminação étnica, posto que teceu considerações notoriamente etnocêntricas, imbuídas de aversão e menosprezo aos indígenas, unicamente pelo fato de serem indígenas, valorizando apenas a cultura, os valores e costumes dos "brancos civilizados". O réu foi condenado a 2 anos de reclusão e 16 dias-multa.

Nota-se a semelhança com o caso anterior, em que o jornalista proferiu diversos termos pejorativos ao Nordeste (e por conseguinte aos

\footnotetext{
79 TRF 4, Apelação criminal n. 2003.71.01.001894/RS. Rel. Des. Fed. Paulo Afonso Brum Vaz. Região. julgamento em 5.4.2006.
} 
nordestinos), os chamando de bovino, retrógados, atrasados, subalternos, pouco educados e pouco modernizados, devendo haver o mesmo entendimento acerca de sua conduta.

Imperioso salientar também que a criação de comunidades e páginas na internet com conteúdo discriminatório, como "100\% branco", "racista não, higiênico", "adolf hitler lovers", "orgulho branco", etc., por si só já caracterizam o fito de propagar ideais discriminatórios. Esse foi o entendimento do TRF-5 ${ }^{8081}$, em que os criadores dos websites foram condenados, tendo sido compreendido que a intenção dos réus ultrapassava o mero exibicionismo, uma vez que se utilizavam da vastidão de membros das redes sociais para divulgar discursos racistas, caracterizando o dolo específico da conduta.

Por outro lado, há casos em que a liberdade de expressão prevaleceu, sendo verificadas intenções diversas da de praticar, incitar ou induzir a discriminação.

Primeiramente, há o caso da Camila Nogueira Almeida que foi denunciada pela prática de racismo contra os médicos cubanos do programa "Mais Médicos"82. Camila utilizou-se de perfil próprio em uma rede social para publicar a seguinte afirmação:

\begin{abstract}
Nojo de morar nesse país, onde as pessoas se vendem pelas misérias desse governo lixo! Pronatec, ciência sem fronteira? Pelo amor de Deus, isso sempre existiu! Bolsa família? Não foi ela também!! Porque vocês não pedem pros médicos cubanos atenderem vocês? Peçam a deus pra que não precisem deles! Ou não precisem ser atendidos no sus, onde não tem equipamento e os médicos são coagidos a atende cada dia mais sem suporte pra isso ${ }^{83}$.
\end{abstract}

O Tribunal decidiu acertadamente que o texto não se tratava de discurso de ódio, visto a circunstância em que ele foi proferido e o grau mínimo da suposta lesão. A autora estava apenas emitindo sua opinião

\footnotetext{
${ }^{80}$ Apelação criminal n. 12191/PB, Processo originário n. 0001176-87.2011.4.05.8201. Rel. des. Fed. Lázaro Guimaraes. julgamento em 19.1.16.

${ }^{81}$ Processo n. 200881000016774. Rel. DESEMBARGADOR FEDERAL MANOEL ERHARDT, Primeira Turma, julgamento 16/02/2012, PUBLICAÇÃO: DJE 24/02/2012.

${ }^{82}$ TRF-2, Recurso em Sentido Estrito 0000021-37.2015.4.02.5115 RJ, Rel. Messod Azulay Neto, $2^{\circ}$ Turma Especializada, julgamento em 14.12.2016.

${ }^{83} \mathrm{Ibid}$.
} 
pessoal acerca de uma medida do governo, sem se pautar em qualquer teoria discriminatória ou preconceito, não havendo violação de qualquer direito fundamental. Além disso, o Tribunal entendeu que, pelo fato de seu perfil ter pouco mais de 500 amigos, o grau de repercussão da manifestação era ínfimo.

Outro precedente envolveu a música "Veja os Cabelos Dela" do parlamentar Tiririca, que continha as seguintes passagens:

Veja veja veja veja veja os cabelos dela/Parece bom-bril, de ariá panela/Parece bom-bril, de ariá panela/Eu já mandei, ela se lavar/Mas ela teimo, e não quis me escutar/Essa nega fede, fede de lascar ${ }^{84}$.

O autor foi absolvido da acusação de prática de discurso de ódio, entendo o Tribunal que ele se utilizou de expressão racista, mas que não havia dolo de discriminar ou ofender um número indeterminado de pessoas. Os magistrados interpretaram que a intenção era apenas de realçar um predicado de uma pessoa de sua relação, seria uma mera referência a características da pessoa. Foi decidido que nem o compositor, nem o presidente da gravadora e nem o diretor de marketing, poderiam ser condenados. No entanto, a Sony (gravadora da música) foi condenada no âmbito cível a pagar 1,2 milhões de reais para por danos morais provocados pela letra da música ${ }^{85}$.

Outro exemplo foi uma coluna humorística nomeada de " $O$ Paciente Jamaicano", em que o autor, ao relatar uma viagem à Jamaica, escreveu a seguinte frase: “...Pô Pitta, a gente tentando limpar o preconceito no Blequitude e tu provando que quando não suja na entrada, suja na saída." ${ }^{86}$. Ela foi considera ofensiva e racista por diversas entidades envolvidas na defesa do negro. Porém, o TJ/MG reverteu a decisão monocrática de primeira instância para absolver o réu, entendendo que a

\footnotetext{
${ }^{84}$ Apelação Criminal n. 1998.050.01069, Rel. Des. Afranio Sayão, Segunda Camara Criminal, TJ RJ, julgamento em 3.11.1998.

85 Disponível em: <https://veja.abril.com.br/entretenimento/justica-condena-gravadora-porracismo-em-musica-de-tiririca/>. Acesso em: 28 fev. 2018.

${ }^{86}$ Apelação Criminal n. 1.0000.00.229590-5/00. Rel. Des. Edelberto Santiago. TJ MG. $1^{\circ}$ câmara criminal. julgamento em 28.5.2002.
} 
intenção de quem escreveu foi só a de praticar humor, não havendo qualquer dolo, direto ou eventual, em praticar, incitar ou induzir a discriminação contra a população negra.

Há também o caso de Dominique Pierre Fraga, francês naturalizado brasileiro, que endereçou cartas ao Governador de Estado de Santa Catarina e ao Presidente da República, bem como publicou artigos no Jornal Vale do Norte, militando na defesa dos colonos contra a existência da população indígena ${ }^{87}$. O autor condena o movimento indígena por ser anticristão e apela aos governantes que apurem uma possível invasão dos indígenas, apontando que estes se encontram fortemente armados e imputa a prática de alguns crimes a essa mesma população.

O Tribunal entendeu que tal discurso não continha manifestações discriminatórias nem preconceituosas e que se tratava de um discurso apaixonado e extremista, típico de uma facção da Igreja Católica. Portanto, entende pela prevalência da liberdade de expressão e julga atípica a conduta.

Um último ponto importante a ser abordado acerca da aplicabilidade da Lei n. 7.716/89 é o fato de boa parte de seus julgados versarem sobre a confusão existente entre o tipo de injúria preconceituosa e o crime de racismo em si. Muitos casos se tratam da desclassificação do crime de racismo para a injúria qualificada, quase sempre resultando em arquivamento por falta de representação da vítima. Isso demonstra a falta de conhecimento de alguns operadores do direito acerca do assunto, mesmo anos após a criação da lei, seja por delegados que indiciam pelo crime errado ou promotores que fazem o mesmo na denúncia ou juízes que alteram a tipificação do crime no processo.

Enfim, é possível concluir a partir da análise desses e outros julgados, que a tese da prevalência da liberdade de expressão já resta superada, havendo poucos intérpretes que ainda defendem esse ponto de

${ }^{87}$ TRF 4, Habeas Corpus n. 2001.04.01.0855030-6/SC. Rel. Des. Fed. Vladimir Freitas. Região. julgamento em 19.2.2002. 
vista (com exceção da liberdade de expressão religiosa). Porém, para que seja caracterizada a discriminação preconceituosa é necessário que o indivíduo aja com vontade livre e consciente de diminuir, humilhar, segregar e de excluir o outro, como se não fosse merecedor de igual respeito enquanto pessoa. Desse modo, não haverá crime se houver outro ânimo, por exemplo, o de brincar (animus jocandi) ou de fazer uma descrição ou crítica artística (animus criticandi). Será da Acusação o dever de provar o dolo do agente, devendo haver a absolvição em caso de dúvidas acerca de sua intenção, conforme o Art. 386, VII do CPP.

Já em relação a discriminação praticada contra pessoas idosas, há um número significativo maior de condenações. Isto se deve ao entendimento dos Tribunais de que o Art. 96, $\S 1^{\circ}$ do Estatuto do Idoso não necessita de um dolo específico baseado no preconceito, como os crimes da Lei $7.716 / 89^{88}$. Destarte, qualquer humilhação, menosprezo ou prática de discriminação contra pessoa idosa, seja por ela ser idosa ou não, será caracterizado o delito. No entanto, também existe entendimento jurisprudencial no sentido de que a ofensa precisa ser baseada na idade da vítima $^{89}$. Além disso, esse crime geralmente anda em conjunto com demais delitos contra o idoso (como a violência física) o que colabora para o resultado condenatório do processo.

Em relação as demais leis antidiscriminação, destaca-se que existem poucos julgados sobre elas. A Lei n. 7.437/85, que alterou a Lei Afonso Arinos, e que estaria em vigor em virtude do preconceito de gênero e estado civil, é completamente desconhecida pela jurisprudência, não havendo registros de qualquer condenação por uma de suas contravenções. O mesmo ocorre com a Lei 12.984/14 que criminaliza a discriminação dos portadores de HIV e com o Art. 88, $\S 2^{\circ}$ da Lei n. 13.146/2015. A única ocorrência constatada de ofensas dirigidas às pessoas com deficiência foi

${ }^{88}$ TJ-DF, APJ n. 20130710294598. Rel. Fernando Antonio Tavernard Lima. julgamento em 17.5.2016.

${ }^{89}$ TJ-SE APR n. 2007311900/SE. Rel. Vaga de desembargador(Des. Pascoal), julgado pela juíza convocada Elvira Maria de Almeida Silva. julgamento em 7.1.2008. 
uma piada realizada por um Promotor de Justiça na internet acerca da falta de um dos dedos do ex-Presidente Luís Inácio Lula da Silva, que foi imediatamente arquivada ${ }^{90}$.

A própria Lei n. 7.716/89, ainda que mais aplicada que a maioria, também encontra dificuldades em sua divulgação e aplicabilidade. Para o Presidente da Comissão do Negro e de assuntos Antidiscriminatórios da Ordem dos Advogados do Brasil, Marcos Antônio Zito Alvarenga, a pouca quantidade de casos enquadrados por essa lei se deve ao fato de que muitos policiais, promotores e juízes entenderem que a pena para os crimes de racismo é muito alta, criando barreiras para sua aplicação. Já para o exMinistro da Igualdade Racial, Edson Santos, o problema se encontra na falta de qualificação dos agentes públicos para tratar do assunto, que muitas vezes tipificam a conduta como injúria, que é uma ação penal pública condicionada à representação, logo há um prazo de 6 meses para a vítima representar, que frequentemente não é observado pela falta de informação dada à vítima. Somado a isso, há a opinião da Presidente do Conselho Estadual de Participação e Desenvolvimento da Comunidade Negra de São Paulo, Elisa Lucas Rodrigues, que avalia que a Lei não é utilizada por sua falta de divulgação, defendendo também a necessidade de uma reformulação da Lei Caó ${ }^{91}$.

Ainda, a grande quantidade de leis diferentes sobre o discurso de ódio acaba dificultando seu grau de eficácia. A divulgação de uma lei específica para o conhecimento dos cidadãos já é uma difícil conquista, ainda mais diversas leis, que versam sobre conteúdo semelhante e que possuem uma matéria sensível, visto que existe certa resistência a entender que essa prática é crime em razão da preferência ao direito de liberdade de expressão. Christiano Jorge Santos já aponta que existe um demasiado

\footnotetext{
${ }^{90}$ TJ-SP, Representação Criminal n. 2121835-28.2017.8.26.0000. Rel. Sales Rossi. julgamento em 9.8.17.

${ }^{91}$ Disponível em: <http://g1.globo.com/Noticias/Brasil/0,,MUL1276437-5598,00-.html〉. Acesso em: 02 mar. 2018.
} 
número de leis sobre o assunto, que são pouquíssimos aplicadas, demandando por uma sistematização maior ou uma unificação legislativa ${ }^{92}$.

A criação de todas as normas de combate ao preconceito e discriminação foi uma grande conquista da sociedade brasileira. Mas de nada adianta elas existirem no papel se elas de fato não são devidamente conhecidas e aplicadas. A pouca eficácia dessas normas é um dos grandes fatores que propulsionam e estimulam a impunidade das práticas preconceituosas no Brasil.

\subsection{Análise Empírica dos Crimes de Ódio no Brasil}

Já analisamos que o crime de discurso de ódio, bem como os demais delitos de preconceito e discriminação estudados no capítulo anterior, foi criado porque ele é, por si só, uma ofensa a bens jurídicos alheios. No entanto, eles visam não só proteger os bens jurídicos em jogo, mas como também impedir a prática de crimes mais graves, como o homicídio, genocídio, a tortura, a lesão corporal, o dano, etc., baseados no preconceito e na discriminação.

Os crimes quando praticados com essa motivação específica recebem a denominação pelo direito norte americano de "hate crimes". Nessa legislação, há uma qualificadora de ordem subjetiva para todo e qualquer crime que possui essa intenção especial, que torna a conduta perpetrada mais vil do que os crimes dos tipos simples. Tendo em vista isso, torna-se imperioso destacar os índices da prática de hate crimes no Brasil, a fim de demonstrar a gravidade da realidade discriminatória no território nacional.

Nessa seara, o Instituto de Pesquisa Econômica Aplicada (Ipea), em conjunto com Fórum Brasileiro de Segurança Pública, publicou o Atlas de Violência 2017 com o escopo de apurar dados e estatísticas acerca da incidentes violentos, crimes e características do sistema de segurança

\footnotetext{
${ }^{92}$ SANTOS, 2010, p. 78.
} 
público brasileiro ${ }^{93}$. Entre os dados investigados, foi analisado o índice de homicídios praticados contra negros. Segundo a pesquisa, de cada 100 pessoas que sofrem homicídio no Brasil, 71 são negras. Jovens e negros do sexo masculino continuam sendo assassinados todos os anos como se vivessem em situação de guerra. Os dados da pesquisa mostraram que a tragédia que aflige a população negra não se restringe às causas socioeconômicas. Foi estimado que o cidadão negro possui chances $23,5 \%$ maiores de sofrer assassinato em relação a cidadãos de outras raças/cores, já descontado o efeito da idade, sexo, escolaridade, estado civil e bairro de residência. Do ponto de vista de quem sofre a violência letal, a cidade do Rio de Janeiro é partida não apenas na dimensão econômica entre pobres e ricos, ou na dimensão geográfica, mas também pela cor da pele. Ao calcular a probabilidade de cada cidadão sofrer homicídio, os autores concluíram que os negros respondem por 78,9\% dos indivíduos pertencentes ao grupo dos $10 \%$ com mais chances de serem vítimas fatais.

Ao se analisar a evolução das taxas de homicídios considerando se o indivíduo era negro ou não, entre 2005 e 2015, foi verificado dois cenários completamente distintos. Enquanto, neste período, houve um crescimento de $18,2 \%$ na taxa de homicídio de negros, a mortalidade de indivíduos não negros diminuiu $12,2 \%$. O que confirmou que:

Não apenas temos um triste legado histórico de discriminação pela cor da pele do indivíduo, mas, do ponto de vista da violência letal, temos uma ferida aberta que veio se agravando nos últimos anos ${ }^{94}$.

Além disso, o relatório também aponta os dados em relação à violência praticada contra a mulher. Em 2015, 4.621 mulheres foram assassinadas no Brasil, o que corresponde a uma taxa de 4,5 mortes para cada 100 mil mulheres. Com base nesses dados do SIM não é possível, contudo, identificar que parcela corresponde às vítimas de feminicídios,

\footnotetext{
${ }^{93}$ CERQUEIRA, Daniel et al.. Atlas de Violência 2017. Ipea e FBSP. Disponível em: <http://www.ipea.gov.br/atlasviolencia/download/2/2017>. Acesso em: 08 abr. 2018. ${ }^{94}$ Ibid.
} 
uma vez que a base de dados não fornece essa informação. Ainda que a taxa de homicídio de mulheres tenha crescido 7,3\% entre 2005 e 2015, quando analisamos os anos mais recentes, foi verificado uma melhora gradual, tendo este indicador diminuído 1,5\%, entre 2010 e 2015, e sofrido uma queda de 5,3\% apenas no último ano da série. Porém, esses dados são distintos a depender da Unidade Federativa apurada. Por exemplo, enquanto São Paulo obteve uma diminuição de 34,1\% entre 2005 e 2015, o Maranhão conseguiu aumentar a sua taxa em 124,4\%.

Outra divergência importante a ser destacada é a diferença entre homicídio de mulheres não negras e mulheres negras. Em relação as primeiras, nesse mesmo lapso temporal estudado houve uma redução de 7,4\% na mortalidade, atingindo 3,1 mortes a cada 100 mil mulheres não brancas, ou seja, abaixo da média nacional. Noutro giro, em relação às mulheres negras ocorreu o oposto, houve o aumento de $22 \%$ no mesmo período, correspondendo a taxa de 5,2 mortes a cada 100 mil mulheres negras, estando acima da média nacional.

Os dados indicam ainda que, além da taxa de mortalidade de mulheres negras ter aumentado, cresceu também a proporção de mulheres negras entre o total de mulheres vítimas de mortes por agressão, passando de 54,8\% em 2005 para 65,3\% em 2015. Trocando em miúdos, 65,3\% das mulheres assassinadas no Brasil no último ano eram negras, na evidência de que a combinação entre desigualdade de gênero e racismo é extremamente perversa e configura variável fundamental para compreendermos a violência letal contra a mulher no país.

Segundo a pesquisa:

Os dados apresentados revelam um quadro grave, e indicam também que muitas dessas mortes poderiam ter sido evitadas. Em inúmeros casos, até chegar a ser vítima de uma violência fatal, essa mulher é vítima de uma série de outras violências de gênero, como bem especifica a Lei Maria da Penha (Lei 11.340/06). A violência psicológica, patrimonial, física ou sexual, em um 
movimento de agravamento crescente, muitas vezes, antecede o desfecho fatal ${ }^{95}$.

O relatório ainda remete a uma pesquisa efetuada em 2016, denominada "Visível e Invisível: a vitimização de mulheres no Brasil", encomendada ao Datafolha pelo Fórum Brasileiro de Segurança Pública, com representatividade nacional, em que foi aferido que $29 \%$ das mulheres brasileiras relataram ter sofrido algum tipo de violência segundo a pesquisa, sendo que apenas $11 \%$ dessas mulheres procuraram uma delegacia da mulher. A pesquisa também apontou que em $43 \%$ dos casos a agressão mais grave foi no domicílio.

Acerca dos idosos, em razão do avanço da medicina e da tecnologia, estes atualmente representam uma parcela significativamente numerosa da população brasileira, girando em torno de 29.566 milhões de pessoas, cerca de $14,4 \%$ de toda a população, com tendência a aumentar, segundo dados do Pnad Contínua (dados referentes ao ano de 2016) ${ }^{96}$.

O Ministério de Direitos Humanos produziu um manual de enfrentamento à violência contra pessoa idosa, em que foram apuradas diferentes estatísticas em relação a abusos cometidos contra esse grupo minoritário ${ }^{97}$. Em 2011, morreram 24.669 pessoas idosas por acidentes e violência no país, significando 68 óbitos por dia. E 169.673 deram entrada em hospital por quedas, traumas de trânsito, envenenamentos, agressões, sufocações e tentativas de suicídios. Dentro do índice de óbito, 8,4\% são de agressões, sendo $6 \%$ tentativas de homicídio. As causas mais comuns são acidentes de transporte e quedas, que juntas correspondem a quase $70 \%$ (cerca de 35\% cada) do índice de morte por acidente ou violência em 2011. Já os suicídios correspondem a $8 \%$ dos óbitos.

\footnotetext{
95 Ibid.

96 Disponível em: <https://oglobo.globo.com/economia/envelhecimento-da-populacao-aceleracresce-16-em-4-anos-no-pais-22108208>. Acesso em: 09 abr. 2018.

97 BRASIL. Secretaria de Direitos Humanos da Presidência da República. MINAYO, Maria Cecília de Souza. Brasil: manual de enfrentamento à violência contra a pessoa idosa. É possível prevenir. É necessário superar. Brasília/DF, 2014. Disponível em: <file://C:/Users/lucas/Downloads/Violencia\%20contra\%20a\%20Pessoa\%20Idosa_miolo_para\%2 0web-eleitoral.pdf>. Acesso em: 09 abr. 2018.
} 
Outrossim, o relatório aponta que desde de novembro de 2010 foi implantado o "Módulo Idoso do Disque Direitos Humanos" (o "Disque 100"), que constatou que $68,7 \%$ das comunicações realizadas são de negligência, 59,3\% são de abusos psicológicos, 40,1\% são de abusos financeiros, econômicos e violência patrimonial e 34\% são de maus-tratos. A soma dos percentuais apurados não resulta em 100, ressaltando que os abusos sofridos se sobrepõem. Todavia, enquanto no nível nacional as negligências ocupam o primeiro lugar, estudos locais demonstram dados distintos. O Manual analisa uma pesquisa feita em uma delegacia civil específica para o público idoso no Rio de Janeiro, em que foi revelado que os motivos mais frequentes das comunicações de crimes são de maus-tratos $(48,5 \%)$, constrangimento ilegal $(11,1 \%)$, apropriação indébita $(10 \%)$ e ameaças $(9,4 \%)$, havendo sido um total de 898 registros por ano.

Ainda, a pesquisa mostra que a maior parte dos abusos contra idosos são cometidos no seio familiar. Em torno de dois terços dos crimes são praticados por filhos, parentes e cônjuges, o que torna evidente a ainda maior vulnerabilidade desse grupo.

Em relação aos crimes de ódio praticados contra a população LGBT, o Relatório de Violência Homofóbica no Brasil: ano de 2013, aponta um grave quadro de violência homofóbica no Brasil. Foram reportadas 9,31 violações de direitos humanos de caráter homofóbico do total de denúncias diárias. A cada dia 5,22 pessoas foram vítimas de violência homofóbica do total de casos reportados no país ${ }^{98}$.

Somado a isso, o Grupo Gay da Bahia (GGB), no relatório de assassinatos de LGBT no Brasil ${ }^{99}$, apurou que 343 LGBT foram assassinados no nosso país em 2016, se tornando o maior registro de assassinatos em 37 anos em que o Grupo levanta dados sobre o tema.

\footnotetext{
${ }^{98}$ BRASIL. Secretaria Especial de Direitos Humanos do Ministério das Mulheres, da Igualdade Racial e dos Direitos Humanos. Relatório de Violência Homofóbica no Brasil: ano 2013. Brasília, 2016. Disponível em: <http://www.sdh.gov.br/assuntos/lgbt/dadosestatisticos/Relatorio2013.pdf>. Acesso em: 10 mai. 2018.

99 MOTT, Luiz; MICHELS, Eduardo Paulinho. Relatório 2016 Assassinatos de LGBT no Brasil. Disponível em: Disponível em: <http://bancariospa.org.br/wp3/wpcontent/uploads/2017/01/relatc3b3rio-20162.pdf>. Acesso em: 09 abr. 2018.
} 
Somado a isso, foi apurado que a cada 25 horas um LGBT é assassinado em razão da homofobia e transfobia, tornando o Brasil o campeão em homicídios contra as minorias sexuais. Há mais mortes de LGBTs aqui do que nos 13 países do Oriente Médio e África, onde há pena de morte para quem pertence a esse grupo vulnerável.

Dos 343 assassinatos, 173 eram gays (50\%), 144 (42\%) trans (travestis e transexuais), 10 lésbicas (3\%), 4 bissexuais (1\%), incluindo 12 heterossexuais, como os amantes de transexuais ("T-lovers"), além de parentes ou conhecidos de LGBT que foram assassinados por algum envolvimento com a vítima ou por serem confundidos com gays.

Proporcionalmente, as travestis e transexuais são as mais vitimizadas: o risco de uma "trans" ser assassinada é 14 vezes maior que um gay, e se compararmos com os Estados Unidos, as 144 travestis brasileiras assassinadas em 2016 face às 21 trans americanas, as brasileiras têm 9 vezes mais chance de morte violenta do que as trans norteamericanas. Segundo agências internacionais, mais da metade dos homicídios de transexuais do mundo ocorrem no Brasil.

Importa destacar também que apenas em 17\% desses homicídios o criminoso foi identificado (60 de 343), e menos de 10\% das ocorrências redundou em abertura de processo e punição dos assassinos.

Não se pode olvidar que os dados coletados nessa pesquisa são provenientes de notícias publicadas na mídia, na internet, e de informações pessoais, uma vez que não há estatísticas governamentais sobre crimes de ódio contra LGBTs, o que leva a crer que na realidade há uma subnotificação dos números aqui apresentados.

Em relação as pessoas com deficiência, constata-se a ausência de dados sobre a violência praticada contra este grupo. As poucas informações que se tem foram obtidas de dados dos canais do "Disque 100", canal para receber denúncia de qualquer cidadão sobre violação de direitos humanos, mantido pela Secretaria Nacional de Direitos Humanos da Presidência da República do Brasil, e também do "Disque-Denúncia-181", ligado à 
Secretaria de Segurança Pública de São Paulo. Ainda assim, foram observados 1209 denúncias entre fevereiro de 2011 e junho de 2013 que comunicavam a prática de alguma forma de violência contra uma pessoa com deficiência ${ }^{100}$. Ademais, somente na cidade de Campinas, foram registrados 1.441 casos de violência contra pessoas com deficiência em 2015, havendo um acréscimo de $34 \%$ em relação ao ano anterior ${ }^{101}$.

Cabe ressaltar que todos os dados aqui apresentados não correspondem ao total de violência que de fato é praticada contra os grupos vulneráveis no Brasil, tendo em vista a enorme subnotificação desses crimes. Uma parcela da população é desinformada em relação aos seus direitos, ou, em outros casos, os delitos são acometidos por familiares, o que sujeita a vítima a diversos obstáculos para procurar ajuda externa e a devida responsabilidade dos infratores, seja por minimizarem a gravidade das infrações, seja por se mostrarem leais aos seus agressores, seja por medo ou falta de recursos para subsistirem por si próprios.

A coleta de dados deve ser estimulada, a fim de que se possa realizar estudos empíricos mais precisos e com isso poder elaborar políticas públicas de segurança mais específicas para esses grupos, que sofrem uma violência e abusos de forma diferenciada do resto da população. A criação de delegacias especializadas e de disques-denúncias específicos são formas de melhorar esse sistema de coleta de dados. Além disso, a criação de tipos específicos, seja na forma de uma qualificadora ou de uma causa de aumento de pena, colabora para o combate a essas formas especiais de violência.

Temos como um exemplo disso a Lei n. 13.104/15 que criou o feminicídio como qualificadora do crime de homicídio, Art. 121, VI, CP. Muitos doutrinadores criticaram essa alteração, sob a alegação de que seria redundante, haja vista que essa qualificadora já estaria incluída no motivo

\footnotetext{
100 Visto em: Disponível em:

<http://violenciaedeficiencia.sedpcd.sp.gov.br/paginas/numeros.php>. Acesso em: 10 abr. 2018.

101 Visto em: Disponível em: <http://g1.globo.com/sp/campinas-regiao/noticia/2016/03/casos-deviolencia-contra-deficientes-crescem-34-em-campinas-sp.html>. Acesso em: 10 abr. 2018.
} 
torpe do inciso I. Contudo, a criação de uma qualificadora para essa forma específica de violência pode ajudar a contabilizar os números de homicídios cometidos pelo motivo específico da vítima ser do gênero feminino, além de afastar qualquer interpretação duvidosa se isso seria ou não um motivo torpe capaz de ensejar a qualificadora do inciso I, que poderia ocorrer em um caso concreto.

Também há uma causa de aumento quando a vítima é pessoa idosa, vide o $\S 4^{\text {o }}$ do mesmo delito. O mesmo ocorre em diversos delitos, como os de genocídio, tortura, lesão corporal, entre outros em que há disposições específicas acerca de violências e abusos cometidos contra grupos vulneráveis. Dessa forma, essa lógica deveria ser ampliada para que abarque o maior número de grupos minoritários possíveis e com isso diminuir suas vulnerabilidades. Não é simplesmente para aumentar a pena do delito, posto que isso, isoladamente, de nada ajuda, e sim para tornar visível essa forma especial de violência, e assim termos acesso a informações mais precisas, como os locais, autores, circunstâncias, situações, em que esses delitos se mostram mais presentes.

De qualquer forma, os dados são de relevante valor social e devem ser valorizados, especialmente porque demonstram a grave violência social, institucional e estrutural que é visível e difusa na nossa realidade. Eles são mais uma justificativa para que o Estado proporcione todos os mecanismos necessários para o combate do discurso de ódio, que é uma das formas de manifestação dessa ideologia odiosa e que pode incentivar a prática desses crimes mais graves. 


\section{CONCLUSÃO}

A isonomia é a pedra de toque do regime democrático. Ela, em conjunto com o respeito à dignidade humana, vai dar a base em que vai ser construída a República Federativa do Brasil. É por conta disso que a Constituição Federal de 1988 prima pela promoção da igualdade de todos, sem distinção, e, consequentemente, pelo repúdio a todas as formas de manifestação de preconceito e discriminação.

Assim, após a vasta análise dos tópicos apresentados nesta monografia, conclui-se que a resposta ao paradoxo da tolerância formulado por Karl Popper será no sentido de que a intolerância deve ser sim combatida com os mais fortes instrumentos estatais disponíveis, sob pena de se extinguir a própria tolerância. Sem embargo, não se pode, ao mesmo tempo, permitir que o Estado admita a censura prévia ou que impute responsabilidade sobre qualquer manifestação de pensamento que tenha conteúdo minimamente ofensivo, sob pena de se criar um regime do politicamente correto e extinguir o direito à liberdade de expressão. Então, o caminho a ser seguido é o caminho do meio, um ponto de equilíbrio entre os dois extremos.

Dessa forma, a Constituição veda o discurso de ódio, aquele em que possui fundamentação em preceitos diametralmente opostos ao da isonomia. Ele se consiste em uma manifestação de pensamento, cujo o único propósito é de humilhar e diminuir grupos de indivíduos, encontrando seus alvos principais nas minorias estigmatizadas da sociedade. Justificado por uma pretensa liberdade de expressão, ele nada mais é do que o uso abusivo deste direito para silenciar e retirar do espaço democrático cidadãos, em virtude de deterem certas características acidentais ou fortuitas.

A mácula que carrega a discriminação preconceituosa pode ser vista durante o processo histórico da formação da nossa sociedade. É em razão da gravidade das consequências carregadas pelo preconceito e da 
perpetuidade dessas ações ao longo de séculos no nosso território, que a Constituição escolheu não só proibir as manifestações de ódio, como também as tornar crime. Não satisfeita, a Norma Maior impôs que essa conduta seria sujeita à pena de reclusão, sendo inafiançável e imprescritível, compondo o rol ínfimo de crimes imprescritíveis, junto com a ação de grupos armados contra a ordem constitucional e contra o Estado Democrático de Direito.

Ainda que a Constituição não tenha feito ressalvas no combate à discriminação e na criminalização do racismo e que a Suprema Corte já tenha entendido que nenhum grupo vulnerável pode ser deixado à margem desse combate, essa ótica não se encontra respaldada na legislação ordinária. Ironicamente, as leis antidiscriminação possuem em seu âmago o viés discriminatório. As normas que criminalizam as manifestações de preconceito e discriminação possuem tratamento distinto a respeito de quem é a vítima. Destarte, o Estado dispensa diferentes respostas a depender do grupo vulnerável atingido, variando o tipo de infração penal, a gravidade do preceito secundário e até mesmo o ramo do Direito a ser aplicado, tudo isso para uma mesma conduta e sem nenhuma justificativa jurídica plausível para embasar essas escolhas.

Somado a isso, muitas dessas leis são completamente desconhecidas dos operadores do direito, não chegando a ser devidamente aplicadas, e outras também possuem seu grau de eficácia limitado, possuindo termos confusos e ambíguos, criando divergências e mais obstáculos a sua aplicação.

Verifica-se, então, uma necessidade de reformulação legislativa nessa área, para ampliar e uniformizar seu âmbito de aplicação. O que se pretende é alterar a Lei n. 7.716/89 para que inclua as normas antidiscriminatórias que se encontram nas legislações esparsas, bem como adicione os grupos vulneráveis que se encontram sem proteção penal atualmente, sem olvidar as especificidades discriminatórias da realidade de cada um dos grupos minoritários. A uniformização ou sistematização dessa 
mesma conduta facilitará o seu estudo e análise para os operadores do direito, para assim evitar confusões e aplicações incorretas do assunto. E principalmente, irá colaborar com uma melhor divulgação para o conhecimento e informação dos cidadãos, que frequentemente não conhecem seus direitos.

É importante frisar que o almejado por este trabalho não é o incremento da quantidade ou severidade dos tipos penais. Os crimes de discriminação já existem e já se encontram em vigor. O que se necessita é estender sua proteção para grupos que se encontram desprotegidos e uniformizar a legislação sobre o tema para melhorar sua eficácia e assim concretizar o ideal de isonomia promovido pela Constituição da República.

Ainda, não obstante a existência de diversas críticas pertinentes sobre o sistema carcerário brasileiro e as consequências da pena privativa de liberdade dentro da nossa realidade social, estas não podem servir de óbice para a aplicação da lei penal. Essas ações criminosas não podem ser livres de consequência, sendo dever do Estado fornecer uma resposta adequada e eficaz contra aqueles que atentem contra os direitos da pluralidade, da isonomia e da liberdade de se exprimir como você é. Não se pode exigir das vítimas que se mantenham inertes em uma situação de grave violação de seus direitos fundamentais, sem poder recorrer ao Poder Público para garantir a devida proteção dos mesmos e a responsabilização dos autores do ato ilícito.

Torna-se imperioso ressaltar, também, que a criminalização de condutas e o cárcere não são as únicas nem as melhores respostas para solucionar esse problema. Ainda que o Estado avance nesse âmbito de proteção, subsistem barreiras estruturais que dificultam que minorias tenham acesso aos direitos fundamentais. Por isso, é essencial a criação de movimentos sociais e programas de governo voltados para a implementação de direitos políticos, civis, econômicos e sociais para as minorias estigmatizadas, a fim de minimizar as desigualdades estruturais da sociedade. Dentre elas, destaca-se: a criação de indicadores que possam 
mensurar e fiscalizar a implementação progressiva desses direitos; a realização de campanhas e ações educativas para a desconstrução de estereótipos ligados aos grupos discriminados; a melhoria dos mecanismos de atendimento às minorias que se encontrem em situação de violação de seus direitos humanos; a elaboração de pesquisas e relatórios para apurar dados estatísticos sobre a violência sofrida por esse grupos, a fim de dar maior visibilidade ao problema e permitir a formulação de respostas mais precisas para solucioná-lo.

É somente com a educação de qualidade, conjugada com a aplicação de políticas públicas efetivas, que poderá ser alcançada a desconstrução do pensamento preconceituoso enraizado na mente da população. Ressalta-se, no entanto, que nenhuma dessas medidas é incompatível com a criminalização do discurso de ódio. Pelo contrário, a atuação em conjunto de todos esses mecanismos de combate à intolerância garante com maior segurança o respeito e proteção imprescindíveis aos direitos dos grupos vulneráveis. É fundamental a difusão de uma cultura que respeite as diferenças e que valorize a tolerância, a fim de conquistar o verdadeiro fim do preconceito e da discriminação. 


\section{REFERÊNCIAS BIBLIOGRÁFICAS}

BOBBIO, Norberto. Elogio a serenidade e outros escritos morais. NOGUEIRA, Marco Aurélio (Trad.). 2 ${ }^{\mathrm{a}}$ ed. São Paulo: UNESP, 2011.

BRASIL. Diário do Congresso Nacional. 24 ago. 1950.

BRASIL. Secretaria de Direitos Humanos da Presidência da República. MINAYO, Maria Cecília de Souza. Brasil: manual de enfrentamento à violência contra a pessoa idosa. É possível prevenir. É necessário superar. Brasília/DF, 2014. Disponível em:

<file:///C:/Users/lucas/Downloads/Violencia\%20contra\%20a\%20Pessoa\%2 0Idosa_miolo_para\%20web-eleitoral.pdf>. Acesso em: 09 abr. 2018.

BRASIL. Secretaria Especial de Direitos Humanos do Ministério das Mulheres, da Igualdade Racial e dos Direitos Humanos. Relatório de Violência Homofóbica no Brasil: ano 2013. Brasília, 2016. Disponível em: <http://www.sdh.gov.br/assuntos/lgbt/dadosestatisticos/Relatorio2013.pdf>. Acesso em: 10 mai. 2018.

BULOS, Uadi Lammêgo. Constituição Federal anotada. $10^{\mathrm{a}}$ ed. São Paulo: Saraiva, 2012.

CARCARÁ, Thiago Anastácio. Discurso de ódio no Brasil. Rio de Janeiro: Lumen Juris, 2014.

CERQUEIRA, Daniel et al.. Atlas de Violência 2017. Ipea e FBSP. Disponível em:

<http://www.ipea.gov.br/atlasviolencia/download/2/2017>. Acesso em: 08 abr. 2018.

GRECO. Rogério. Curso de Direito Penal Parte Geral. v. 1. Niterói: Editora Impetus, 2013.

MANHATTAM CONNECTION. Globo News, Rio de Janeiro. Rede Globo, 26 de outubro de 2014. Programa de TV.

MARTÍNEZ-ECHAZÁBAL. O Culturalismo dos anos 30 no Brasil e na América Latina. Rio de Janeiro: FIOCRUZ/CCB, 1996.

MENDES, Gilmar Ferreira; BRANCO, Paulo Gustavo Gonet. Curso de Direito Constitucional. 12 $2^{\mathrm{a}}$ ed. Re. e atual. São Paulo: Saraiva, 2017. 
MEYER-PFLUG, Samantha Ribeiro. Liberdade de Expressão e discurso de ódio. São Paulo: Revista dos Tribunais, 2009.

MIRABETE, Julio Fabbrini; FABBRINI, Renato N. Manual de direito penal: parte geral. v. 1. 24 ${ }^{\mathrm{a}}$ ed. São Paulo: atlas, 2001.

MORAES, Alexandre de. Direito Constitucional. $33^{\mathrm{a}}$ ed. rev. e atual. São Paulo: Atlas, 2016.

MOTT, Luiz; MICHELS, Eduardo Paulinho. Relatório 2016 Assassinatos de LGBT no Brasil. Disponível em: Disponível em:

$<$ http://bancariospa.org.br/wp3/wp-content/uploads/2017/01/relatc3b3rio20162.pdf>. Acesso em: 09 abr. 2018.

NUCCI, Guilherme de Souza. Leis Penais e Processuais Comentadas. $4^{\mathrm{a}}$ ed. São Paulo: Revista dos Tribunais, 2009.

OMMATI. José Emílio Medauar. Liberdade de Expressão e Discurso de Ódio na Constituição de 1988. Rio de Janeiro: Lumen Juris, 2016.

OSÓRIO, Fábio Medina e SCHAFER, Jairo Gilberto. Dos crimes de discriminação e preconceito: anotações à Lei 8.081, de 21-9-1990. Revista do Tribunais, v. 714.

PETRUCCELLI, José Luis. A cor denominada: um estudo do Suplemento da Pesquisa Mensal de Emprego de julho de 1998. Rio de Janeiro: IBGE, 2000.

PINTO FERREIRA, Luiz. Comentários à constituição brasileira. v. 7. São Paulo: Saraiva, 1995.

Popper, Karl. The Open Society and it's Enemies. v. 1. Londom: Butler \& Tanner Ltd., 1945. p. 226. Tradução livre.

SANTOS. Christiano Jorge. Crimes de Preconceito e de Discriminação. São Paulo: Editora Saraiva, 2010.

SARMENTO, Daniel. A Liberdade de Expressão e Problema do "Hate Speech". p. 47. Disponível em: <http://www.dsarmento.adv.br/content/3publicacoes/19-a-liberdade-de-expressao-e-o-problema-do-hate-speech/aliberdade-de-expressao-e-o-problema-do-hate-speech-danielsarmento.pdf>. Acesso em: 22 jan. 2018. 
Livres e Iguais: Estudos de Direito Constitucional. $1^{\mathrm{a}}$ ed. Rio de Janeiro: Editora Lumen Juris, 2010.

SILVEIRA, Fabiano Augusto Martins. Da Criminalização do Racismo. Aspectos Jurídicos e Sociocriminológicos. Belo Horizonte: Editora Del Rey, 2007.

TEODORO, Maria de Lourdes. Elementos básicos das políticas de combate ao racismo brasileiro. In: MUANAGA, Kabengle (Org.). Estratégias e políticas de combate à discriminação racial. São Paulo: EDUSP, 1996.

WILSON, Edward O. On Human Nature. Massachusetts: Harvard University Press - Cambridge, 1998.

\section{JURISPRUDÊNCIA}

Apelação Criminal n. 1.0000.00.229590-5/00. Rel. Des. Edelberto Santiago. TJ MG. $1^{\text {o }}$ câmara criminal. julgamento em 28.5.2002.

Apelação criminal n. 12191/PB, Processo originário n. 000117687.2011.4.05.8201. Rel. des. Fed. Lázaro Guimaraes. julgamento em 19.1.16.

Apelação Criminal n. 1998.050.01069, Rel. Des. Afranio Sayão, Segunda Camara Criminal, TJ RJ, julgamento em 3.11.1998.

Processo n. 200881000016774. Rel. DESEMBARGADOR FEDERAL MANOEL ERHARDT, Primeira Turma, julgamento 16/02/2012, PUBLICAÇÃO: DJE 24/02/2012.

RO 01010-2008-078-02-00-9, 4. ${ }^{\text {a }}$ T., Rel. Wilma Nogueira de Araujo Vaz da Silva, julgamento em 13.04.2010.

STF, Habeas Corpus n. 82.424/RS, Rel. Originário Min. Moreira Alves, Pleno, Supremo Tribunal Federal, 19 set. 2003. 
STF, Inq: 3590 DF, Rel.: Min. Marco Aurélio, primeira turma, julgado em: 12.08.2014.

STF, MI: 4733 DF, Rel. atual: Min. Edson Fachin, em julgamento.

STF, MI: 4733 DF, Rel.: atual: Min. Edson Fachin, em julgamento.

STF, RO em HC. N. 134.682 Bahia. Rel. Min Edson fachin. Primeira turma. julgamento em 29.11.2016.

STJ, Conflito de competência n. 146.983. Rel. ministro Felix Fischer. julgamento em 24.5.2017.

TJ RJ, Apelação Criminal n. 5.005/99. Rel. Des. Salim José Chalub. $6^{\mathbf{a}}$ Câmara Criminal.

TJ-DF, APJ n. 20130710294598. Rel. Fernando Antonio Tavernard Lima. julgamento em 17.5.2016.

TJ-SE APR n. 2007311900/SE. Rel. Vaga de desembargador(Des. Pascoal), julgado pela juíza convocada Elvira Maria de Almeida Silva. julgamento em 7.1.2008.

TJ-SP, Representação Criminal n. 2121835-28.2017.8.26.0000. Rel. Sales Rossi. julgamento em 9.8.17.

TJSP. Apelação n. 10987112920148260100, Rel. Natan Zelinschi de Aruda, 02 fev. 2017.

TRF 4, Apelação criminal n. 2003.71.01.001894/RS. Rel. Des. Fed. Paulo Afonso Brum Vaz. Região. julgamento em 5.4.2006.

TRF 4, Habeas Corpus n. 2001.04.01.0855030-6/SC. Rel. Des. Fed. Vladimir Freitas. Região. julgamento em 19.2.2002.

TRF-03, Apelaçao Criminal n. 0012786-89.2010.4.03.6181/SP. Rel. Des. Fed. Paulo Fontes, $5^{\mathrm{a}}$ Turma. Julgamento em: 13.7.2015.

TRF-2, Recurso em Sentido Estrito 0000021-37.2015.4.02.5115 RJ, Rel. Messod Azulay Neto, $2^{\circ}$ Turma Especializada, julgamento em 14.12.2016. 


\section{LEGISLAÇÃO}

BRASIL. Constituição (1988). Constituição da República Federativa do Brasil. Brasília, DF, Senado, 1998.

BRASIL. Projeto de Lei n. 668, de 1988., de 14 de dezembro de 2017. Disponível em:

<http://mail.camara.rj.gov.br/APL/Legislativos/scpro1720.nsf/249cb321f17 965260325775900523a42/33fe5d166f161e70832581f6006be095?OpenDoc ument\&Start=1.1.1.5\&Highlight $=0,668 \% 2 F 2017>$. Acesso em: $14 \mathrm{fev}$. 2018.

\section{CONSULTAS DISPONÍVEIS NA INTERNET}

Disponível em: <http://g1.globo.com/sp/campinasregiao/noticia/2016/03/casos-de-violencia-contra-deficientes-crescem-34em-campinas-sp.html>. Acesso em: 10 abr. 2018.

Disponível em:

<http://violenciaedeficiencia.sedpcd.sp.gov.br/paginas/numeros.php>. Acesso em: 10 abr. 2018.

Disponível em: <http://g1.globo.com/Noticias/Brasil/0,,MUL12764375598,00-.html>. Acesso em: 02 mar. 2018

Disponível em: <https://grupogaydabahia.com.br/2015/01/13/assassinatode-lgbt-no-brasil-relatorio-2014>. Acesso em: 09 mai. 2018.

Disponível em:

<https://homofobiamata.files.wordpress.com/2014/03/relatc3b3riohomocidios-2013.pdf>. Acesso em: 09 mai. 2018.

Disponível em: <https://istoe.com.br/nova-era-do-odio-e-da-intolerancia/>. Acesso em: 09 mai. 2018.

Disponível em: <https://oglobo.globo.com/economia/envelhecimento-dapopulacao-acelera-cresce-16-em-4-anos-no-pais-22108208>. Acesso em: 09 abr. 2018.

Disponível em: <https://veja.abril.com.br/entretenimento/justica-condenagravadora-por-racismo-em-musica-de-tiririca/>. Acesso em: 28 fev. 2018. 
Disponível em: <https://www25.senado.leg.br/web/atividade/materias//materia/79604>. Acesso em: 11 mai. 2018.

Disponível em:

<http://colunas.revistaepoca.globo.com/guilhermefiuza/2013/06/06/aditadura-gay/>. Acesso em: 11 mai. 2018.

Disponível em: <http://veja.abril.com.br/blog/reinaldo/geral/o-ai-5gay-ja-comeca-a-satanizar-pessoas-seaprovado-vai-provocar-o-contrariodo-que-pretende-acabara-isolando-os-gays/>. Acesso em: 11 mai. 2018.

Disponível em: <http://veja.abril.com.br/noticia/brasil/falta-coragempara-enfrentar-a-ditadura-gay>. Acesso em: 11 mai. 2018.

Disponível em:

$<$ http://www.camara.leg.br/internet/sitaqweb/textoHTML.asp?etapa=11\&n uSessao=0963/13\&nu

Quarto $=0 \&$ nuOrador $=0 \&$ nuInsercao $=0 \&$ dtHorarioQuarto $=14: 00 \& \operatorname{sgFase} S$ essao $=\&$ Data $=10 / 7 / 20$

13\&txApelido=DIREITOS $\% 20$ HUMANOS $\% 20 \mathrm{E} \% 20 \mathrm{MINORIAS} \&$ txFase Sessao=Audi\%C3\%AAncia\%20P\%C3\%BAblica\%20Ordin\%C3\%A1ria\&t xTipoSessao $=\& d t H o r a Q u a r t o=14: 00 \&$ txEtapa $=>$. Acesso em: 11 mai. 2018.

Disponível em:

<https://brasil.elpais.com/brasil/2017/11/18/actualidad/1511039404_74260

0.html>. Acesso em: 09 mai. 2018.

Disponível em: <https://juizofinal.wordpress.com/2011/05/15/pl122por-que-somos-contra-a-essa-maldita-lei/> . Acesso em: 11 mai. 2018.

Disponível em:

<https://www25.senado.leg.br/web/atividade/materias/-/materia/106404>. Acesso em: 11 mai. 2018. 